SJ Quinney College of Law, University of Utah Utah Law Digital Commons

$10-2018$

\title{
The Trump Administration and Lessons Not Learned from Prior National Monument Modifications
}

John C. Ruple

S.J. Quinney College of Law, University of Utah, john.ruple@law.utah.edu

Follow this and additional works at: https://dc.law.utah.edu/scholarship

Part of the Environmental Law Commons

\section{Recommended Citation}

Ruple, John C., "The Trump Administration and Lessons Not Learned from Prior National Monument Modifications" (2018). Utah Law Faculty Scholarship. 136.

https://dc.law.utah.edu/scholarship/136 
** Pre-Publication Draft **

43 HARVARD ENVTL. L. REV. (2019)

\title{
The Trump Administration and Lessons Not Learned from Prior National Monument Modifications
}

\author{
John C. Ruple*
}

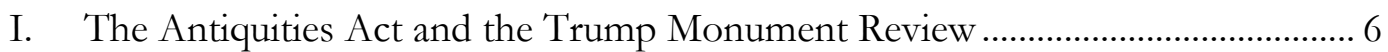

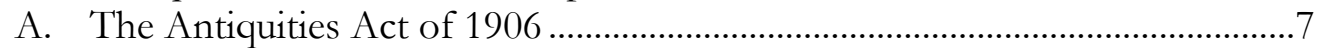

B. The Grand Staircase-Escalante National Monument....................................... 12

C. Bears Ears National Monument ……….............................................................. 16

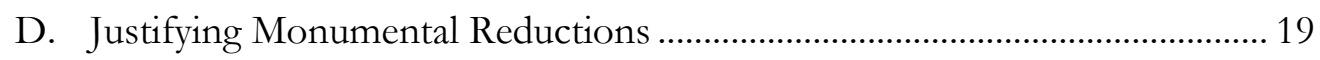

II. The President's Power to Reduce or Repeal a National Monument..................... 24

A. The Antiquities Act: To Promote Swift and Expansive Action .................... 26

B. Laws Authorizing Presidents to Revise Other Land Designations ............... 28

C. Bills Authorizing Presidents to Modify National Monument Proclamations

D. Executive Branch Understanding of Congressional Intent ............................ 34

E. The Power Implied by Congressional Acquiescence ........................................ 38

III. Prior Presidential National Monument Reductions and Revisions ...................... 42

A. Correcting Errors and Omissions in the Original Monument Proclamation

43

1. The Recurring Challenge of Public Land Surveys ..................................... 43

2. Problems Describing the Objects to be Protected and the Landscape

Containing Them ………........................................................................... 45

Navajo National Monument, Arizona........................................................ 46

Petrified Forest, Arizona...................................................................... 47

3. Inaccurate and Incomplete Surveys ............................................................... 49

Great Sand Dunes, Colorado ................................................................. 49

Hovenweep, Colorado and Utah............................................................... 50

Timpanogos Cave, Utah ........................................................................... 50

Mount Olympus, Washington.................................................................. 51

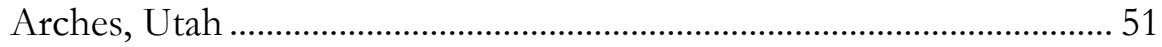

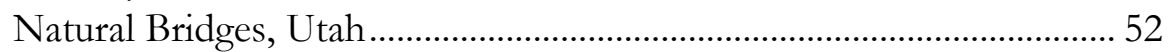

4. Inadvertent Inclusion of Non-Federal Land .............................................. 55

Black Canyon of the Gunnison, Colorado.............................................. 56

Mount Olympus, Washington..................................................................... 57

Glacier Bay, Alaska ................................................................................. 59

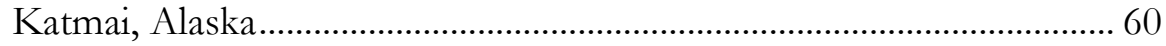




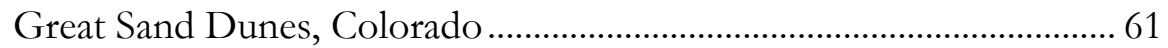

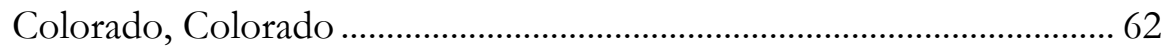

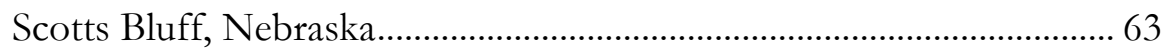

White Sands, New Mexico........................................................................... 64

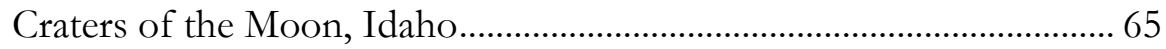

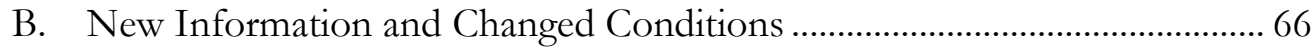

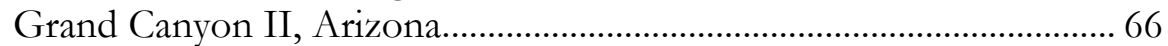

Wupatki, Arizona ………………............................................................. 72

C. National Monument Boundary Revisions Under the President's Article II

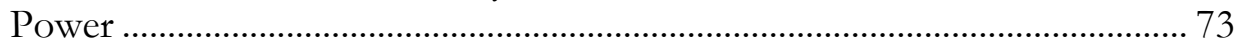

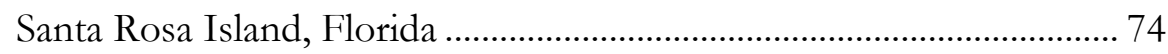

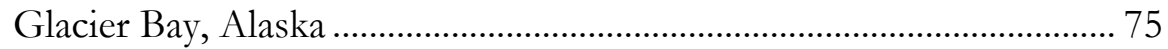

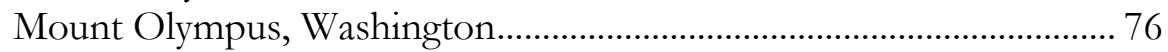

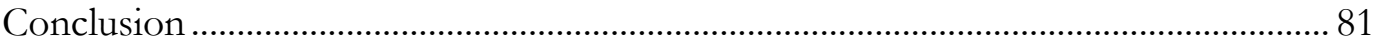

On December 4, 2017, President Trump issued a presidential proclamation that "modified and reduced" the 1.7-million-acre Grand Staircase-Escalante National Monument in Utah, carving the original monument, which was approximately the size of Delaware, into three smaller monuments. ${ }^{1}$ Together, the three smaller

* John C. Ruple is a Research Professor of Law and Wallace Stegner Center Fellow at the University of Utah's S.J. Quinney College of Law. He volunteers as a member of the board of directors for Friends of Cedar Mesa, which is challenging President Trump's reductions to the Bears Ears National Monument. Professor Ruple's views do not necessarily represent those of the state of Utah, the University of Utah, or Friends of Cedar Mesa. This paper was made possible by the generous support provided by the ESRR Endowment Fund, and the Wilburforce Foundation. Thank you to Professors Robert Keiter for your comments on early drafts of this paper. I am indebted to Professors Ross McPhail and Alicia Brillon, and to Research Assistants Connor Arrington, Caitlin Ceci, Michael Henderson, Brian House, and Merrill Williams. This paper would not have been possible without their assistance. Thank you to Pamela Baldwin who recently retired from the Congressional Research Service, and to the hard-working employees at the National Archives, National Park Service, and Department of Agriculture who helped unearth obscure source materials. Last but not least, thank you to the indomitable Tiffany Pett for her careful review and unwavering support.

1 Proclamation No. 9682, 82 Fed. Reg. 58,089 (Dec. 8, 2017) [hereinafter Grand StaircaseEscalante Modification Proc.]. 1.7 million acres reflects the size of the monument as originally designated. A subsequent land exchange with the state of Utah expanded federal land ownership by approximately 200,000 acres, Utah Schools and Land Exchange Act of 1998, Pub. L. No 105-335 (Oct. 31, 1998). 
** Pre-Publication Draft **

43 HARVARD ENVTL. L. REV. (2019)

monuments protect about half of the original monument's area. On the same day, President Trump "modified and reduced" the 1.3-million-acre Bears Ears National Monument, also in Utah, ${ }^{2}$ which President Obama had set aside less than a year earlier at the request of five Native American Tribes. ${ }^{3}$ Reductions to Bears Ears removed approximately eighty-five percent of the land from the original monument, replacing it with two smaller monuments. ${ }^{4}$ The President's actions, which reflect the two largest presidential reductions to a national monument that have ever been made, ${ }^{5}$ open lands excluded from the monuments to mineral exploration and development, reduce protection for resources within the replacement monuments, and diminish the role that Native Americans play in the management of Bears Ears.

President Trump's decision to drastically reduce the two monuments has spurred a vigorous and ongoing debate over the legality of his actions. ${ }^{6}$ The five Native American Tribes that had proposed Bears Ears, as well as multiple scientific, conservation, and environmental organizations, quickly sued to invalidate President Trump's reductions to Bears Ears. ${ }^{7}$ Scientific, conservation, and environmental organizations also immediately challenged the reductions to the Grand StaircaseEscalante National Monument. ${ }^{8}$ Others moved to intervene in support of the Trump

2 Proclamation No. 9681, 82 Fed. Reg. 58,081 (Dec. 8, 2017) [hereinafter Bears Ears Modification Proc.].

3 See Proclamation No. 9558, 82 Fed. Reg. 1139, 1143 (Dec. 28, 2016) [hereinafter Bears Ears Proc.]; Jonathan Thompson, Bears Ears a Go-But Here's Where Obama Drew the Line, HigH COUNTRY NEws (Dec. 29, 2016), https://perma.cc/2E46-KHGY.

4 See Bears Ears Modification Proc., supra note 2, at 58,084-85.

5 See Richard Gonzalez, Kirk Siegler \& Colin Dwyer, Trump Orders Largest National Monument Reduction in U.S. History, NPR (Dec. 4, 2017, 5:14 AM), https://perma.cc/G5P2-KAJ3.

${ }^{6}$ See Mark Squillace et al., Presidents Lack the Authority to Abolish or Diminish National Monuments, 103 VA. L. ReV. ONLINE 55 (2017); James R. Rasband, Stroke of the Pen, Law of the Land? 63 Rocky MTn. Min. L. Inst. \21-1 (2017); Pamela Baldwin, Presidential Authority to Modify or Revoke National Monuments (Sept. 17, 2017) (unpublished manuscript), available at https://perma.cc/YU7T-MHQF; Bruce Fein \& W. Bruce DelValle, Distorting the Antiquities Act to Aggrandize Executive Power-New Wine in Old Bottles (Nov. 30, 2017) (unpublished manuscript) (on file with author); Todd Gaziano \& John Yoo, Presidential Authority to Revoke or Reduce National Monument Designations, 35 YALE. J. REG. 617 (2018) https://perma.cc/L5AD-QNHH; Richard H. Seamon, Dismantling Monuments, 70 FLA. L. REV. 553 (2018).

7 See Complaint for Injunctive and Declaratory Relief, Hopi Tribe v. Trump, 1:17-cv-02590 (D.D.C. Dec. 4, 2017); Complaint for Declaratory and Injunctive Relief, Utah Diné Bikéyah v. Trump, 1:17-cv-02605 (D.D.C. Dec. 6, 2017); Complaint for Declaratory and Injunctive Relief, Nat. Res. Def. Council v. Trump, 1:17-cv-02606 (D.D.C. Dec. 7, 2017).

8 See Complaint for Injunctive and Declaratory Relief, Wilderness Soc'y v. Trump, 1:17-cv-02587 
** Pre-Publication Draft **

43 HARVARD ENVTL. L. REV. (2019)

administration, ${ }^{9}$ setting up a battle over presidential power that appears destined for the Supreme Court.

Before President Trump acted, it had been fifty-five years since a President last removed land from a national monument. ${ }^{10}$ Every national monument that was previously reduced by presidential action involved a monument that had been set aside before 1940, and most at least a decade sooner, at a time when information about both the objects to be protected by the monument and the landscape those objects occupied was often limited and imprecise. The President's legal authority for these prior monument reductions was never tested in court.

The plaintiffs contend that the Constitution reserves to Congress the power over our public lands, and with it, the power to revise national monuments. ${ }^{11}$ While Congress authorized a President to create national monuments when it enacted the Antiquities Act of 1906, ${ }^{12}$ Congress had no reason to delegate away the power to revise those monuments. To now endow a President with such far reaching powers absent clear congressional intent, they contend, would both upset the balance of power between the legislative and executive branches, and create a cloud of uncertainty over the future of long-protected lands-neither of which Congress could have reasonably intended. The plaintiffs also argue that sweeping public land law reforms enacted in 1976 evidence Congress' desire to rein in the President's assertion of power over the public lands.

President Trump, in reducing the monuments, argues that some of the objects identified in the original monument proclamations are not "unique to the monument[s], and some of the particular examples of these objects within the monument $[\mathrm{s}]$ are not of significant scientific or historic interest." ${ }^{\prime 3}$ Other objects are not under threat or are adequately protected by other laws. ${ }^{14}$ The original monuments were, in President Trump's eyes, not confined to the smallest area necessary to protect monument resources. The President's supporters correctly note

(D.D.C. Dec. 4, 2017); Complaint for Declaratory and Injunctive Relief, Grand Staircase Escalante Partners v. Trump, 1:17-cv-02591 (D.D.C. Dec. 4, 2017).

9 See Defendant-Intervenor's Motion to Intervene, Utah Diné Bikéyah v. Trump, 1:17-cv-02605 (D. D.C. Jan. 11, 2018).

10 Proclamation No. 3486, 76 Stat. 1495 (Aug. 14, 1962) [hereinafter 1962 Natural Bridges Revision Proc.]

11 See e.g., Complaint for Injunctive and Declaratory Relief, Hopi Tribe v. Trump, supra note 7 at 1. Substantially the same argument is made in all three complaints.

1254 U.S.C. SS 320101-303 (2012).

13 Bears Ears Modification Proc., supra note 3, at 58,081-82.

${ }^{14} \mathrm{Id}$. 
** Pre-Publication Draft **

43 HARVARD ENVTL. L. REV. (2019)

that in passing the Antiquities Act, Congress did not expressly deny the President the power to revise monument boundaries. They then contend that the explicit grant of power to create national monuments should include an implicit grant of authority to revisit and revise prior decisions anytime a President sees fit. They go on to argue that in light of ambiguous statutory language, courts should look to congressional acquiescence in close to two dozen prior presidential reductions to national monuments. Doing so, they assert, evidences congressional intent to endow the President with the power to revise or repeal a national monument.

In the debate surrounding President Trump's monument reductions, a critical and as-yet-unanswered question is whether prior presidential monument reductions create a precedent for contemporary actions through the doctrine of congressional acquiescence. This article undertakes a historical survey of prior presidential reductions to determine whether - and if so to what extent - there is a pattern of presidential action sufficient to support the congressional acquiescence argument. I find that the historical record does not support the argument that Congress acquiesced to reductions by proclamation generally. Most prior reductions were small in size, and many if not most, likely occurred without Congressional notice. Congress repeatedly voted down bills to grant Presidents the authority to reduce monuments, and more than fifty years has passed since the last presidential reduction to a monument. During the intervening decades Congress expressly constrained the executive branch's discretionary power over public lands. Past reductions, moreover, can be classified either as minor boundary adjustments to early monuments that were designated on unsurveyed lands, revisions intended to improve resource protection rather than to accommodate commodity production, or as adjustments made under the President's Article II war powers in relation to the two World Wars. President Trump's reductions, which are the largest in history, therefore lack the historical precedent needed to support congressional acquiescence.

Section I introduces the Antiquities Act and the Bears Ears and Grand Staircase-Escalante national monuments. Section II discusses arguments for and against the President's authority to reduce national monuments. Section III analyzes prior monument reduction, finding no precedent for President Trump's recent actions. The article then concludes that while Congress appeared intent on reserving broad discretion to revise national monuments for itself, a case can be made that in the past, Congress may have acquiesced in a President's actions to update national monument boundaries. But even if acquiescence occurred, prior acquiescence involved justifications that have little connection to reductions to Bears Ears or the Grand Staircase-Escalante national monuments. President Trump's monumental 
reductions stand alone, lacking the precedential support needed to demonstrate congressional acquiescence in an assumption of congressional power.

\section{The Antiquities Act and the Trump Monument Review}

On April 26, 2017, President Trump directed Secretary of the Interior Ryan Zinke to review certain designations and expansions of prior national monuments for compliance with the Antiquities Act of 1906 and for conformity with administration policy. ${ }^{15}$ Each of the twenty-seven monuments subject to review under the President's order was designated after January 1, 1996, and chosen for review either because it exceeded 100,000 acres in size, or, in the Secretary's opinion, had been set aside without adequate public input. ${ }^{16}$ After review, Secretary Zinke recommended boundary reductions and management changes for six national monuments, and management changes to four additional monuments. ${ }^{17} \mathrm{On}$ December 4, 2017, President Trump reduced two of the monuments identified in Secretary Zinke's report: Bears Ears and Grand Staircase-Escalante. ${ }^{18}$ As of the writing of this paper, no action has been taken on the other monuments recommended for management changes or reduction. ${ }^{19}$

This section reviews the statute authorizing a President to designate a national monument, describes the two monuments that were reduced by President

${ }^{15}$ Exec. Order No. 13792, 82 Fed. Reg. $20429 \$ 2$ (Apr. 26, 2017).

${ }^{16} \mathrm{Id}$.

${ }^{17}$ Memorandum from Ryan Zinke, Sec'y of the Interior, to the President, Final Report Summarizing Findings of the Review of Designations Under the Antiquities Act [hereinafter Memo from Secretary Zinke], https://perma.cc/JZQ3-MA3Y.

${ }^{18}$ Grand Staircase-Escalante Modification Proc., supra note Error! Bookmark not defined.; Bears Ears Modification Proc., supra note 2.

${ }^{19}$ On April 28, 2017, President Trump also directed the Secretary of Commerce to review eleven National Marine Sanctuaries and Marine National Monuments designated pursuant to the Antiquities Act during the preceding ten-year period. Exec. Order No. 13795, 82 Fed. Reg. 20,815 \4(b) (May 3, 2017). This review assesses the acreage impacted by these designations; the cost of managing the designations; the adequacy of consultation with federal, state, and tribal entities prior to designation; and "the opportunity costs associated with potential energy and mineral exploration and production from the Outer Continental Shelf, in addition to any impacts on production in the adjacent region." Id. at $₫ 4(\mathrm{~b})(\mathrm{i})$. The Secretary of Commerce was not directed to assess Antiquities Act compliance with respect to these sanctuaries and monuments. The results of this review were due to the President on October 5, 2017 and have not been released to the public. The President has not taken action based on those recommendations as of the writing of this paper. 
** Pre-Publication Draft **

43 HARVARD ENVTL. L. REV. (2019)

Trump, and then briefly addresses the protections afforded to the objects identified in a national monument proclamation.

\section{A. The Antiquities Act of 1906}

Congress enacted the Antiquities Act of $1906^{20}$ largely in response to concerns over looting and desecration of Native American sites in the Southwestern United States. ${ }^{21}$ In passing the Antiquities Act, Congress delegated to the President the unilateral and discretionary authority to:

[D]eclare by public proclamation historic landmarks, historic and prehistoric structures, and other objects of historic or scientific interest that are situated on land owned or controlled by the Federal Government to be national monuments. ... The limits of the parcels shall be confined to the smallest area compatible with the proper care and management of the objects to be protected. ${ }^{22}$

Since 1906, Presidents have relied on this authority to designate 157 national monuments, which are spread across thirty-two states, the District of Columbia, and several U.S. territories. ${ }^{23}$ Sixteen Presidents, Republicans and Democrats alike, have utilized this authority. ${ }^{24}$ Some of our most iconic national parks began as national monuments, including the Grand Canyon in Arizona, Arches in Utah, Olympic in

2054 U.S.C. SS 320101-303 (2012).

21 See Mark Squillace, The Monumental Legacy of the Antiquities Act of 1906, 37 GA. L. REV. 473, 47778 (2003); Robert B. Collins \& Dee F. Green, A Proposal to Modernize the American Antiquities Act, 202 SCIENCE 1055, 1055 (1978).

2254 U.S.C. $\iint 320301(\mathrm{a})$ and (b).

${ }^{23}$ National Park Service, Dept. of the Interior, Antiquities Act 1906-2006: Monuments List www.nps.gov/archeology/sites/antiquities/monumentslist.htm last updated Oct. 21, 2018. See also, National Park Service, Dept. of the Interior, List of Acreage (Summary) (Dec. 31, 2017) https://irma.nps.gov/Stats/FileDownload/11403; National Parks Conservation Ass'n, Antiquities Act Designations and Related Actions (no date) (on file with author). Accurately calculating the acreage of early national monuments was problematic because of incomplete and inaccurate surveys. This resulted in inconsistent reports of monument size between various sources. Where acreage calculations depart, this article cites first to monument proclamations, then to National Park Service Statistics, and then to information provided by the National Parks Conservation Association.

${ }^{24}$ Id. 
** Pre-Publication Draft **

43 HARVARD ENVTL. L. REV. (2019)

Washington State, Acadia in Maine, and Grand Teton in Wyoming. ${ }^{25}$

The two key requirements of the Act-that monuments be set aside to protect "objects of historic or scientific interest," and that monuments be "confined to the smallest area compatible with the proper care and management of the objects to be protected"- - have both been construed broadly by the courts.

In 1920, the U.S. Supreme Court upheld presidential designation of the Grand Canyon National Monument. ${ }^{26}$ President Roosevelt had set aside the 808,120acre monument ${ }^{27}$ twelve years earlier to protect "the greatest eroded canyon within the United States." ${ }^{28}$ Ralph Cameron, a local miner who would go on to represent Arizona in the United States Senate, disputed the designation. The United States sued to enjoin Mr. Cameron from interfering with public use of lands within the newly-minted Monument. Mr. Cameron initially argued that the canyon was "not an historic landmark, nor an historic or prehistoric structure nor an object of historic or scientific interest nor an antiquity in the sense intended and contemplated by Congress," and that because of its size, "the limits of the said pretended monument are not confined to the smallest area compatible with the proper care and management of the canyon. ${ }^{\prime 29}$ Both the District Court and Court of Appeals held for the government. ${ }^{30}$ The Supreme Court also held otherwise, concluding that the Antiquities Act empowered the President "to establish reserves embracing 'objects of historic or scientific interest," 31 and that the Grand Canyon:

"is an object of unusual scientific interest." It is the greatest eroded canyon in the United States, if not in the world, is over a mile in depth, has attracted wide attention among explorers and scientists, affords an unexampled field for geologic study, [and] is regarded as one of the great natural wonders. ${ }^{32}$

Fifty-six years later, in the only other challenge to the Antiquities Act to reach the Supreme Court, the Court again gave "objects of historic or scientific

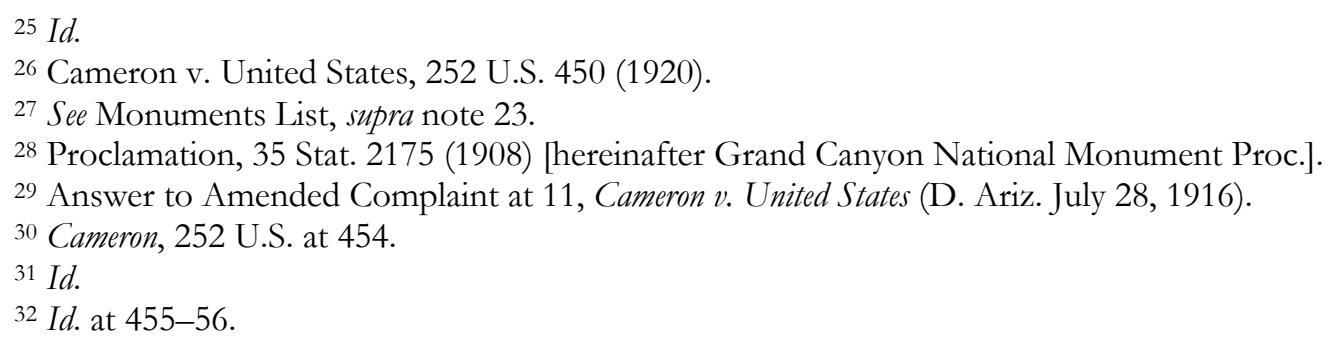


** Pre-Publication Draft **

43 HARVARD ENVTL. L. REV. (2019)

interest" a broad reading, concluding that an endemic fish species and the pool it inhabited in the Death Valley National Monument in California were objects of historic or scientific interest within the meaning of the Antiquities Act. ${ }^{33}$ In 2002, the D.C. Circuit Court of Appeals similarly held that "ecosystems and scenic vistas" are appropriate objects for protection under the Antiquities Act. ${ }^{34}$ Indeed no challenge to a national monument designation has ever prevailed in court. ${ }^{35}$

In the most recent challenge to a national monument, Massachusetts Lobstermen's Association v. Ross, ${ }^{36}$ the District Court held that the Antiquities Act includes the power to designate monuments on submerged ocean lands. ${ }^{37}$ More germane to the challenge to the Trump Administration's monument reductions, the court also held that review of the decision to create national monuments "would be available only if the plaintiff were to offer plausible and detailed factual allegations that the President acted beyond the boundaries of authority that Congress set." 38 That is precisely the question raised by Bears Ears and Grand Staircase-Escalante national monument litigation.

The Antiquities Act authorizes the President to "reserve parcels of land as part of the national monuments." 39 Relying on this authority, national monument proclamations invariably withdraw lands within a monument from availability for disposal or future mineral development. ${ }^{40}$ Monument proclamations also frequently specify other protections, like limitations on construction of new roads, that are intended to protect monument resources. ${ }^{41}$ More specific management requirements

33 Cappaert v. United States, 426 U.S. 128, 142 (1976).

34 Tulare Cty. v. Bush, 306 F.3d 1138, 1142 (D.C. Cir. 2002).

35 See, e.g., Cameron, 252 U.S. 450 (Grand Canyon); Cappaert, 426 U.S. 128 (Devil's Hole); Tulare Cty., 185 F. Supp. 2d 18, 27 \& n.2 (D.D.C. 2001), aff'd, 306 F.3d 1138 (D.C. Cir. 2002) (Giant Sequoia); Mass. Lobstermen's Assoc. v. Ross, 2018 WL 4853901 (D.D.C. Oct. 5, 2018); Utah Ass'n of Ctys. v. Bush, 316 F. Supp. 2d 1172 (D. Utah 2004), appeal dismissed for lack of standing, 455 F.3d 1094 (10th Cir. 2006) (Grand Staircase-Escalante); Anaconda Copper Co. v. Andrus, No. A79-161 Civil, 1980 U.S. Dist. LEXIS 17861 (D. Alaska July 1, 1980) (several Alaskan national monuments); Alaska v. Carter, 462 F. Supp. 1155 (D. Alaska 1978) (several Alaskan national monuments); Wyoming v. Franke, 58 F. Supp. 890 (D. Wyo. 1945) (Jackson Hole).

362018 WL 4853901 (D.D.C. Oct. 5, 2018).

37 Id. at $* 8$.

38 Id. at $* 4$.

3954 U.S.C. \ $320301(\mathrm{~b})$.

40 See, e.g., Bears Ears Proc., supra note 3, at 1143; Proclamation No. 6920, 61 Fed. Reg. 50223, 50225 (Sept. 18, 1996) [hereinafter Grand Staircase-Escalante Proc.].

41 See, e.g., Bears Ears Proc., supra note 3 at 1145. 
** Pre-Publication Draft **

43 HARVARD ENVTL. L. REV. (2019)

are developed through a planning process that normally begins shortly after monument designation. ${ }^{42}$

The Grand Staircase-Escalante National Monument is managed by the Bureau of Land Management (BLM), and Bears Ears is co-managed by the BLM and U.S. Forest Service. Additional protections for the objects and lands in a national monument that are managed by the BLM occur by virtue of a monument's inclusion in the National Landscape Conservation System (NLCS). ${ }^{43}$ In 2009, Congress established the NLCS to "conserve, protect, and restore nationally significant [BLM managed] landscapes that have outstanding cultural, ecological, and scientific values for the benefit of current and future generations." 44 National monuments were designated part of the NLCS. ${ }^{45}$ In managing the NLCS, the "Secretary [of the Interior] shall manage the system . . . in a manner that protects the values for which the components of the system were designated." 46 Therefore even if a monument proclamation does not expressly preclude certain activities, the Secretary can authorize those actions only if they do not harm monument resources. This places a thumb on the multiple use management scale, guaranteeing that protection of the objects identified in the monument proclamation is the primary management objective. This conservation emphasis disappears when BLM lands are eliminated from a monument and returned to multiple use, sustained yield management as set forth in the Federal Land Policy and Management Act of $1976 .{ }^{47}$ The mineral withdrawals that accompany monument proclamations also disappear when lands are excluded from a monument.

The breadth of authority granted in the Antiquities Act and affirmed by the courts affords Presidents extraordinary latitude to incorporate place-specific language in national monument proclamations. President Obama, for example, recognized

\footnotetext{
42 See, e.g., id. at 1143-44. Where national monument management plans already exist, changes in management requirements applicable to lands excluded from a monument may require an update to management plans and an environmental review before they can take effect, but this issue is beyond the scope of the current paper.

43 The NLCS has been renamed the National Conservation Lands System. Because the statute creating the National Conservation Lands System has not been amended to reflect the change in terminology, this paper retains the older terminology to avoid confusion.

4416 U.S.C. $\$ 7202(a)$.

${ }^{45} \mathrm{Id}$. at $\$ 7202(\mathrm{~b})(1)(\mathrm{A})$.

${ }^{46} \mathrm{Id}$. at $\$ 7202(\mathrm{c}),(\mathrm{c})(2)$.

4743 U.S.C. $\$ 1701(\mathrm{a})(7)$.
} 
** Pre-Publication Draft **

43 HARVARD ENVTL. L. REV. (2019)

state primacy in water rights permitting ${ }^{48}$ and wildlife management. ${ }^{49} \mathrm{He}$ also recognized the importance of maintaining existing infrastructure ${ }^{50}$ and continuing ongoing livestock grazing. ${ }^{51}$ Recent national monument proclamations also invariably require managers to create a management plan in consultation with state, local, and tribal governments, ensuring that those closest to the land have a voice in how that land is managed. ${ }^{52}$ Language specifically protecting Native Americans' rights to access and use national monuments is included in all Obama-era proclamations involving significant public land acreage. ${ }^{53}$ Recent monument proclamations also specifically address Native American use of forest products, firewood, and medicinal plants, where those issues have regional significance. ${ }^{54}$ Unless provided for by other

48 See, e.g., Proclamation No. 9297, 80 Fed. Reg. 41969, 41973 (July 10, 2015) [hereinafter Basin and Range Proc.].

49 See, e.g., Proclamation No. 9232, 80 Fed. Reg. 9975, 9979 (Feb. 24, 2015) [hereinafter Browns Canyon Proc.).

50 See, e.g., Proclamation No. 8946, 78 Fed. Reg. 18,783, 18785 (Mar. 25, 2013) [hereinafter Río Grande Del Norte Proc.] (protecting utility line rights-of-way within the monument). See also, Proclamation No. 9559, 82 Fed. Reg. 1149, 1152 (Jan. 5, 2017) [hereinafter Gold Butte Proc.] (authorizing "operation, maintenance, replacement, modification, or upgrade" of utilities).

51 See, e.g., Bears Ears Proc., supra note 3, at 1145 ("Laws, regulations, and policies followed ... in issuing and administering grazing permits or leases on lands under their jurisdiction shall continue to apply.").

52 See, e.g., Proclamation No. 9298, 80 Fed. Reg. 41,975, 41,979 (July 10, 2015) [hereinafter Berryessa Snow Mountain Proc.] (providing for "public involvement in the development of the management plan including, but not limited to, consultation with tribal, State, and local governments.").

53 See, e.g., Proclamation No. 9476, 81 Fed. Reg. 59,121, 59,127 (Aug. 24, 2016) [hereinafter Katahdin Woods and Waters National Monument Proc.] ("The Secretary shall, to the maximum extent permitted by law and in consultation with Indian tribes, ensure the protection of Indian sacred sites and cultural sites in the monument and provide access to the sites by members of Indian tribes for traditional cultural and customary uses."). A number of other proclamations contain substantively identical language. See Gold Butte Proc., supra note 50, at 1153; Bears Ears Proc., supra note 3, at 1145; Proclamation No. 9396, 81 Fed. Reg. 8379, 8383 (Feb. 12, 2016) [hereinafter Sand and Snow Proc.]; Proclamation No. 9395, 81 Fed. Reg. 8371, 8375 (Feb. 12, 2016) [hereinafter Mojave Trails Proc.]; Proclamation No. 9394, 81 Fed. Reg. 8365, 8367 (Feb. 12, 2016) [hereinafter Castle Mountains Proc.]; Berryessa Snow Mountain Proc., supra note 52, at 41979; Basin and Range Proc., supra note 48, at 41972-73; Browns Canyon Proc., supra note 49 at 9979; Proclamation No. 9131, 79 Fed. Reg. 30,431, 30,435 (May 21, 2014) [hereinafter Organ Mountains-Desert Peaks]; Proclamation No. 8947, 78 Fed. Reg. 18,789, 18,791 (Mar. 25, 2013) (San Juan Islands Proc.).

54 Proclamation No. 9194, 79 Fed. Reg. 62,303, 62,306 (Oct. 10, 2014) [hereinafter San Gabriel 
** Pre-Publication Draft **

43 HARVARD ENVTL. L. REV. (2019)

laws, these directives also fall away when a monument is undone.

\section{B. The Grand Staircase-Escalante National Monument}

On September 18, 1996, President Clinton designated the 1.7-million-acre Grand Staircase-Escalante National Monument to protect a "spectacular array" of sensitive scientific, historic, prehistoric, archaeological, paleontological, cultural, and natural resources. ${ }^{55}$ The proclamation also withdrew lands within the monument from mineral development or disposal. ${ }^{56}$ President Clinton described the monument, which was the last place in the continental United States to be mapped, as an unspoiled frontier and a "geologic treasure" teeming with "world class paleontological sites," a place "rich in human history," and containing "an extraordinary number of areas of relict vegetation, many of which have existed since the Pleistocene." 57 Indeed, the monument has produced discoveries of over fortyfive new paleontological species, including twelve new species of dinosaurs. ${ }^{58}$

The Grand Staircase-Escalante was the first national monument to be managed by the BLM. Previously, when monuments were proclaimed on BLM-

Mountains Proc.] (guaranteeing monument access for "traditional cultural, spiritual, and tree and forest product-, food-, and medicine-gathering purposes"); Río Grande Del Norte Proc., supra note 50, at 18,785-86 ("ensur[ing] the protection of religious and cultural sites in the monument and provide access to the sites by members of Indian tribes for traditional cultural and customary uses [and] traditional collection of firewood and piñon nuts in the monument for personal non-commercial use consistent with the purposes of this proclamation"); Proclamation No. 8868, 77 Fed. Reg. 59,275, 59,277 (Sept. 21, 2012) [hereinafter Chimney Rock Proc.] (to "protect and preserve access by tribal members for traditional cultural, spiritual, and food- and medicine-gathering purposes, consistent with the purposes of the monument, to the maximum extent permitted by law").

55 Grand Staircase-Escalante Proc., supra note 40, at 50,223.

${ }^{56} \mathrm{Id}$. at 50,225. Public lands were commonly disposed of via grants to states, railroads, homesteaders, miners, returned military veterans, and others. For a background on public land disposal laws, see Paul W. Gates, Public Land Law Review Commission, History of Public Land Law DeVelopment (1968).

${ }^{57} \mathrm{Id}$. at $50,223-24$.

58 See Jeffrey G. Eaton \& Richard L. Cifelli, Review of Late Cretaceous Mammalian Faunas of the Kaiparowits and Paunsaugunt Plateaus, Southwestern Utah, in AT THE TOP OF THE GRAND StAircase: The Late Cretaceous of Southern UtAh 319-28 (Alan L. Titus \& Mark A. Loewen eds., 2013). See also, Alan L. Titus, Jeffrey G. Eaton \& Joseph Sertich, Late Cretaceous Stratigraphy and Vertebrate Faunas of the Markagunt, Paunsaugunt, and Kaiparowits Plateaus, Southern Utah, 3 GEOLOGY OF THE INTERMOUNTAIN WEST 229, 229-91 (2016), available at https://perma.cc/EUX6-RG2R. 
** Pre-Publication Draft **

43 HARVARD ENVTL. L. REV. (2019)

managed lands, monument administration was turned over to the National Park Service. ${ }^{59}$ In keeping management of the Grand Staircase-Escalante with the BLM, President Clinton sent a clear message to the BLM that conservation was an important part of the agency's mission, offering it "a highly visible opportunity to demonstrate its stewardship." ${ }^{\circ 0}$ Retaining BLM management also attempted to send a message to rural residents that the administration had heard their concerns and that monument management would be less restrictive than might have occurred had management been turned over to the National Park Service. ${ }^{61}$

Monument designation was received favorably by environmental groups, who "view[ed] it as an important step forward in permanently protecting southern Utah's vulnerable landscapes." ${ }^{\prime 2}$ State and local politicians, on the other hand, "uniformly condemned the decision, labeling it a land grab, crass political opportunism, and much worse." ${ }^{63}$ These criticisms resulted from the perceived lack of state input in the designation, ${ }^{64}$ and the economically valuable mineral resources that were made unavailable for development as a result of the designation. ${ }^{65}$

The Monument also surrounded approximately 200,000 acres of state trust lands ${ }^{66}$ - lands that are managed to generate revenue in support of public schools

${ }^{59}$ Capitol Reef National Monument in Utah, for example, was originally set aside out of public lands, and the National Park Service was charged with monument management. Proclamation No. 2246, 50 Stat. 1856 (August 2, 1937). On Dec. 18, 1971 Congress elevated the monument to National Park status. Pub. L. No. 92-207, 85 Stat. 739 (1971).

${ }^{60}$ Memorandum from Sec. of the Interior Bruce Babbitt to BLM Director re: Management of Grand Staircase-Escalante National Monument 1 (Nov. 6, 1996) (on file with author).

61 "Part of the idea of a BLM monument is that it is somewhat different from a park; in part because it allows hunting and tolerates some other uses you may not tolerate in a Park." Transcript of Utah State Historical Society Oral History Program Interview with John D. Leshy 12 (April 1, 2014) (on file with author).

62 Robert B. Keiter, The Monument, The Plan, and Beyond, 21 J. LAND, RES. \& ENVTL. L. 521, 524 25 (2001).

${ }^{63} \mathrm{Id}$.

64 See, e.g., Joe Judd, County Collaboration with the BLM on the Monument Plan and its Roads, $21 \mathrm{~J}$. LAND, RES. \& ENVTL. L. 553 (2001). But the Solicitor for the Department of the Interior recounts meeting with members of the Utah congressional delegation in advance of the designation to incorporate their concerns into the proclamation. See Utah State Historical Society Oral History Program Interview with John Leshy, former Solicitor, U.S. Dep't of Interior, (July 7, 2014) (on file with author).

65 Janice Fried, The Grand Staircase-Escalante National Monument: A Case Study in Western Land Management, 17 VA. ENVTL. L.J. 477, 489 (1998).

66 Albert C. Lin, Clinton's National Monuments: A Democrat's Undemocratic Acts?, 29 ECOLOGY LAW 
** Pre-Publication Draft **

43 HARVARD ENVTL. L. REV. (2019)

and institutions ${ }^{67}$ - and that many locals looked to with a hope of jobs to come. Those opposed to the designation noted that some believed the Monument to contain sixty-two billion tons of coal, between three and five billion barrels of oil, and two to four trillion cubic feet of natural gas, ${ }^{68}$ estimated to be worth between "tens to hundreds of billions of dollars." 69

Recognizing that monument designation made development of state trust land inholdings more difficult, President Clinton stated that the Monument "should not and will not come at the expense of Utah's school children," and directed the federal government to promptly respond to a request to trade state lands within the monument for federal lands outside of the monument that were more appropriate for development. ${ }^{70}$ President Clinton also directed the Secretary of the Interior to resolve "reasonable doubts" as to land value in favor of Utah's trust lands. ${ }^{71}$ Barely eighteen months later, the Secretary of the Interior and the Governor of Utah agreed to such an exchange. ${ }^{72}$ Enacted into law on October 31, 1998, the Utah Schools and Land Exchange $\mathrm{Act}^{73}$ authorized the largest land exchange in the history of the lower forty-eight states. ${ }^{74}$ Utah conveyed to the federal government 376,739 acres of school trust lands both inside and outside of the Monument in return for $\$ 50$ million in cash, the right to $\$ 13$ million in potential future coal rents and royalties; 138,647 acres of federal land; and mineral rights to roughly 160 million tons of coal and 185 billion cubic feet of coal bed methane. ${ }^{75}$

QUARTERLY 707, 723 (2002).

${ }^{67}$ Utah Code Ann. \53C-1-102 (West 2018); see also Nat. Parks Conservation Ass'n v. Bd. of State Lands, 869 P.2d 909, 916-17 (Utah 1994).

${ }^{68}$ Janice Fried, supra note 65, at 489. (1998).

${ }^{69} \mathrm{Id}$.

${ }^{70}$ President William J. Clinton, Remarks Announcing the Establishment of the Grand StaircaseEscalante National Monument at Grand Canyon National Park, Arizona, in 32 WeEKLY COMP. PRES. Doc. 1785, 1787 (Sept. 18, 1996).

${ }^{71}$ John W. Andrews, Swapping With the Feds: An Updated Look at Federal Land Exchanges, 51 RoCKY MTN. Min. L. INST. \8.03[2] (2004).

72 An argument can be made that the congressionally authorized land exchange, the resulting boundary adjustment, and a second congressional boundary revision ratified President Clinton's designation, converting a presidential action into a congressional action that could only be undone by Congress. Squillace, supra note 21 at 550-51. This argument, however, is beyond the scope of this paper and left for another day.

73 Pub L. No. 105-335, 112 Stat. 3139 (1998).

${ }^{74}$ President William J. Clinton, Statement on Signing the Utah Schools and Land Exchange Act of 1998, 1998 U.S.C.C.A.N. 715 (Oct. 31, 1998).

${ }^{75}$ H.R. Rep. 105-598, at 4 (1998). 
** Pre-Publication Draft **

43 HARVARD ENVTL. L. REV. (2019)

In much of Utah, the Grand Staircase-Escalante National Monument remained a source of deep resentment regarding management decisions by federal agencies, and when Donald J. Trump was elected President, Utah's political establishment aggressively lobbied the new President to greatly reduce the Monument. ${ }^{76}$ President Trump heeded those requests, and on December 4, 2017, signed a Presidential Proclamation carving the Monument into three smaller units that together encompass little more than half the area protected by President Clinton twenty-one years earlier. ${ }^{77}$

In addition to reducing the Monument by 876,598 acres, President Trump's proclamation dramatically changed management of this Monument. The 1996 proclamation creating the Monument withdrew all federal lands within its boundary from availability for future mineral leasing or mining claims. ${ }^{78}$ The 2017 proclamation made "the public lands excluded from the monument reservation ... open to: (1) entry, location, selection, sale or other disposition under the public land laws; (2) disposition under all laws relating to mineral and geothermal leasing; and (3) location, entry, and patent under the mining laws." 79

According to science and conservation interests, the 2017 Monument reduction leaves valuable paleontological resources unprotected.

At least 700 scientifically important fossil sites have been excluded by the new monument boundaries. ... Most of the formations containing fossils from the Cenomanian through Santonian ages have been excluded. The Dakota (also known as Naturita) and Tropic Shale Formations have been almost entirely excluded, and parts of the Wahweap Formation have been excluded, including the site where the unique horned dinosaur Machairoceratops was discovered, where the only known specimen of a new species of nodosaur was discovered, and where there is a major hadrosaur bonebed. The Tropic Shale is one of the only fully marine geological units in the

\footnotetext{
76 See Darryl Fears, Bears Ears is a National Monument Now. But it will Take a Fight to Save it. Utab's GOP leaders want to rescind Bears Ears, and they have President Trump's Ear, WASHINGTON POST, March 22, 2017, 2017 WLNR 8892542.

77 See Grand Staircase-Escalante Modification Proc., supra note Error! Bookmark not defined., at 58,093 .

${ }^{78}$ Grand Staircase-Escalante Proc., supra note 40, at 50,225.

${ }^{79}$ Grand Staircase-Escalante Modification Proc., supra note Error! Bookmark not defined., at 58,093.
} 
** Pre-Publication Draft **

43 HARVARD ENVTL. L. REV. (2019)

Monument-from when this region was covered by water eons ago-and is part of the Late Cretaceous sequence of ecosystems referred to in the 1996 Proclamation. Large portions of the petrified forest referred to in the 1996 Proclamation have been excluded.

All of the Naturita (Dakota) Formation mammal localities from Bulldog Bench outside of Cannonville have been removed from the Monument. Outside of Henrieville, the Smoky Hollow Member of the Straight Cliffs, a premier microvertebrate locality (site with tiny fossils that represent small and often rare species) has been eliminated from the Monument. The "type" area of the Kaibab Limestone geological unit-where the defining characteristics of the bed are studied in a particular location and then used to trace the bed over sometimes large distances-is excluded by the new boundaries. ${ }^{80}$

As David Polly, President of the Society of Vertebrate Paleontologists explains, "[t]he rock layers of the monument are like pages in an ancient book. If half of them are ripped out, the plot is lost." 11

\section{Bears Ears National Monument}

On December 28, 2016, President Obama designated the Bears Ears National Monument in southeastern Utah. President Obama poetically described the twin buttes for which the monument was named and "the surrounding deep sandstone canyons, desert mesas, and meadow mountaintops, which constitute one of the densest and most significant cultural landscapes in the United States." 82 As the President explained, "[f]rom earth to sky, the region is unsurpassed in wonders." ${ }^{\prime 3} \mathrm{It}$ is "vibrant . . . diverse . . . and ruggedly beautiful," — home to "stunning geology, from sharp pinnacles to broad mesas, labyrinthine canyons to solitary hoodoos, and verdant hanging gardens to bare stone arches and natural bridges." ${ }^{84}$ It is also a

\footnotetext{
80 Memorandum in Support of Plaintiffs' Motion for Partial Summary Judgement at 16, Grand Staircase Escalante Partners v. Trump, No. 1:17-CV-02591-TSC (D.D.C. Jan. 20, 2018).

81 Tay Wiles, Monument Reductions Threaten Future Dinosaur Discoveries, High CounTRY News, Jan. 30, 2018, https://perma.cc/3MBZ-MEWD (quoting David Polly, President, Society of Vertebrate Paleontologists).

82 Bears Ears Proc., supra note 3, at 1139.

83 Id. at 1141.

${ }^{84} \mathrm{Id}$. at $1139-40$.
} 
** Pre-Publication Draft **

43 HARVARD ENVTL. L. REV. (2019)

landscape that is "profoundly sacred to many Native American tribes." 85

Proposals to create a national park or national monument that would have included the Bears Ears area date to at least $1935 .{ }^{86}$ Near the beginning of the Obama Administration, a memorandum identifying Cedar Mesa, which is the heart of the Bears Ears area, as a potential national monument was leaked to the press. This generated fierce opposition from Utah's governor and congressional delegation. ${ }^{87}$ Opposition to the potential monument and the development restrictions that it could entail inspired the Utah congressional delegation to develop their own land management plan, using proposed protective designations as "currency" to secure guarantees that other areas would be open for commodity development. ${ }^{88}$ While Native Americans initially sought to collaborate in the "Public Lands Initiative," (PLI) they soon concluded that their voices were not being heard and decided instead to pursue their own land management proposal. ${ }^{89}$ The Bears Ears Inter-Tribal Coalition, ${ }^{90}$ that had come together to advocate for the landscape and in an attempt to collaborate on the PLI, developed and submitted to President Obama their own proposal to create a 1.9 million acre national monument. ${ }^{11}$ After more than two years of meetings with a wide range of stakeholders, and the failure of the PLI, President Obama designated the 1.35 million-acre Bears Ears National Monument - the first national monument ever designated at the request of Native Americans. ${ }^{92}$ As part of the designation, President Obama withdrew lands within the

85 Id. at 1139.

86 See Samuel J. Schmieding, Nat'L Park Serv., From Compromise to CoOperation: The Administrative History OF CANYONLANDS NATIONAL PARK 55-56 (2008).

87 See'Thomas Burr, Two More Monuments Planned in Utah?: Bishop Points to a Memo, but Interior Says It's a Draft, The SAlt Lake Tribune, Apr. 19, 2010, 2010 WLNR 3580745.

88 Krista Langlois, A 'Grand Bargain' for Utah Public Lands?, HiGH CounTRY NEws, Feb. 22, 2016, 2016 WLNR 8842310.

89 Keith Schneider, Waging a Monumental Battle Native Americans Prepare to Fight Trump on a Law that Preserves Sacred Land, Los ANGELES Times, Nov. 26, 2017, 2017 WLNR 36754556.

90 See, e.g., BeArs EARs Inter-TRIBAL COALITION, Tribes Uniting to Protect Bears Ears, https://perma.cc/XS33-5XTG. The Coalition is comprised of the Hopi Tribe, Navajo Nation, Ute Indian Tribe, Ute Mountain Ute Tribe, and Pueblo of Zuni. More than two dozen additional tribes and the National Congress of American Indians all formally support the Coalition.

91 Bears Ears inter-tribal Coalition, Proposal to President Barack Obama for the Creation of Bears EArs National Monument at 1 (Oct. 15, 2015) https://perma.cc/W55E-Y4R6.

92 Bears Ears Proc., supra note 3. 
** Pre-Publication Draft **

43 HARVARD ENVTL. L. REV. (2019)

monument area from availability for mineral leasing or development. ${ }^{93}$ Lands and resources within the Bears Ears National Monument are extraordinary by any measure. As the congressionally chartered National Trust for Historic Preservation describes:

[T] he public lands of San Juan County[, Utah] are among the most culturally significant in the country. Cedar Mesa ... . [has] archaeological site densities that rival and perhaps exceed those found within many nearby national parks and monuments. Also contributing to San Juan County's cultural significance is the resource diversity, ranging from evidence of Paleoindian occupation more than 11,000 years ago to the Hole-in-the-Rock Trail pioneered by Mormon settlers in the late 19th century. Finally, perhaps nowhere in the United States are so many well-preserved cultural resources found within such a striking and relatively undeveloped natural landscape. ${ }^{94}$

The National Trust for Historic Preservation also testified before Congress that "Bears Ears is one of the most significant cultural landscapes in the United States and a landscape that is home to more than 100,000 cultural and archaeological sites, many of which are sacred to tribal communities across the region." 95

The presidential proclamation designating the Monument goes to great lengths to describe this culturally, historically, and scientifically rich landscape. But what set Bears Ears apart was the way in which it afforded the Tribes a voice in monument management, carefully describing the monument's importance to Native American communities and establishing a Tribal Commission to "provide guidance and recommendations on the development and implementation of management plans." government of each of the five Tribes that had come together to create the proposal and who claimed the landscape as part of their ancestral home.

${ }^{93}$ Id. at 1143.

94 Letter from Barbara Pahl, Western Vice President, National Trust for Historic Preservation, to Congressmen Rob Bishop, Jason Chaffetz, \& Chris Stewart (July 10, 2013) (on file with author).

95 Utah Public Lands Initiative Act: Hearing on H.R. 5780 Before the H. Subcomm. on Federal Lands of the H. Comm. on Natural Resources, 114 ${ }^{\text {th }}$ Cong. 68 (Sept. 14, 2016) (testimony of Stephanie K. Meeks, President and CEO, National Trust for Historic Preservation).

96 Bears Ears Proc., supra note 3 at 1144. 
** Pre-Publication Draft **

43 HARVARD ENVTL. L. REV. (2019)

In repealing the 1.35 million-acre Bears Ears National Monument and replacing it with two smaller monuments totaling 201,876 acres, President Trump reduced the protected area by approximately eighty-five percent. ${ }^{97}$ Further, in identifying two prominent archaeological sites that continue to be protected as "noncontiguous parcels of land" to be included in the newly formed Shash Jaá National Monument, the proclamation highlighted the location of these remote and sensitive sites. ${ }^{98}$ Despite originally being designated largely because of the landscape's importance to Native Americans, the plaintiffs contend that "tens of thousands of historic and pre-historic structures, cliff dwellings, rock art panels (pictographs and petroglyphs), kivas, open service sites, pueblos, towers, middens, artifacts, ancient roads, historic trails, and other archaeological resources" will lose protection. ${ }^{99}$ This amounts to a loss of protection for approximately seventy-three percent of documented archaeological sites from the monument. ${ }^{100}$

The reduction also allegedly reduced protections for paleontological, recreation, geological, and ecological objects of cultural, scenic, and scientific interest, ${ }^{101}$ as exemplified by the recent discovery of "[o]ne of the world's richest troves of Triassic-period fossils" in an area that was part of the Bears Ears National Monument, but that is excluded from the smaller replacement monuments. ${ }^{102}$ This site, which "may be the densest area of Triassic period fossils in the nation, maybe the world," contains the remains of long-extinct fossilized crocodile-like creatures that roamed the earth more than 200 million years ago. ${ }^{103}$

Also, as with the Grand Staircase-Escalante National Monument, President Trump made the lands within Bears Ears that had been withdrawn from availability for mineral leasing and development by the original proclamation, available for such purposes sixty days after the date of the new proclamation. ${ }^{104}$

\section{Justifying Monumental Reductions}

President Trump set forth seven criteria for evaluating prior national

97 Bears Ears Modification Proc., supra note 3, at 58,085.

98 Id. at 58,083.

99 Complaint for Declaratory and Injunctive Relief at 55-56, Utah Diné Bikéyah v. Trump, 1:17cv-02605 (D. D. C. Dec. 6, 2017).

100 Id. at 58 .

101 Id. at 57-58.

102 Darryl Fears \& Juliet Eilperin, Spectacular Fossils Found at Bears Ears-Right Where Trump Removed Protections, The WAshington Post, Feb. 22, 2018, 2018 WLNR 5600085. 103 Id.

104 Bears Ears Modification Proc., supra note 3, at 58085. 
** Pre-Publication Draft **

43 HARVARD ENVTL. L. REV. (2019)

monument designations in his April 26, 2017 Executive Order:

(i) the requirements and original objectives of the Act, including the Act's requirement that reservations of land not exceed "the smallest area compatible with the proper care and management of the objects to be protected";

(ii) whether designated lands are appropriately classified under the Act as "historic landmarks, historic and prehistoric structures, [or] other objects of historic or scientific interest";

(iii) the effects of a designation on the available uses of designated Federal lands, including consideration of the multiple-use policy of section 102(a)(7) of the Federal Land Policy and Management Act (43 U.S.C. 1701(a)(7)), as well as the effects on the available uses of Federal lands beyond the monument boundaries;

(iv) the effects of a designation on the use and enjoyment of nonFederal lands within or beyond monument boundaries; (v) concerns of State, tribal, and local governments affected by a designation, including the economic development and fiscal condition of affected States, tribes, and localities;

(vi) the availability of Federal resources to properly manage designated areas; and

(vii) such other factors as the Secretary deems appropriate. ${ }^{105}$

Criteria (i) and (ii) reflect requirements contained in the Antiquities Act. ${ }^{106}$ Criteria (iii) through (vii) are completely unmoored from any identified statutory authority, reflecting instead the policy priorities of the new administration.

The President clearly has the right to direct the Secretary of the Interior to undertake a review based on any criteria that the President chooses. The President may also reasonably consider those criteria when deciding whether to designate a new national monument. But as Section II explains, the President's authority to revise existing national monuments is limited to authority granted to him by Congress when it passed the Antiquities Act. President Trump's Executive Order appears to create five new extra-statutory requirements for monument designation, and then impose those criteria on prior presidential decisions. In so doing, he may have impermissibly blurred the line between implementing the Antiquities Act and

105 Exec. Order 13,792, supra note 15, at 20,429-30.

106 See 54 U.S.C. \$S 320301(b) and (a), respectively. 
** Pre-Publication Draft **

43 HARVARD ENVTL. L. REV. (2019)

imputing new criteria into an existing law. It is also unclear whether President Trump can stand in judgement of factual determinations made by his predecessors under congressional delegated authority without impermissibly intruding on a judicial function.

Secretary Zinke's final report summarizing his findings appears to have been heavily influenced by the Trump administration's pro-development policies. As the Report explains:

When landscape areas are designated and reserved as part of a monument, objects and large tracts of land are overlain by a more restrictive management regime, which mandates protection of the objects identified. This has the effect of narrowing the range of uses and limiting BLM's multiple-use mission. As a result, absent specific assurances, traditional uses of the land such as grazing, timber production, mining, fishing, hunting, recreation, and other cultural uses are unnecessarily restricted. Such action especially harms rural communities in western states given that these towns have historically benefited and been economically sustained by grazing, mining, and timber production on nearby public lands. ${ }^{107}$

Secretary Zinke also opined that "[i]t appears that certain monuments may have been designated to prevent economic activity such as grazing, mining, and timber production rather than to protect specific objects." 108 With respect to the Grand Staircase-Escalante National Monument, the Secretary noted that "[a]reas encompassed within GSENM contain an estimated several billion tons of coal." 109 In shrinking the Grand Staircase-Escalante National Monument, President Trump appeared to recognize the tension between the criteria he set forth for the monument review and the authority contained in the Antiquities Act. President Trump's proclamation reducing the Grand Staircase-Escalante National Monument overtly focused on whether the boundary was the smallest necessary to protect the objects identified in the proclamation. As he explained:

107 Memo from Secretary Zinke, supra note 17, at 7. It is also noteworthy that in describing the BLM's "multiple-use mission," the Secretary dropped the "sustained yield" requirement contained in the same statutory clause. See, 43 U.S.C. \1701(a)(7).

108 Id.

109 Id. at 13 . 
** Pre-Publication Draft **

43 HARVARD ENVTL. L. REV. (2019)

[M] any of the objects identified by Proclamation 6920 are not unique to the monument, and some of the particular examples of those objects within the monument are not of significant historic or scientific interest. Moreover, many of the objects identified by Proclamation 6920 are not under threat of damage or destruction such that they require a reservation of land to protect them; in fact, many are already subject to Federal protection under existing law and agency management designations. ${ }^{110}$

He then concluded that "that the current boundaries of the Grand StaircaseEscalante National Monument established by Proclamation 6920 are greater than the smallest area compatible with the protection of the objects for which lands were reserved and, therefore, that the boundaries of the monument should be reduced."111 He also reduced the area withdrawn from mineral development to match those of the replacement monuments. ${ }^{112}$

Reducing the acreage subject to the mineral withdrawals is important because claims of lost opportunities to mine coal beneath the Grand Staircase-Escalante National Monument were among Utah's chief arguments for shrinking the monument-and Utah's congressional delegation fought hard for access to that coal. ${ }^{113}$ President Trump has also pledged to revive the coal industry, ${ }^{114}$ and has "focused on expanding oil, gas, and coal development and sweeping away Obamaera environmental initiatives that the administration contends hurt America's energy industry." 115 "[T] he effects of a designation on the available uses of designated Federal lands" was one of the criteria for review set forth by President Trump, ${ }^{116}$ and indeed, as part of its national monument review, the Office of the Secretary of the Interior "developed a series of estimates on the value of coal that could potentially be mined from a section of the Grand Staircase called the Kaiparowits plateau. As a result of Mr. Trump's action, major parts of the area are no longer a part of the

110 Grand Staircase-Escalante Modification Proc., supra note Error! Bookmark not defined., at 58,090 .

${ }^{111} I d$. at 58,091 .

$112 \mathrm{Id}$. at 58,093 .

113 Brian Maffly, What Does Kane County Want in a Redrawn Grand Staircase-Escalante Monument?, The SAlt LAKe Tribune (Nov. 21, 2017), at 6, available at https://perma.cc/3FQ5-AYTZ. ${ }^{114} \mathrm{Id}$.

115 Eric Lipton \& Lisa Friedman, Oil Was Central in Decision to Shrink Bears Ears Monument, Emails Show, THE New YorK Times (Mar. 2, 2018), at 1, available at https://perma.cc/8KNL-KNQV. 116 Exec. Order No. 13,792, supra note 17, at 20,429. 
** Pre-Publication Draft **

43 HARVARD ENVTL. L. REV. (2019)

national monument." "117 Reductions to the monument would, in the words of Utah's Senator Orrin Hatch, "allow coal mining in the Kaiparowits Plateau."

As with the Grand Staircase-Escalante National Monument, in his proclamation reducing Bears Ears President Trump concluded that "[s]ome of the objects Proclamation 9558 identifies are not unique to the monument, and some of the particular examples of these objects within the monument are not of significant scientific or historic interest." ${ }^{119}$ He therefore decided that:

Given the nature of the objects identified on the lands reserved by Proclamation 9558, the lack of a threat of damage or destruction to many of those objects, and the protection for those objects already provided by existing law and governing land-use plans, I find that the area of Federal land reserved in the Bears Ears National Monument established by Proclamation 9558 is not confined to the smallest area compatible with the proper care and management of those objects. ${ }^{120}$

Also like the Grand Staircase-Escalante, increasing access to minerals appeared to be a motivating factor behind monument reductions. As the Washington Post reported, "[a] uranium company launched a concerted lobbying campaign to scale back Bears Ears National Monument, saying such action would give it easier access to the area's uranium deposits and help it operate a nearby [uranium] processing mill." ${ }^{121}$ Senator Hatch, from Utah, also lobbied the Department of the Interior to remove land that contained oil and natural gas deposits from the monument. ${ }^{122}$ “The map that Mr. Hatch's office provided, which was transmitted about a month before Interior Secretary Ryan Zinke publicly initiated his review of national monuments, was incorporated almost exactly into the much larger reductions President Trump announced in December."123

117 Eric Lipton \& Lisa Friedman, supra note 115, at 3.

118 Thomas Burr \& Brian Maffly, Trump Headed to Utah in December With Plans to Shrink Bears Ears and Grand Staircase, THE SALT LAKE TRIBUNE (Oct. 28, 2017), at 3, www.sltrib.com/news/politics/2017/10/27/trump-tells-sen-orrin-hatch-hell-shrink-the-bearsears-national-monument/.

119 Bears Ears Modification Proc., supra note 3, at 58,081.

120 Id. at 58,082.

121 Juliet Eilperin, Uranium Firm Urged Trump Officials to Shrink Bears Ears National Monument, THE WASHington POST, Dec. 8, 2017, at 1, 2017 WLNR 38180442.

122 Eric Lipton \& Lisa Friedman, supra note 115.

123 Id. at 1 .

20181024 Draft 
** Pre-Publication Draft **

43 HARVARD ENVTL. L. REV. (2019)

And again, as with the Grand Staircase-Escalante, energy interests lobbied aggressively to reduce the monument and make development easier. As reported by the Washington Post, Energy Fuels Resources, which owns the only operating uranium mill in the United States,

hired a team of lobbyists at Faegre Baker Daniels-led by Andrew Wheeler, who is awaiting Senate confirmation as the Environmental Protection Agency's deputy secretary-to work on the matter and other federal policies affecting the company. ... The company's vice president of operations, William Paul Goranson, joined Wheeler and two other lobbyists, including former congresswoman Mary Bono (R-Calif.), to discuss Bears Ears in a July 17 meeting with two top Zinke advisers. ... "They heard what we had to say about the job losses, etc.," [Goranson] said. Zinke's deputies "were pretty positively disposed to" the idea of spurring future domestic uranium production. $^{124}$

The energy industry did not stop with lobbying the Department of the Interior. The New York Times obtained emails between Senator Hatch's staffers and the Department of the Interior showing that Energy Fuels Resources had emailed Senator Hatch maps indicating areas that it wanted removed from the monument. ${ }^{125}$ Senator Hatch then suggested boundary revisions to the Trump administration, and the boundaries of the reduced Bears Ears National almost perfectly matches the one proposed by Hatch for that corner of the monument. ${ }^{126}$

As Section III shows, the Trump administration's reasons for reductions to both Bears Ears and the Grand Staircase-Escalante national monuments have little if any historic precedent.

124 Juliet Eilperin, Uranium Firm Sought Bears Ears Cut, THE WASHINGTON POST, Dec. 10, 2017, 2017 WLNR 38279283

125 Brian Maffly, Uranium Mill Pressed Trump Officials for Bears Ears Reductions, Records Show, SALT LAKE TRIBUNE, Dec. 13, 2017, www.sltrib.com/news/2017/12/13/uranium-mill-pressedtrump-officials-for-bears-ears-reductions-records-show/.

126 Brian Maffly, Oil and Coal Drove Trump's Call to Shrink. Bears Ears and Grand Staircase, According to Insider Emails Released by Court Order, SALT LAKE TRIBUne, March 2, 2018, www.sltrib.com/news/environment/2018/03/02/interior-department-emails-show-oil-andcoal-played-a-big-role-in-bears-ears-grand-staircase-monument-redraws/. 
** Pre-Publication Draft **

43 HARVARD ENVTL. L. REV. (2019)

\section{The President's Power to Reduce or Repeal a National Monument}

Whether President Trump exceeded his authority in reducing the Bears Ears and the Grand Staircase-Escalante national monuments will likely turn on how courts interpret the Antiquities Act. ${ }^{127}$ Professor Squillace and others have carefully reviewed the Act's legislative history and argue persuasively that Congress did not intend for Presidents to radically revise national monuments. ${ }^{128}$ This section builds on that work, combining a textual review of the Act with a discussion of historical context to ascertain congressional intent, and concluding that Congress did not intend for Presidents to revise national monuments in radical and unilateral ways. Section III builds on this analysis, asking whether, regardless of the original intent of Congress, that body acquiesced in a broader assertion of power by the President.

The President's authority, "as with the exercise of any governmental power, 'must stem either from an act of Congress or from the Constitution itself.", 129 Beginning with the Constitution, the Property Clause states that " $[\mathrm{t}]$ he Congress shall have Power to dispose of and make all needful Rules and Regulations respecting the Territory and other Property belonging to the United States." 130 According to the Supreme Court, the Property Clause "implies an exclusion of all other authority over the property which could interfere with this right or obstruct its exercise."131 The Constitution contains no grant of power over our public lands to the President, who must therefore obtain congressional authorization before acting in this arena.

In passing the Antiquities Act, Congress made such a grant, delegating to the President the discretionary authority to:

127 A President's power to expand a national monument does not appear to be in question, as the President does so by issuing a new proclamation consistent with his delegated authority under the Antiquities Act. The new proclamation identifies the resources to be protected and the area that he deems necessary to protect those resources, again consistent with the requirements set forth in the Antiquities Act. The Department of Justice concedes that "[n]o authority has been asserted by the President to support the Proclamation [reducing Bears Ears National Monument] in the event the Antiquities Act is held not to authorize it." Memorandum in Support of Federal Defendants' Motion to Dismiss 41, Hopi Tribe v. Trump, 1:17-cv-02590 (Consolidated Cases, D.D.C. Dec. 6, 2017).

128 See Squillace, supra note 21, at 583; see also Squillace et al., supra note 6, at 56.

129 Medellin v. Texas, 552 U.S. 491, 524 (2008) (quoting Youngstown Sheet \& Tube Co. v. Sawyer, 343 U.S. 579, 585 (1952); see also Dames \& Moore v. Regan, 453 U.S. 654, 668 (1981)). 130 U.S. CONST. art. IV, $₫ 3$, cl. 2.

131 Wis. Cent. R. Co. v. Price Cty., 133 U.S. 496, 505 (1890), (citing Van Brocklin v. Anderson, 117 U.S. 151, 168 (1886)). 
** Pre-Publication Draft **

43 HARVARD ENVTL. L. REV. (2019)

[D]eclare by public proclamation historic landmarks, historic and prehistoric structures, and other objects of historic or scientific interest that are situated on land owned or controlled by the Federal Government to be national monuments.... The limits of the parcels shall be confined to the smallest area compatible with the proper care and management of the objects to be protected. ${ }^{132}$

Neither the Antiquities Act itself not the legislative hearings leading up to its passage mention monument reductions or revocation. The question therefore becomes how to interpret that silence. While passage of the Antiquities Act recognized a compelling need for quick action to protect sensitive resources, there was no comparable need to swiftly reduce protected areas, and therefore no reason for Congress to divest itself of those powers. In other statutes authorizing the President to make public land designations Congress expressly authorized the President to revise those designations. The choice to not include such language in the Antiquities Act therefore appears intentional. Congress, moreover, repeatedly rejected legislation that would have empowered the President to revise national monument boundaries, indicating both that it knew the President lacked such powers and that it intended to retain revisionary power for itself. Executive branch documents demonstrate that, until recently, Presidents understood and accepted these limitations on the scope of their delegated power.

\section{A. The Antiquities Act: To Promote Swift and Expansive Action}

Congress passed the Antiquities Act because treasured landscapes and the irreplaceable objects that they contain often were under threat from unconstrained exploitation. ${ }^{133}$ Swift action was required in the face of pressing threats, and Congress deemed itself poorly suited to the fact-finding required to identify the myriad sites at risk, or to formulate the site-specific protections each site required. Congress, therefore, granted that power and responsibility to the President. ${ }^{134}$

Any delegation of power by Congress to the Executive Branch must have "clear expression or implication." "35 Such a delegation to the Executive Branch should therefore be "directly conferred and not left to be guesses from a

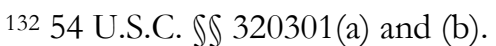

133 Squillace, supra note 21, at 477-486.

134 Annual Report of the Commissioner of the General Land Office to the Secretary of the Interior, at 59-60 (1904).

135 Cochnower v. United States, 248 U.S. 405, 407, aff'd, 249 U.S. 588 (1919).
} 
** Pre-Publication Draft **

43 HARVARD ENVTL. L. REV. (2019)

circumlocution of words or to be picked out of a questionable ambiguity." ${ }^{136}$ While swift action may be required to protect sensitive resources from imminent harm, there is no comparable need for swift action to reduce or rescind a national monument. Congress had no reason to divest itself of its constitutional authority over the fate of such decisions, and divestiture should be found based on congressional silence. The separation of powers set forth in our Constitution is too important to disassemble by implication. To now endow a President with near limitless power to unilaterally alter national monuments also infuses unnecessary uncertainty into public land management. This is surely not what Congress intended.

Reducing landscape-scale monuments that contain tens or even hundreds of thousands of artifacts and irreplaceable resources to multiple mini-monuments, as was done at Bears Ears, may also call undo attention to the sensitive archaeological sites than many monuments are designed to protect, inviting looting and defeating the very purpose for designating the monument. Indeed, President Trump's proclamation identifies two isolated and sensitive cliff dwellings by name and maps their location, attracting visitors to sensitive sites that were previously protected by their remote location and relative anonymity. Congress implicitly recognized that the threats facing resource-rich landscapes can be compelling, and that entire landscapes may require protection as national monuments. Indeed, on twenty-five occasions Congress ratified landscape-scale monuments by incorporating them into national parks, national preserves, or other more protective designations. ${ }^{137}$

This does not imply that those seeking to modify either a national monument boundary or management of the lands within monument boundaries are without redress. Congress has the power to revise or even eliminate a national monument. In 1955, for example, Congress eliminated the Old Kasaan National Monument in Alaska after the totem poles that the monument was designated to protect had been moved to a museum. ${ }^{138}$ Congress, in 1956, eliminated the Castle Pinkney National Monument, which had fallen into disrepair and was no longer devoted to historic preservation. ${ }^{139}$ In 1930, Congress transferred Papago Saguaro National Monument to the state of Arizona, ${ }^{140}$ and three years later, it was replaced with the much larger

\footnotetext{
136 Id. at 408.

137 Nat'l Parks Conservation Ass'n, supra note 23.

138 An Act to Abolish the Old Kasaan National Monument and for Other Purposes, 69 Stat. 380, Pub. L. No. 179 (1955).

139 An Act to Abolish the Castle Pinckney National Monument, in the State of South Carolina, 70 Stat. 61, Pub. L. No. 447 (1956).

140 An Act to Abolish the Papago Saguaro National Monument, Arizona, 46 Stat. 142, Pub. L.
} 
** Pre-Publication Draft **

43 HARVARD ENVTL. L. REV. (2019)

Saguaro National Monument. ${ }^{141}$ But decisions about the fate of national monuments appear best left, and intentionally left, to the more deliberative halls of Congress.

\section{B. Laws Authorizing Presidents to Revise Other Land Designations}

Congress has demonstrated that it knows how to enact laws that allow the President to protect land, and afford the President the ability to later revisit those designations if circumstances changed. Congress included such two-way authorities in other statutes, and had they intended to grant the President the power to revise or revoke national monuments, Congress could have adopted that approach in the Antiquities Act. But, Congress did not do so. The Court "presume[s] that where words differ [between statutes] . . Congress acts intentionally and purposefully in the disparate inclusion or exclusion." "142 The different choice of language used in the Antiquities Act should be respected.

The practice of Congress authorizing the President to set aside public lands and to subsequently revise those reservations predates the Antiquities Act. In 1884, for example, Congress empowered the President to determine whether lands within military reservations "[had] become useless for military purposes" and turn such "useless" land over to the Secretary of the Interior for "disposition." "143 In the Appropriations Act of 1889, Congress recognized the President's power to reserve lands from settlement and said that "the President may at any time in his discretion by proclamation open any portion or all of the lands reserved by this provision to settlement under the homestead laws."144 stated that:

In the Department of Agriculture Appropriations Act of 1898, Congress

The President is hereby authorized at any time to modify any

Executive order that has been or may hereafter be made establishing

$$
\text { No. 71-92 (1930). }
$$

141 Proclamation No. 2032, 47 Stat. 2557 (1933).

142 Burlington Northern \& Santa Fe Ry. Co. v. White, 548 U.S. 53, 63 (2006) quoting Russello v. United States, 464 U.S. 16, 23 (1983).

143 An Act to Provide for the Disposal of Abandoned and Useless Military Reservations, 23 Stat. 103, 103 (1884).

${ }^{144}$ An Act Making Appropriations for Sundry Civil Expenses of the Government for the Fiscal Year Ending June Thirtieth, Eighteen Hundred and Eighty-Nine, 25 Stat. 505, 527 (1888), repealed by Federal Land Policy and Management Act, 43 U.S.C. SS 1701-84 (1976) [hereinafter FLPMA]. 
** Pre-Publication Draft **

43 HARVARD ENVTL. L. REV. (2019)

any forest reserve, and by such modification may reduce the area or change the boundary lines of such reserve, or may vacate altogether any order creating such reserve. ${ }^{145}$

Later that same year, Congress, in an act extending the homestead laws to the District of Alaska, stated that "the President is authorized and empowered, in his discretion, by Executive order from time to time to establish or discontinue land districts in the District of Alaska, and to define, modify, or change the boundaries thereof, and designate or change the location of any land office therein."146

In 1910, just four years after passage of the Antiquities Act, Congress passed the Pickett Act, allowing the President to "temporarily withdraw [land] from settlement, location, sale, or entry" for "water-power sites" or for other purposes "until revoked by him or by an Act of Congress."147

Section 300 of the Stock-Raising Homestead Act of 1916 allowed the President to withdraw from availability for disposal pursuant to laws like the Homestead Act of 1862, "[1] ands containing water holes or other bodies of water needed or used by the public for watering purposes" pursuant to the process set forth in the Pickett Act. ${ }^{149}$ By incorporating the Pickett Act's withdrawal and revocation provisions into the Stock-Raising Homestead Act, Congress allowed the President to reserve and revoke water reservations under that Act. Congress incorporated the same language into section 299 of the Homestead Act, which required notations on all coal and mineral patents indicating that they too were subject to the Pickett Act's withdrawal and withdrawal revocation procedures. ${ }^{150}$

In 1928, Congress passed the Colorado River Compact Act, authorizing the Secretary of the Interior to withdraw all lands that were suitable for irrigation and reclamation until he determined that such lands should be made available for disposal under provisions of reclamation law. ${ }^{151}$ Similarly, Congress passed the Rio

145 An Act Making Appropriation for the Department of Agriculture for the Fiscal Year Ending June Thirtieth, Eighteen Hundred and Ninety-Eight, 30 Stat. 11, 36 (1897).

146 An Act Extending the Homestead Laws and Providing for Right of Way for Railroads in the District of Alaska, 30 Stat. 409, 414 (1898).

14743 U.S.C. $₫ 141$ (1970) (repealed by FLPMA).

14843 U.S.C. \$\$ 161-284 (1970) (repealed by FLPMA).

14943 U.S.C. \ 300 (1970) (repealed by FLPMA).

15043 U.S.C. \$ 299 (1970) (repealed by FLPMA).

151 An Act to Provide for the Construction of Works for the Protection and Development of the Colorado River Basin, for the Approval of Colorado River Compact, 45 Stat. 1057, 1063 (1928). 
** Pre-Publication Draft **

43 HARVARD ENVTL. L. REV. (2019)

Grande Compact Amendment Act in 1935, authorizing the President to "withdraw from sale, public entry or disposal" any such lands he deemed necessary to fulfill the compact, "[p]rovided, That any such withdrawal may subsequently be revoked by the President." 152

Congress was even more direct in 1940 when it empowered the President "to reserve and set aside from all forms of location, entry, or appropriation any nationalforest lands ... and such reservations shall remain in force until revoked by the President or by an Act of Congress." 153 Congress, on at least two occasions, also granted executive branch officials the right to grant and later revoke easements and rights-of-way across public lands and reservations. ${ }^{154}$

Had Congress intended to endow the President with the power not only to create national monuments, but to later reduce or repeal them, Congress could have adopted these established models or amended the Antiquities Act to include such provisions. But Congress included no such language in the Antiquities Act, and their choice of words should be given effect.

\section{Bills Authorizing Presidents to Modify National Monument Proclamations}

Congressional efforts to grant the President or other executive branch officers the power to revise national monuments are also telling. In the rare instances that Congress did empower the President or his subordinates to revise a monument, Congress did so only on a narrow monument-specific basis and in light of a clearly articulated public benefit. Congress has never authorized the President to make wholesale or discretionary national monument reductions or modifications.

On at least four occasions Congress authorized the executive branch to revise monument boundaries as part of land exchanges that removed non-federal inholdings from monuments or that allowed monument managers to acquire lands needed for monument management. As discussed further in section III, Congress in

\footnotetext{
152 An Act to Amend the Act of May 13, 1924, entitled "An Act Providing for a Study Regarding the Equitable use of the Waters of the Rio Grande," and so forth, as Amended by the Public Resolution of March 3, 1927, 49 Stat. 661 (1935).

153 An Act to Authorize the Withdrawal of National-Forest Lands for the Protection of Watersheds from Which Water is Obtained for Municipalities, 54 Stat. 224 (1940).

${ }^{154}$ An Act Relating to Rights of Way Through Certain Parks, Reservations, and Other Public Lands, 31 Stat. 790 (1901); and An Act Making Appropriations for the Department of Agriculture for the Fiscal Year Ending June Thirtieth, Nineteen Hundred and Twelve, Pub. L. No. 478, 36 Stat. 1235, 1253 (1911).
} 
** Pre-Publication Draft **

43 HARVARD ENVTL. L. REV. (2019)

1958 authorized the Secretary of the Interior to trade lands within the Black Canyon of the Gunnison National Monument for private lands that were needed "in order to facilitate administration of such monument." 155 The acquired lands allowed the Park Service to improve the main road through the monument which provided access to the canyon that inspired the monument's designation, and to develop a much needed monument headquarters area as well as picnic and campground facilities. ${ }^{156}$

Congress approved similar exchanges and boundary revisions involving Scotts Bluff National Monument in Nebraska, ${ }^{157}$ and at Montezuma Castle National Monument in Arizona. ${ }^{158}$ At Scotts Bluff, the existing boundary did not follow natural and developed features like "draws, ridges, rivers and irrigation ditches.... A more practicable boundary . . . could facilitate protection, obviate the need for considerable fencing, and provide a more esthetic transition from the natural conditions of the monument to the cultivated or developed areas beyond its boundaries." 159 The lands added to the monument foreclosed development of a dump, borrow pit, and utilities along the monument's boundary while also including Dome Rock, a prominent geologic feature that was bisected by the existing boundary. ${ }^{160}$ Excluded lands included "privately owned land . . . that ha[d] no known scenic, scientific, or historic values. Some of it is highly productive irrigated land which does not appear prominently in the vies of a visitor to the monument."161

Years earlier, in 1930, Congress also authorized the President to designate the Colonial National Monument in Virginia, ${ }^{162}$ and to later expand and adjust that monument's boundaries as needed when state, private, and other federal lands were made part of the monument. ${ }^{163}$ Notably, in proclaiming Colonial National

155 An Act to Authorize the Exchange of Certain Lands at Black Canyon of the Gunnison National Monument, Colorado, Pub. L. No. 85-391, 72. Stat. 102 (1958).

156 See Colorado National Monument, Dept. of the Interior, Superintendent's Annual Report Black Canyon of the Gunnison National Monument 1956 Fiscal Year 3 (May 18, 1956) (on file with author).

157 See An Act to Revise the Boundaries of the Scotts Bluff National Monument, Nebraska, Pub. L. No. 87-68, 75 Stat. 148 (1961).

158 See National Parks and Recreation Act of 1978, Pub. L. No. 95-625, 92 Stat 3467, 3474 (1978).

159 Revising the Boundaries of Scotts Bluff National Monument, Nebr., S. Rep. No. 432, at 3 (1961).

${ }_{160} I d$.

${ }^{161} \mathrm{Id}$.

162 See An Act to Provide for the Creation of the Colonial National Monument in the State of Virginia, Pub. L. 71-510, 46 Stat. 855 (1930).

163 See An Act to Amend an Act Entitled "An Act to Provide for the Creation of the Colonial 
** Pre-Publication Draft **

43 HARVARD ENVTL. L. REV. (2019)

Monument, President Hoover relied not on the Antiquities Act, but on "An Act to Provide for the Creation of the Colonial National Monument in the State of Virginia, and for Other Purposes." "164 When he modified the boundary in 1933 to accommodate a re-routed Parkway between Williamsburg and Jamestown Island, he did so based on authority expressly delegated to him by Congress rather than Antiquities Act Authority. ${ }^{165}$ Any adjustment to the Colonial National Monument therefore did not implicate the Antiquities Act. In 1998, Congress ratified a previously negotiated exchange between the Department of the Interior and the state of Utah that involved lands within the Grand Staircase-Escalante National Monument. ${ }^{166}$

Seven times members of Congress introduced legislation that would have granted the President the power to remove land from a national monument. Six times those efforts failed (one bill remains pending). ${ }^{167}$ Courts are of course generally reluctant "to attribute significance to the failure of Congress to act on particular legislation" 168 because "several equally tenable references may be drawn from such inaction."169 "[P] rolonged and acute awareness" of an issue, however, can support a conclusion that Congress rejected propositions contained in the legislation. ${ }^{170}$ Here, repeated but unsuccessful efforts to grant the President the power to reduce or repeal national monuments indicate both that Congress understood that the President lacked these powers, and that Congress intended to retain such power for itself.

By the early 1920s, the Department of the Interior was working hard to bring irrigation water to the Gila River Indian Reservation in Arizona. Congress had already appropriated funds and substantial work had been completed on that project, ${ }^{171}$ but to complete the system the Department of the Interior needed to

National Monument in the State of Virginia, and for Other Purposes, Approved July 3, 1930," Pub. L. No. 71-792, 46 Stat. 1490 (1931).

164 See Proclamation No. 1929 (Dec. 30, 1930) [hereinafter Colonial Proc.], citing Pub. L. No. 71 510 (1930).

165 See Proclamation No. 2055. (Aug. 22, 1933) [hereinafter Colonial Modification Proc.].

166 An Act to Provide for the Exchange of Certain Lands within the State of Utah, 112 Stat. 3139, Pub. L. No. 105-335 (1998).

167 See H.R. 3990, 115th Cong. \ 2 (2017).

168 Red Lion Broad. Co. v. FCC, 395 U.S. 367, 381 n. 11 (1969).

${ }_{169}$ Cent. Bank of Denver v. First Interstate Bank of Denver, 511 U.S. 164, 187 (1994).

170 Bob Jones Univ. v. United States, 461 U.S. 574, 601 (1983).

171 S. REP. NO. 423 (1926). 
** Pre-Publication Draft **

43 HARVARD ENVTL. L. REV. (2019)

construct a canal through Casa Grande National Monument. ${ }^{172}$ In 1924 the Assistant Secretary of the Department of the Interior issued an opinion concluding that only Congress could authorize an irrigation lateral through the monument. As he explained,

I am of the impression that this canal would not injure the reservation and that it is probably desirable and perhaps even essential from an engineering standpoint that it be constructed along the line laid down. Authority to do this can doubtlessly be obtained at the next session of Congress. In my opinion, the Department has no power to authorize the construction under present law. ${ }^{173}$

Congress took up the issue the next year, when Senator Harreld of Oklahoma introduced a bill to remove from the monument the land through which the canal would pass. Senator Harreld's bill stated that "hereafter the President of the United States is authorized in his discretion to eliminate lands from national monuments by proclamation." "174 The bill died in committee. Senator Harreld reintroduced his bill the next year and it was enacted into law-but only after the Senate struck the provision regarding presidential authority to eliminate lands from national monuments. ${ }^{175}$ That was the only amendment to Senator Harreld's bill.

In 1925, Senator Ladd of North Dakota and Representative Sinnott of Oregon introduced separate bills authorizing the President to restore to the public domain any national monument lands that were no longer needed for monument purposes. ${ }^{176}$ Both bills pertained only to presidential monument reductions, and both bills died in committee.

In 1930, Senator Nye of North Dakota unsuccessfully tried to grant the President the power to "enlarge or diminish" the Colonial National Monument "by subsequent proclamation." 177 Finally, in 1933, Representative Arentz of Nevada introduced a bill to authorize the President to adjust the boundaries of Death Valley

\footnotetext{
172 See Opinion of F.M. Goodwin, Asst. Sec'y of the Dep't of the Interior, Extension of Irrigation Canals Over Lands Within a National Monument, 50 Pub. Lands Dec. 569 (June 27, 1924).

173 Id. at 571. Note, however, that the Solicitor based his opinion on the Act of March 3, 1921, 41

Stat. 1353, rather than on the Antiquities Act.

174 S. 3826, 68th Cong. 2d. Sess. (1925).

175 See S. 2703, 69th Cong. 1st Sess. (1926).

176 See S. 3840, 68th Cong. (1925); and H.R. 11357, 68th Cong. (1925).

177 See S. 4617, 71st Cong. 2d Sess. (1930).
} 
** Pre-Publication Draft **

43 HARVARD ENVTL. L. REV. (2019)

National Monument via presidential proclamation. ${ }^{178}$ This bill never made it out of the House of Representatives.

On October 6, 2017, Congressman Rob Bishop introduced the "National Monument Creation and Protection Act" that would, among other features, authorize a President to unilaterally reduce a monument by up to 85,000 acres and to make larger reductions to a monument with the approval of the state where the monument resides. ${ }^{179}$ As of the writing of this article, Congressman Bishop's bill has not been brought to the floor for a vote.

While far from definitive evidence that Congress never intended to endow the President with the power to reduce national monuments, the rejection of every effort to grant him such powers is part of the larger tapestry of evidence of congressional intent. Taken together, the weight of the evidence indicates that President Trump may have overreached his authority when he reduced Bears Ears and the Grand Staircase-Escalante national monuments.

\section{Executive Branch Understanding of Congressional Intent}

Even the executive branch has historically taken a dim view of the President's power to repeal a national monument and to return reserved lands to the public domain. Franklin Roosevelt attempted to repeal Castle Pinkney National Monument and grant the land to South Carolina because the fort for which the monument was proclaimed had fallen into disrepair and "the public has not manifested any great interest in it as an object of historical importance." ${ }^{\prime 80} \mathrm{He}$ abandoned the effort in favor of congressional action after Attorney General Cummings opined that the President was "without the authority to issue the proposed proclamation." 181 After reviewing President Roosevelt's proposed proclamation, the Attorney General concluded that while the President may have the power to revise a national monument to ensure that it was " "confined to the smallest area compatible with the proper care and management of the objects to be protected,' it does not follow from his power so to confine that area that he has the power to abolish a national monument entirely." "182

The Attorney General's comments about the President's authority to reduce a monument were both cursory in nature and irrelevant to the issue he was asked to

178 See H.R. 14,646, 72d Cong. 2d Sess. (1933).

179 H.R. 3990, 115th Cong. \$2(j) (2017).

18039 Op. Att'y Gen. 185, 186 (1938).

${ }^{181} I$ d. at 189.

182 Id. at 188 (quoting the Antiquities Act as currently codified at 54 U.S.C. $\$ 320301$ ). 
** Pre-Publication Draft **

43 HARVARD ENVTL. L. REV. (2019)

determine, namely the President's authority to eliminate a monument. They also appear to have little relevance to Bears Ears and the Grand Staircase-Escalante, where thousands of resources identified in the original monument proclamations were left with significantly less protection. President Trump's reductions are not a case of confining a monument to the smallest area necessary to protect sensitive resources. They are a case of eliminating protections for thousands of irreplaceable objects of historic and scientific import.

Attorney General Cumming's discussion of revocation was more detailed and useful in interpreting the Antiquities Act. As he explained, when the President created a national monument, he was acting under authority delegated to him by Congress. As such, the monument

was in effect a reservation by the Congress itself, and the President therefore was without the power to revoke or rescind the reservation. ... 'A duty properly performed by the Executive under statutory authority has the validity and sanctity which belong to the statute itself, and, unless it be within the terms of the power conferred by that statute, the Executive can no more destroy his own authorized work, without some other legislative sanction, than any other person can. To assert such a principle is to claim for the Executive the power to repeal or alter an act of Congress at will. ${ }^{183}$

While the 1938 Attorney General opinion is the only opinion to directly address the President's authority to reduce or repeal national monuments, it builds on opinions addressing other categories of federal lands and holding that the President may not dispose of or return to the public domain lands that had previously been exempted from disposal. ${ }^{184}$ For instance, in 1881 Attorney General MacVeagh concluded that where the President relies on statutory authority to reserve public lands for a public purpose, "he is to be regarded as acting by authority of Congress ... which alone can authorize such disposition of the public domain. It cannot, therefore, be diverted from that use . . except by the same authority." ${ }^{\prime 185}$

18339 Op. Att'y Gen. at 187 (quoting 10 Op. Att'y Gen. 359, 364 (1862)).

18432 Op. Att'y Gen. 488, 490 (1921); 28 Op. Att'y Gen. 143, 144 (1910); 21 Op. Att'y Gen. 120 (1895); 10 Op. Att'y Gen. 359 (1862).

18517 Op. Att'y Gen. 168, 168 (1881). See also 16 Op. Att'y Gen. 121, 123 (1878) ("if lands have been once set apart by the President in an order for military purposes, they cannot again be restored to the condition of public lands ... except by an authority of Congress.’). 
** Pre-Publication Draft **

43 HARVARD ENVTL. L. REV. (2019)

Implied in Mr. MacVeagh's opinion is the understanding that the expressed power to designate does not include an implied but unexpressed power to undo.

This comports with Attorney General Bates' 1862 opinion holding that the President derives his authority to appropriate land to a public or governmental purpose "not from any power over the public lands inherent in his office, but from an express grant of power from Congress ... he had no power to take them out of the class of reserved lands, and restore them to the general body of public lands.... If the President could not [remove lands from the public domain] without the aid of Congress, neither could he annul the same work without the same aid."186

The Department of the Interior has also addressed the President's authority to repeal or replace national monuments, though their conclusions have been inconsistent. Opinions from $1915^{187}, 1935^{188}$, and $1947^{189}$ contend that the President could revise monument boundaries. But two opinions from $1924^{190}$, and opinions from $1932^{191}$ contend that he could not, as does a1943 opinion involving Olympic National Park. ${ }^{192}$ The 1935 opinion is notable because the Solicitor was asked to opine on the legality of three prior to Mt. Olympus National Monument dating to 1912 and totaling over 300,000 acres. The Solicitor, who was an Executive Department official, had little incentive to restrain Executive power, especially when it meant calling into question twenty-three years of management, including the legality of timber sales that had occurred over the intervening years. Incentives aside, "[a]n agency interpretation of a relevant provision which conflicts with the agency's earlier interpretation is 'entitled to considerably less deference' than a consistently held agency view." "193 Having reversed itself on four separate occasions, and having

\footnotetext{
18610 Op. Att'y Gen. at 363-64.

${ }^{187}$ Letter from Preston West, Solicitor, Dept. of the Interior, to the Sec'y of the Interior (April 20, 1915) (on file with author).

188 Dept. of the Interior M. Opp. 27657 (Jan. 30, 1935). One cannot help but wonder whether this opinion was influenced, at least in part, by practical concerns over upending twenty-three years of settled expectations, as it was the only opinion to reflect back on the legality of prior reductions.

189 Dept. of the Interior M. Opp. 34978, 60 I.D. 9, 10 (July 21, 1947). [

190 Dept. of the Interior M. Opp. 12501 (June 3, 1924); 50 I.D. 569 (June 27, 1924).

191 Dept. of the Interior M. Opp. 27025 (May 16, 1932).

19258 I.D. 480 (June 20, 1943).

193 Good Samaritan Hosp. v. Shalala, 508 U.S. 402, 417 (1993) (internal citations omitted); see also Pauley v. BethEnergy Mines, Inc., 501 U.S. 680, 698 (1991) ("the case for judicial deference is less compelling with respect to agency positions that are inconsistent with previously held views.”).
} 
** Pre-Publication Draft **

43 HARVARD ENVTL. L. REV. (2019)

little incentive to disclaim power, Executive Branch opinions merit little deference. Finally, the George W. Bush administration in 2002argued before the U.S. Supreme Court that "Congress's intent could not be more clear. Congress broadly authorized the President to establish national monuments." 194 The establishment of Glacier Bay National Monument was "intended to be permanent . . . only Congress could abolish a national monument. Congress was well aware of the need for legislation to abolish national monuments." $" 195$ Two committees of the U.S. House of Representatives had stated as much in clear and unequivocal terms-a monument declaration "will be permanent unless it is modified by Congress." 196

Permanence is important. Congress could hardly have intended for national monuments to become political footballs, protected by one administration only to be eliminated by the next, and subject to potential re-establishment and rediminishment by subsequent administrations. Presidents, until Donald Trump, also appear to have had similar expectations. On at least twenty-two occasions, Presidents have temporarily withdrawn federal lands from availability for disposal or mineral development while they reviewed the land's suitability for inclusion in a national monument. ${ }^{197}$ Had Presidents intended monuments to be temporary in nature they

\footnotetext{
${ }^{194}$ Memorandum in Support of Motion of the U.S. for Partial Summary Judgment on Count IV of the Amended Complaint at 44, Alaska v. United States, 546 U.S. 413 (2006) (No. 128, Original).

${ }^{195} \mathrm{Id}$.

196 H.R. Rep. No. 96-97, pt. 2 at 93 (1979); see also H.R. Rep. No. 96-96, pt. 1 at 393 (1979); Office of Technology Assessment: Options for Access in Alaska 4 (1979).

${ }_{197}$ Exec. Order No. 3297 (Woodrow Wilson, June 6, 1920); Exec. Order No. 3314 (Woodrow Wilson, July 26, 1920); Exec. Order No. 3345 (Woodrow Wilson, Oct. 23, 1920); Exec. Order No. 3450 (Warren Harding, May 3, 1921); Exec. Order No. 3650 (Warren Harding, Mar. 20, 1922); Exec. Order No. 3743 (Warren Harding, Sept. 30, 1922); Exec. Order No. 3755 (Warren Harding, Nov. 17, 1922); Exec. Order No. 3976 (Calvin Coolidge, Mar. 22, 1924); Exec. Order No. 3983 (Calvin Coolidge, April 1, 1924); Exec. Order No. 4103 (Calvin Coolidge, Nov. 20, 1924); Exec. Order No. 5038 (Calvin Coolidge, Feb. 2, 1929); Exec. Order No. 5105 (Herbert Hoover, May, 3, 1929); Exec. Order No. 5201 (Herbert Hoover, Oct. 3, 1929); Exec. Order No. 5276 (Herbert Hoover, Feb. 7, 1930); Exec. Order No. 5339 (Herbert Hoover, Apr. 25, 1930); Exec. Order No. 5408 (Herbert Hoover, July 25, 1930); Exec. Order No. 5573 (Herbert Hoover, Mar. 7, 1931); Exec. Order No. 6212 (Franklin Roosevelt, July 25, 1933); Exec. Order No. 6285 (Franklin Roosevelt, Sept. 14, 1933); Exec. Order No. 6361 (Franklin Roosevelt, Oct. 25, 1933); Exec. Order No. 6477 (Franklin Roosevelt, Dec. 6, ); Exec. Order No. 7888 (Franklin Roosevelt, May 16, 1938). On April 24, 1943, President Roosevelt delegated to the Secretary of the Interior the authority to make all public land withdrawals that were otherwise within the President's power. Exec. Order No. 9337 (Franklin
} 
** Pre-Publication Draft **

43 HARVARD ENVTL. L. REV. (2019)

would not have gone through this unnecessary and redundant two-step process.

When taken together with other evidence, the weight of opinion by prior administrations appears to support an understanding that Congress did not intend to endow the President with the power to radically reduce national monuments. One important exception exists, and that is where we turn next.

\section{E. The Power Implied by Congressional Acquiescence}

The strongest argument in favor of the President's power to revise a national monument may arise from the two-dozen or so prior presidential national monument reductions and the failure of Congress to object to those presidential actions. These prior reductions were never challenged in court, however, and no court has yet ruled on their legality. Although there may be circumstances in which congressional acquiescence in monument reductions can create a presumption in favor of such presidential powers, any such power should be limited by subsequent legislative action and the narrowly interpreted facts surrounding prior reductions. ${ }^{198}$

More than a century ago, the Supreme Court in United States v. Midwest Oil Co., held that a congressional delegation of power to the President can be found by virtue of congressional acquiescence in prior executive actions. ${ }^{199}$ Midwest Oil considered whether the President had authority to set aside lands as a naval petroleum reserve. While Congress had not expressly authorized the President to withdraw the lands at issue from operation of laws authorizing the sale or disposal of the public lands, ${ }^{200}$ the Supreme Court concluded that congressional acquiescence in 109 executive orders establishing or enlarging military reservations, 99 executive orders establishing or enlarging Indian reservations, and 44 executive orders establishing bird refuges indicated acquiescence in an implied power to reserve public lands from development.

As the Court explained, Congress had "uniformly and repeatedly acquiesced in the [presidential] practice" of withdrawing lands by executive order for myriad

Roosevelt, Apr. 24, 1943).

198 Any delegation of authority by Congress to the executive branch must have "clear expression or implication." Cochnower v. United States, 248 U.S. 405, 407, judgment modified, 249 U.S. 588 (1919).

${ }^{199}$ United States v. Midwest Oil Co., 236 U.S. 459 (1915).

200 Public lands were commonly disposed of via grants to states, railroads, homesteaders, miners, returned military veterans, and others. For a background on public land disposal laws, see PAUL W. GATES, supra note 56. 
** Pre-Publication Draft **

43 HARVARD ENVTL. L. REV. (2019)

purposes without explicit statutory authorization. ${ }^{201}$ Presidents had issued "a multitude of orders extending over a long period of time, and affecting vast bodies of land, ... [and t] hese orders were known to Congress, as principal, and in not a single instance was the act of the agent disapproved." 202 If Congress had objected to the withdrawals, it would not have allowed these "unauthorized acts . . . to be so often repeated as to crystallize into regular practice." 203 Inaction by Congress had therefore raised the presumption that "the withdrawals had been made in pursuance of its consent or of a recognized administrative power of the Executive in the management of public lands." 204 The Court accordingly concluded that Congress's silence constituted "acquiescence ... equivalent to consent to continue the practice until the power was revoked by some subsequent action by Congress." 205

More than a century after Midwest Oil, congressional acquiescence remains a poorly defined legal concept. We know that a "few scattered examples" of acquiescence that are "anomalies," should not inform a court's interpretation of the Antiquities Act. ${ }^{206}$ But there is no clear test for what constitutes "uniformly and repeatedly acquiesced in the [presidential] practice," for what constitutes sufficient congressional knowledge of presidential actions, or for defining the scope of the powers acquiesced to by Congress.

While Congress repeatedly rejected efforts to delegate broad power to reduce national monuments to the President, Congress did not unequivocally bar Presidents from revising or reducing monuments in the Antiquities Act. Subsequent legislation, however, indicates that Congress intended to limit any implied power to revise national monuments that may have been assumed by the President.

In 1976, Congress enacted the Federal Land Policy and Management Act (FLPMA), ${ }^{207}$ which "so changed the laws and the context within which to interpret withdrawal authority as to render pre-FLPMA presidential practices of little relevance." 208 FLPMA codifies a national policy under which "the Congress exercise $[\mathrm{s}]$ its constitutional authority to withdraw or otherwise designate or dedicate

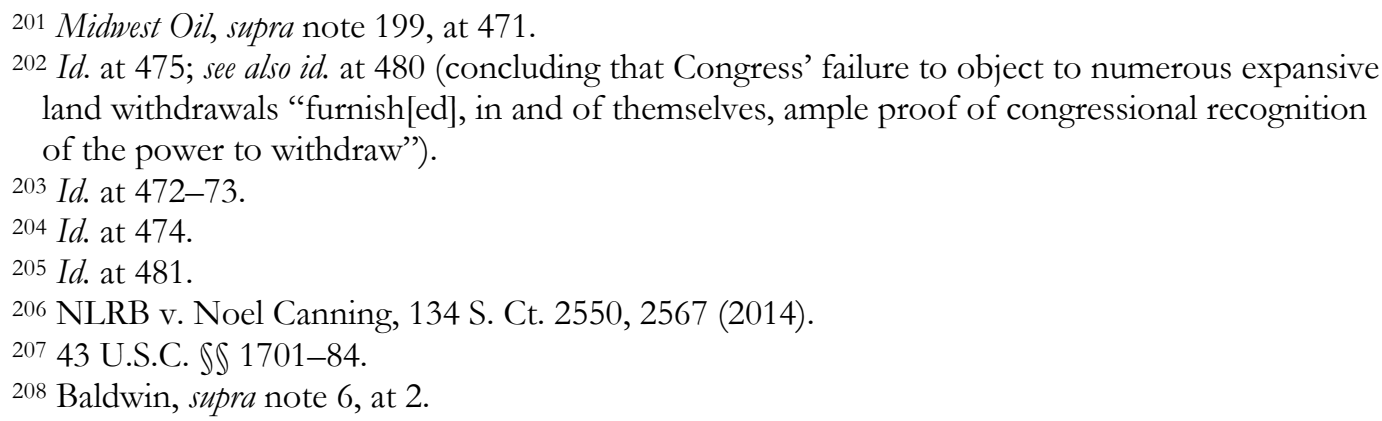


** Pre-Publication Draft **

43 HARVARD ENVTL. L. REV. (2019)

Federal lands for specified purposes and delineate the extent to which the Executive may withdraw lands without legislative actions." 209 In remaking public lands policy, Congress repealed over 300 statutes or parts of statutes involving public lands, ${ }^{210}$ including twenty-nine "statutes or parts of statutes that had provided withdrawal authority to the President." ${ }^{211}$ FLPMA also expressly repealed "the implied authority of the President to make withdrawals and reservations resulting from acquiescence of the Congress." 212 Congress, however, left intact the President's Antiquities Act power to designate national monuments.

Congress also directed that the Secretary of the Interior cannot "modify or revoke any withdrawal creating national monuments," a clear reassertion of congressional authority and limitation on executive branch power. ${ }^{213}$ This provision is however puzzling because the Secretary never had the power to create national monuments, and because denying the Secretary the power to revise decisions that he or she could not make hardly seems necessary. Several public land law professors contend that the provision limits broader executive branch power. ${ }^{214}$ As they point out, committee hearings on early drafts of what would become FLPMA indicate a mistaken belief that the Secretary of the Interior created national monuments, and that some in Congress feared that a future secretary might modify or revoke monuments. ${ }^{215}$ While misunderstandings regarding secretarial authority were resolved, the professors argue that Congress may have failed to update all relevant sections of the statutory text as the bill's authors moved on to other sections of a very long and complex statute. ${ }^{216}$

Alternatively, Congress may have recognized that it had, on occasion, authorized the Secretary of the Interior to modify national monuments. Congress

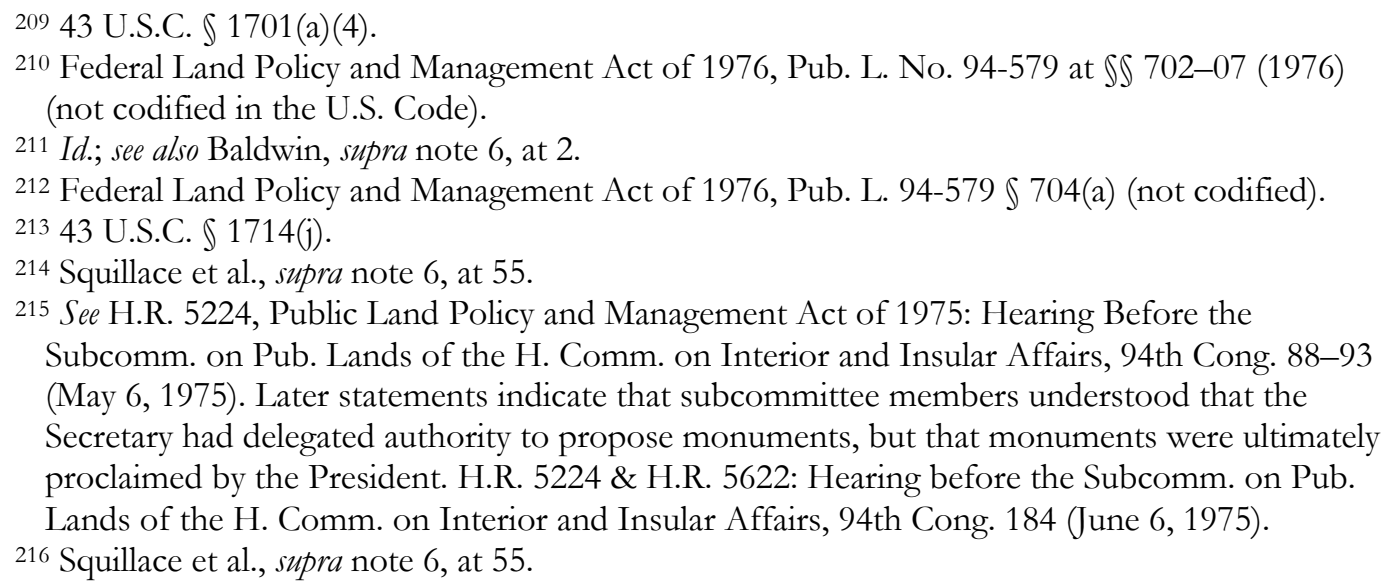


** Pre-Publication Draft **

43 HARVARD ENVTL. L. REV. (2019)

had, for example, authorized the Secretary to "revise the boundaries of the Scotts Bluff National Monument so as to exclude from it certain private and Federal lands and substitute other private lands more essential to the purposes of the monument." ${ }^{217}$ Congress had similarly authorized the Secretary to "adjust and redefine the exterior boundaries" of the Badlands National Monument to "consolidate Federal land ownership therein." 218 Accordingly, Congress may have sought to clarify that no broader grant of power was intended.

Retired Congressional Research Service attorney Pamela Baldwin provides an even more compelling explanation. A 1952 Executive Order conferred on the Secretary of the Interior "all of the delegable authority of the President to make, modify and revoke withdrawals and reservations with respect to lands of the public domain owned and controlled by the United States in the continental United States or Alaska." ${ }^{219}$ Congress may have had concerns regarding the Order's reach while it was debating and drafting FLPMA. Those concerns, while pressing in the leadup to FLPMA's passage, were laid to rest almost three decades later in a challenge to the Grand Staircase-Escalante National Monument when the Federal District Court held that the 1952 Executive Order did not apply to the Antiquities Act. ${ }^{220}$

These readings all comport with the House Committee Report circulated in advance of floor debate about FLPMA. That report states that section 204 "would also specifically reserve to the Congress the authority to modify and revoke withdrawals for national monuments created under the Antiquities Act. ... These provisions will insure that the integrity of the great national resource management systems will remain under the control of the Congress." 221

Plainly, Congress was intent in reining in executive branch power over public lands, and a strong case can be made that Congress intended to reserve to itself the authority to modify and revoke withdrawals for national monuments. A careful review of prior reductions to national monuments also raises serious questions of both the pattern of facts underlying reductions and congressional knowledge regarding prior reductions made by U.S. Presidents.

\footnotetext{
217 Pub. L. No. 87-68, 75 Stat. 148 (1961).

218 Pub. L. No. 82-328, 66 Stat. 65 (1952).

219 Baldwin, supra note 6, at 17 (quoting Exec. Order No. 10,355, 43 C.F.R. IS 2300.0-3 (1952)).

220 Utah Ass'n of Counties v. Bush, 316 F.Supp. 2d 1172, 1195-1200 (D. Utah 2004).

221 H.R. Rep. No. 94-1163, at 9 (May 15, 1976).
} 
** Pre-Publication Draft **

43 HARVARD ENVTL. L. REV. (2019)

\section{Prior Presidential National Monument Reductions and Revisions}

Presidents have reduced national monument boundaries on approximately twenty occasions without congressional objection. Prior revisions went unchallenged by Congress, which may, under Midwest Oil, imply that Congress accepted the President's actions as lawful. But none of these reductions were ever contested in court. Without an opportunity for a court to rule on the propriety of the reductions, their legality remains untested.

Section III reviews the proclamations affecting these prior reductions, correspondence leading up to the reductions, congressional and administrative documents, and scholarly publications discussing the monuments involved in order to better understand the size, scope, and intent undergirding the reductions. Notably, this research unearthed very little congressional discussion of monument reductions, raising a threshold question of whether, as required by Midwest Oil, Congress was sufficiently aware of the reductions to grant its approval. Knowledge of an action is, of course, a prerequisite to acquiescence in its legality. ${ }^{222}$ Additionally, with more than a half-century passing since the last presidential monument reduction, and congressional reassertion of its comprehensive authority over public lands in FLPMA, the President's implied power to reduce a national monument, if it ever existed, may have ebbed away. But if an implied power to reduce a national monument survives, that power should be limited by the scope of what was previously accepted by Congress. Revisions to correct mapping errors and that result in better protection for monument resources, for example, provide little support for revisions intended to increase commodity production by reducing protection for monument resources. Understanding the facts surrounding prior monument reductions is therefore critical to understanding the scope of the President's power to reduce a national monument, if that power indeed exists.

Prior presidential monument reductions fall into three overlapping categories: (1) reductions that were intended to correct errors and omissions in the initial proclamation; (2) reductions responding to new information or changed circumstances; and (3) reductions that were made based on authority other than the Antiquities Act, such as the President's Article II power as Commander in Chief. Together, these three categories reflect changes that were generally intended to enhance or improve management of the objects for which the monuments were proclaimed, and often reflect a determination that those objects would not experience reduced protections.

222 United States v. Midwest Oil Co., 236 U.S. 459, 474 (1915). 
** Pre-Publication Draft **

43 HARVARD ENVTL. L. REV. (2019)

\section{A. Correcting Errors and Omissions in the Original Monument Proclamation}

Until now, every national monument that has been reduced by presidential action was set aside before 1940, and most at least a decade before that. ${ }^{223}$ Maps of the rural West, where all of the reduced monuments are found, were often of poor quality during the early monument designation period, complicating efforts to describe the object to be protected as well as the landscape containing those objects. This frequently resulted in errors in monument boundary descriptions, and also often resulted in inadvertent inclusion of non-federal lands within these federal reserves.

\section{The Recurring Challenge of Public Land Surveys}

The challenges involving public land surveys form an important backdrop for the discussion that follows. Describing accurately the lands included in early national monuments was a recurring challenge for U.S. Presidents. As of 1930, over 50 million acres of public lands had yet to be surveyed, and most of the unsurveyed land was in the West, where all of the revised monuments are located. ${ }^{224}$ Roughly half of the national monument which were revised by Presidents included unsurveyed portions of the public domain. ${ }^{225}$ The lack of formal surveys created significant challenges both in describing the location of the objects to be protected, and in defining monument boundaries. Further complicating matters, surveys that

223 Nat'l Parks Conservation Ass'n, supra note 23.

224 Report of the Committee on the Conservation and Administration of the Public Domain 9 (1931).

225 For examples of national monument proclamations which include unsurveyed lands or maps identifying unsurveyed lands, see Proclamation No. 1875, 46 Stat. 2988 (April 12, 1929)

[hereinafter Arches Proc.]; Proclamation No. 1322, 39 Stat. 1764 (Feb. 11, 1916) [hereinafter Bandelier Proc.]; Proclamation No. 1694, 43 Stat. 1948 (May 2, 1924) [hereinafter Craters of the Moon Proc.]; Proclamation No. 1994, 47 Stat. 2506 (Mar. 17, 1932) [hereinafter Great Sand Dunes Proc.]; Proclamation No. 869, 35 Stat. 2274 (Mar. 2, 1909) [hereinafter Mt. Olympus Proc.]; Proclamation No. 804, 35 Stat. 2183 (Apr. 16, 1908) [hereinafter Natural Bridges Proc.]; and Proclamation No. 1640, 42 Stat. 2285 (Oct. 14, 1922) [hereinafter Timpanogos Proc.]. To get around this problem, some national monument proclamations describe lands in terms of degrees, minutes, and seconds rather than in accordance with the Public Land Survey System. See, e.g., Proclamation No. 1733, 43 Stat. 1988, 1989 (Feb. 26, 1925) [hereinafter Glacier Bay Proc.]; Proclamation No. 1487, 40 Stat. 1855 (Sept. 24, 1918) [hereinafter Katmai Proc.]; and Natural Bridges Proc. 
** Pre-Publication Draft **

43 HARVARD ENVTL. L. REV. (2019)

had been completed prior to monument designation were often riddled with errors. As Paul Gates explained in his seminal 1968 work on public land law:

Many of the surveys were done carelessly, some indeed fraudulently, and were inaccurately marked only by perishable or easily removed corners such as blazes on trees, wooden stakes lightly driven into the soil, or small mounds of earth raked upon the prairie .... [A surveyor working in California reported ' $t$ ] he surveys on the east side of the Santa Clara Valley are wretchedly done. I have yet to find a single survey that measures a mile accurately, and I have yet to find the first corner-stone.' . . . Another California surveyor . . . reported cases where lines were from a quarter to a full mile from meeting . . . . Months or years after the original surveys, when landowners could find no evidence of corners or learned that the lines had been inaccurately run, the Land Office had to order resurveys, sometimes three or four times. ${ }^{226}$

In 1970, the Public Land Law Review Commission recommended "[a]n intensified survey program to locate and mark boundaries of all public lands."227 As the Commission explained:

Erroneous or fraudulent early surveys, as well as impermanent survey markers, which can no longer be located, require substantial resurveys of public land boundaries. There are, for example, as estimated 272,000 miles of boundary between national forests and other ownership. Of these, approximately 253,000 miles need to be established or reestablished. The magnitude of the problem is greater with respect to lands administered by the Bureau of Land Management. $^{228}$

Problems associated with incomplete or inaccurate land surveys continue to plague the BLM, which in 2016 spent $\$ 5.9$ million on surveys associated with land

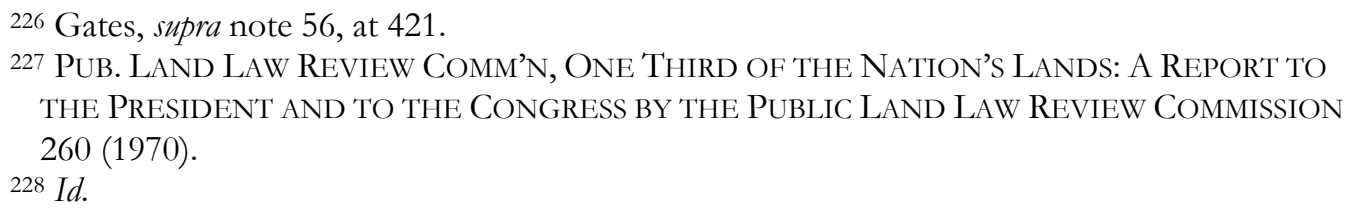


** Pre-Publication Draft **

43 HARVARD ENVTL. L. REV. (2019)

tenure adjustments and to resolve trespass or jurisdictional disputes. ${ }^{229}$

Given that all revised monuments aside from Bears Ears and the Grand Staircase-Escalante were originally proclaimed between 1906 and 1939, it is no wonder that Presidents repeatedly revised national monument proclamations to new reflect information. ${ }^{230}$ Public land surveys were completed for previously unsurveyed regions that included national monuments, poor quality monument boundary surveys were updated, and better information became available regarding both the location of the objects to be protected by national monuments and the landscapes containing those resources. This is not to suggest that revisions made by prior Presidents were necessarily lawful, only that such revisions were needed.

While the need for prior revisions that address mapping issues appears compelling, that justification does little to illuminate President Trump's revisions to either Bears Ears, which was proclaimed in 2016, or the Grand Staircase-Escalante, which was proclaimed in 1996. The proclamations reducing neither of those monument mentions survey errors, which is not surprising given the improvements in mapping quality that occurred over the intervening decades. Reductions of over 1.1 million acres at Bears Ears and over 870,000 acres at the Grand StaircaseEscalante, moreover, can hardly be attributed to mapping error correction. While Congress may have acquiesced in the President's legal authority to revise monument proclamations to correct errors in the original proclamation, prior error correction creates little precedent for recent actions.

\section{Problems Describing the Objects to be Protected and the Landscape Containing Them}

The problems resulting from bad mapping are anything but theoretical. Several early national monuments were set aside in haste, before the specific locations of the objects to be protected were well known. Absent a careful description of the locations of these objects, early proclamations sometimes cast a wide net, protecting a larger geographic area than was intended in order to ensure that objects of historic or scientific interest were not left unprotected. At least twice, Presidents set aside monuments with the express intent of going back and reducing the size of the monument once the precise location of the objects warranting protection had been better identified.

\footnotetext{
229 See Bureau of Land Mgmt., U.S. DeP’T of the Interior, Public Land Statistics 2016, at 35 (2017).

230 See NAT'L Parks CONSERVATiOn Ass'N, supra note 23.
} 
** Pre-Publication Draft **

43 HARVARD ENVTL. L. REV. (2019)

Navajo National Monument, Arizona.

Navajo National Monument, which was set aside by President Taft on March $20,1909,{ }^{231}$ and revised by Taft on March $14,1912,{ }^{232}$ is a case in point. The monument was created to protect large Native American cliff dwellings which were thought to rival those of Mesa Verde. ${ }^{233}$ William Douglass from the General Land Office had been touring the four-corners region and heard rumor of large untouched ruins near Tsegi Canyon, within the Navajo Nation. ${ }^{234}$ Douglass also feared that a professor of classics, untrained in the field of archaeology, was fielding a "pseudoscientific" expedition that would

[M]ake a large collection from the ruins, using untried and poorly trained students. [Douglass] expected the ruins of Tsegi Canyon to be among the last undisturbed ruins discoveries, and in his view, their value to archaeological science was too great to leave to a group interested mainly in collecting artifacts. ${ }^{235}$

Douglass turned to President Taft and the recently-passed Antiquities Act to protect these sites. But Douglass had not yet visited the area and there were no reliable maps locating the ruins. ${ }^{236}$ The best information regarding their location came from the approximation of a Paiute Indian guide. ${ }^{237}$

As a result, [Douglass] arbitrarily requested the reservation of an area even he recognized was far larger than necessary to protect the ruins. Douglass knew that the government had no real way to protect remote places without formal reservation. The large quantity of land was necessary because he had not yet been to the Tsegi Canyon area. But he could not afford to wait, for the party of excavators was on the way. ... The general reservation would suffice as a protective measure until he could visit the area and determine what ought to be

231 Proclamation No. 873, 36 Stat. 2491 (Mar. 20, 1909) [hereinafter Navajo Proc.].

232 Proclamation No. 1186, 37 Stat. 1733 (Mar. 14, 1912) [hereinafter Navajo Revision Proc.].

233 See Hal K. Rothman, NAT’L Park Serv., NAVAjo National Monument: A Place AND

ITS PEOPLE, AN AdMinistrative History 15 (1991).

234 See id. at 18-20.

$235 I d$. at $20-21$.

236 See id.

237 See id. at 19-20. 
** Pre-Publication Draft **

43 HARVARD ENVTL. L. REV. (2019)

in the monument and what could be released to the public domain. ${ }^{238}$

The general reservation that Douglas requested, and that President Taft made, is unlike any other national monument reservation. Not knowing where the cliff dwellings were located, President Taft first defined a general geographic area believed to contain the cliff dwellings. He then reserved as part of the national monument forty acres around every ruin within that larger area. Because the number and location of ruins were unknown, this resulting in an unidentified number of forty-acre sites containing each individual but unidentified cliff dwelling. ${ }^{239}$ Both Douglass and Taft expected to revise the boundary based upon improved surveys, which were published in 1911, ${ }^{240}$ and the next year President Taft rewrote the proclamation to protect three isolated sites that total just 360 acres. $^{241}$ The physical distance between the three isolated monument sites and failure to provide for visitor access or services pose problems for monument administration that continue to this day. ${ }^{242}$

\section{Petrified Forest, Arizona}

Petrified Forest National Monument, now Petrified Forest National Park, had a similar history. As explained in a hearing on a bill to create the National Park Service:

The Petrified Forest National Monument, Arizona, was originally set aside on December 8, 1906, with an area of 60,776 acres. The definite location of the principal deposits of silicified wood was not known, the intention being to reduce the area after the lands could be examined and the location of the valuable deposits determined. During the year Dr. George P. Merrill, head curator of geology, National Museum, visited the reservation at the insistence of this department, and submitted a report thereon recommending the reduction of the metes and bounds of the reservation. ... This report met with the approval of the department, and accordingly, on July 31, 1911, a new proclamation was issued reducing the area of the

\footnotetext{
238 Id. at 21.

239 Navajo Proc., supra note 231.

240 Rothman, supra note 232, at 27.

241 Navajo Revision Proc., supra note 233.

242 RothMAN, supra note 232, at 29.
} 
** Pre-Publication Draft **

43 HARVARD ENVTL. L. REV. (2019)

Petrified Forest National Monument to 25,625 acres. ${ }^{243}$

The Monument was set aside before accurate surveys could be completed because, as the Arizona House of Representatives explained: "Ruthless curiosity seekers are destroying these huge [petrified] trees and logs by blasting them in pieces in search of crystals, which are found in the center of many of them, while carloads of the limbs and smaller pieces are being shipped away to be ground up for various purposes."244 An investigation by the Department of the Interior confirmed the threat to the petrified trees. The Department concluded that "visitors to this region usually carry away with them as much as their means of transportation will permit. ... They usually carry with them some concealed tools or instruments, and with these they are perpetually breaking off pieces of objects of which they wish to carry away as souvenirs." ${ }^{245}$ It was Arizona's wish that "this wonderful deposit should be kept inviolate, that future generations may enjoy its beauties and study one of the most curious and interesting effects of nature's forces."246

While the Merrill survey helped in identifying the objects to be protected, it was imperfect, and the subsequently reduced monument failed to adequately protect the objects identified in the monument proclamation. President Hoover enlarged the Petrified Forest National Monument in 1930 to include an "approach highway and additional features of scenic and scientific interest." ${ }^{247}$ In 1931 he enlarged it again to include additional "features of scenic and scientific interest" as well as lands to be used for access and administrative purposes. ${ }^{248}$ In 1932 he enlarged it a third time to include "certain adjoining lands for administrative purposes and the protection of a certain approach highway and additional features of scenic and scientific interest." 249

243 Establishment of a National Park Service: Hearing on H.R. 22995 Before the Subcomm. on the Public Lands of the H. Comm., 62d Cong. 2d Sess. 32 (1912).

${ }^{244}$ H. Memorial No. 4, 18th Territorial Leg. (Ariz. 1895), as reproduced in LESTER F. WARD, DEP'T OF THE INTERIOR, REPORT ON THE PETRIFIED FORESTS OF ARIZONA 5 (1900).

245 LESTER F. WARD, DEPT. OF THE INTERIOR, REPORT ON THE PETRIFIED FORESTS OF ARIZONA 17-18 (1900).

${ }^{246}$ Id at 5.

247 Proclamation No. 1927, 46 Stat. 3040 (Nov. 14, 1930) [hereinafter 1930 Petrified Forest

Revision Proc.]; Proclamation No. 1975, 47 Stat. 2486 (Nov. 30, 1931) [hereinafter 1931

Petrified Forest Revision Proc.]; Proclamation No. 2011, 47 Stat. 2532 (Sept. 23, 1932)

[hereinafter 1932 Petrified Forest Revision Proc.].

${ }^{250}$ An Act to Authorize the Establishment of the Petrified Forest National Park in the State of Arizona, Pub. L. No 85-358, 72 Stat. 69 (1958)

250 An Act to Authorize the Establishment of the Petrified Forest National Park in the State of 
** Pre-Publication Draft **

43 HARVARD ENVTL. L. REV. (2019)

In 1958, Congress upgraded the monument to National Park status. ${ }^{250}$

\section{Inaccurate and Incomplete Surveys}

\section{Great Sand Dunes, Colorado}

Poor quality surveys of both the objects of scientific or historic interest and the landscape in which those resources existed were a pervasive problem. Presidents revised monument proclamations at least three times because the monuments' legal description were in error. In 1946, for example, President Truman redrew the boundary for the Great Sand Dunes National Monument, reducing it slightly to correct survey errors. ${ }^{251}$ As explained in the proclamation reducing the monument, the boundary to the then fourteen-year-old monument needed correction because:

[T] he lands included within the Great Sand Dunes National

Monument ... were described therein in conformity with plats then on file in the General Land Office and other maps of the locality; . . . resurveys by the General Land Office disclose that [certain lands] . . . described in the said Proclamation, do not exist; and ... it appears necessary and desirable in the public interest to redefine the area included within the Monument in accordance with the latest plats of survey. ${ }^{252}$

Complicating matters, multiple public land surveys converge in the Monument, undoubtedly contributing to survey errors and the need to revise the proclamation. The Monument also included unsurveyed land that were identified in the original proclamation by their "probabl[e]" legal description. ${ }^{253}$

Like the Petrified Forest, Great Sand Dunes was upgraded to a National Park and Preserve. ${ }^{254}$ Today, the Park and Preserve together cover 149,028 acres, or more

\footnotetext{
Arizona, Pub. L. No 85-358, 72 Stat. 69 (1958)

250 An Act to Authorize the Establishment of the Petrified Forest National Park in the State of Arizona, Pub. L. No 85-358, 72 Stat. 69 (1958)

251 Proclamation No. 2681, 11 Fed. Reg. 2623 (Mar. 14, 1946) [hereinafter 1946 Great Sand

Dunes Revision Proc.].

${ }^{252} I d$.

253 See Great Sand Dunes Proc., supra note 225.

254 Great Sand Dunes National Park and Preserve Act of 2000, Pub. L. No. 106-530, 214 Stat. 2527.
} 
** Pre-Publication Draft **

43 HARVARD ENVTL. L. REV. (2019)

than four-times the area set aside in $1932 .{ }^{255}$

\section{Hovenweep, Colorado and Utah}

Hovenweep National Monument, which straddles Utah's southern border with Colorado, was designated in $1923^{256}$ and provides another example of a revision prompted by legal error. Notably, the net effect of the revision was to increase, rather than reduce, resource protection. ${ }^{257}$ President Eisenhower in 1956 revised the monument boundary, eliminating lands that were "erroneously included" in the monument because of a typographical error, and that "contain[ed] no objects of historic or scientific interest." ${ }^{258}$ The lands removed were misidentified in the legal description as the $\underline{\mathbf{S W}} 1 / 4, \mathrm{NE} 1 / 4$ of section 20 , and were replaced by the $\underline{\mathbf{S E}} 1 / 4$, NE1/4 of section 20. Additional lands containing Cutthroat Castle were added to the monument at that time, ${ }^{259}$ reflecting the third enlargement to the monument since its creation.

\section{Timpanogos Cave, Utah}

The 150-acre Timpanogos Cave National Monument provides yet another example. Originally proclaimed in 1922, the location of the cave system proved difficult to describe accurately, in part because the caves were located "upon unsurveyed lands within the Wasatch National Forest." 260 As President Kennedy explained in the proclamation modifying the boundaries:

[A] subsequent survey, accepted by the General Land Office on May 17,1945 , disclosed that that diagram does not accurately depict the boundaries of the monument as those boundaries are marked on the ground; and ... it appears that it would be in the public interest to redefine the external boundaries of the monument in conformity

\footnotetext{
255 Original acreage from National Parks Conservation Ass'n, supra note 23. Current acreage from Listing of Acreage (Summary), supra note 23.

256 See Proclamation No. 1654, 42 Stat. 2299 (Mar. 2, 1923) [hereinafter Hovenweep Proc.].

257 Proclamation No. 2924, 16 Fed. Reg. 3687 (May 1, 1951) [hereinafter 1951 Hovenweep Expansion Proc.]; Proclamation No. 2998, 17 Fed. Reg. 10,715 (Nov. 26, 1952) [hereinafter 1952 Hovenweep Expansion Proc.].

258 See Proclamation No. 3132, 21 Fed. Reg. 2369, 2369 (Apr. 12, 1956) [hereinafter 1956

Hovenweep Revision Proc.].

${ }^{259} \mathrm{Id}$.

260 Timpanogos Proc., supra note 225.
} 
** Pre-Publication Draft **

43 HARVARD ENVTL. L. REV. (2019)

with the survey. ${ }^{261}$

Mount Olympus, Washington

Survey errors at Mount Olympus National Monument created similar confusion, complicating management efforts. As the Secretary of Agriculture explained, "[t] he original diagram accompanying the proclamation dated March 2, 1909 , it appears was not drawn with strict regard for the correct assemblage of the unsurveyed townships, regarding which there was little evidence at that date."262 These problems were resolved in 1915 as part of a boundary revision that is discussed in more detail in Parts III.A.3., and III.C. ${ }^{263}$

Arches, Utah

Updated land and resource surveys also prompted revisions to Arches National Monument. On April 12, 1929, President Hoover proclaimed two areas totaling 4,520 acres that were "located in unsurveyed townships" as Arches National Monument. ${ }^{264}$ On November 25, 1938, President Franklin Roosevelt expanded the monument by 29,160 acres to include lands containing "geologic and prehistoric structures of historic and scientific interest," and "other public lands contiguous to the said monument which are necessary for the proper care, management, and protection of the objects of scientific interest situated on the lands included in the monument and on the other lands referred to above." 265 However, it soon became clear that the boundaries of the enlarged monument would need further adjustment:

[A] considerable portion of the public lands in the western section of the monument was unsurveyed [when the 1938 proclamation expanding Arches National Monument was drafted] . . . . Accordingly, the boundary could not be established on the ground with any degree of certainty, and surveys completed in 1945 revealed that several objects of outstanding scientific and scenic value which

\footnotetext{
261 Proclamation No. 345, 76 Stat. 1457 (Mar. 27,1962) [hereinafter Timpanogos Modification Proc.].

262 Letter from D.F. Houston, Sec. of Agriculture, to the Sec. of the Interior (March 22, 1915) (on file with author).

263 See id.

264 See Arches Proc., supra note 225.

265 Proclamation No. 2312, 53 Stat. 2504, 2504 (Nov. 25, 1938) [hereinafter 1938 Arches Revision Proc.].
} 
** Pre-Publication Draft **

43 HARVARD ENVTL. L. REV. (2019)

were intended to be included in the monument, such as the noted Fiery Furnace area, had been omitted. It was also revealed that adequate provisions had not been made for road access to scenic and scientific features. ${ }^{266}$

The 1945 survey also identified "certain lands lying along the east boundary of the monument that are not of monument significance and could be better utilized for grazing and other purposes." ${ }^{267}$ The federal government began efforts to adjust the monument's boundaries, but efforts to redraw the boundary stalled, as the state of Utah and the federal government attempted to concurrently negotiate an agreement to exchange state lands within the monument expansion area for federal lands outside of the monument. ${ }^{268}$ It was not until 1960, after negotiations were concluded and the matter was resolved, that President Eisenhower trimmed 720 acres from the monument in conjunction with a 480-acre expansion. ${ }^{269}$

\section{Natural Bridges, Utah}

Natural Bridges National Monument provides yet another example of error correction that improved monument management. Natural Bridges was proclaimed by President Roosevelt on April 16, 1908 during the final year of his presidency. ${ }^{270}$ President Taft expanded the Monument a year later because:

[A]t the time this monument was created nothing was known of the location and character of the prehistoric ruins in the vicinity of the bridges, nor of the location of the bridges and the prehistoric cave springs, also hereby reserved, with reference to the public surveys, the same being many miles from surveyed land. ${ }^{271}$

\footnotetext{
266 Letter from Julius A. Krugg, Secretary of the Interior, to President Harry S. Truman, 1 Nov. 17,1949 ) (on file with author).

${ }^{267} \mathrm{Id}$.

268 Memorandum from Director, Bureau of Land Mgmt., to the Director, Nat'l Park Serv., re:

Proposed Proclamation, Arches National Monument, Utah (Dec. 9, 1949) (on file with author). 269 Proclamation No. 3360, 25 Fed Reg. 7145 (July 26, 1960) [hereinafter 1960 Arches Revision

Proc.].

270 Natural Bridges Proc., supra note 225.

271 Proclamation No. 881, 36 Stat. 2502, 2502 (Sept. 25, 1909) [hereinafter 1909 Natural Bridges Revision Proc.].
} 
** Pre-Publication Draft **

43 HARVARD ENVTL. L. REV. (2019)

Seven years later, President Wilson revised the boundary because "the three several [sic] tracts embraced within this monument reservation have been resurveyed and relocated with reference to the recently established corner of the public land surveys, to the end that their location has been definitely fixed." ${ }^{272}$ But President Wilson recognized that challenges describing the monument continued, as portions of the monument remained in "unsurveyed townships." 273

President Kennedy became the fourth President to revise the Monument's boundaries based on improved survey data when, in 1962, he added 5,236-acres ${ }^{274}$ to the Monument to:

Provide a protective strip on the south and west sides of the present monument lands; preserve several cliff-type prehistoric Indian ruins adjacent to the monument on the north; and make available sufficient lands to the east for a headquarters and road network. The existing monument lands are inadequate, not only for planned development, but for protection of the area's prime scientific and scenic values. ${ }^{275}$

He simultaneously trimmed 320 acres from the monument. ${ }^{276}$ According to President Kennedy's 1962 proclamation, the excluded lands "no longer contain features of archeological value and are not needed for the proper care, management, protection, interpretation, and preservation of the monument."277

The lands removed involved two 160-acre "remote detached sections"278 approximately twenty miles from the monument, each of which contained a cave and spring. When the monument was initially designated, "these caves were considered significant primarily because springs in the caves provided the only available water

\footnotetext{
272 Proclamation No. 1323, 39 Stat. 1764, 1764 (Feb. 11, 1916) [hereinafter 1916 Natural Bridges Revision Proc.].

273 Id. at 1765.

274 Proclamation No. 3486, 76 Stat. 1495, 1495-96 (Aug. 14, 1962) [hereinafter 1962 Natural Bridges Revision Proc.].

${ }^{275}$ Letter from John A. Carver, Jr., Acting Ass. Sec. of the Interior to David E. Bell, Director of the Bureau of Budget (June 5,1962) (on file with author).

276 Id.

2771962 Natural Bridges Revision Proc., supra note 274 at 1496.

278 Memorandum from Nusbaum, Archaeologist, to the Regional Director, Region Three, Nat'l Park Serv., Proposed Boundary Adjustment, Natural Bridges National Monument at 1 (Oct. 25,1949 ) (on file with author).
} 
** Pre-Publication Draft **

43 HARVARD ENVTL. L. REV. (2019)

along the route traveled by visitors to the area." ${ }^{, 279}$ However, after about 1925 , the springs were no longer critical for visitors because "[p] rogressive road construction . . eliminated the need for this old trail approach and the watering locations." 280 While one of the caves that was removed from the monument had at one time contained a small pueblo ruin, that ruin had "been completely destroyed by stock watering and seeking shelter at the cave. Archaeologists feel that any archaeological values in these caves have been destroyed." 281

The boundary change was also done in conjunction with a transition from the "natural metes and boundaries" description in the proclamation to the rectangular survey system utilized by the BLM's cadastral engineers. ${ }^{282}$ As explained by the Department of the Interior employees who worked to redefine the monument boundary:

$[\mathrm{W}]$ e bowed to modern survey techniques and stayed with breakdowns of the one square mile section system. Bates was the conservative here, and I was somewhat greedy about taking land away from the BLM for the expansion of Natural Bridges. The final boundaries, after several reviews by the Department of the Interior, NPS, BLM, and state agencies in the early 1960s, came out to a fairly respectable size and protected the monument much better. The new boundaries avoided the possibility of a large hotel dominating the scene overlooking any of the natural bridges by being far enough back from the bridges to provide a good buffer zone. ${ }^{283}$

Maps that failed to accurately represent the landscape containing newly minted national monuments were a major and recurring problem throughout the rural West. These challenges were exacerbated by the limitations inherent in the surveying and mapping technology that was in use a century ago. Reasonable people can disagree on whether Congress' failure to object to these revisions signaled acquiescence in the President's power to revise national monuments to correct mapping and survey errors. A court ruling on the reductions to Bears Ears or the

\footnotetext{
279 Memorandum from National Park Service Director Conrad Wirth, 2 (Jan. 23, 1961) (on file with author); see also Memorandum from Nusbaum, supra note 278, at 1.

280 Memorandum from Nusbaum, supra note 278, at 1.

281 Memorandum from Conrad Wirth, supra note 279, at 2.

282 Lloyd M. Pierson, I Remember Bates, 63 UTAH Hist. Q. 135, 143-44 (1995).

$283 \mathrm{Id}$.
} 
** Pre-Publication Draft **

43 HARVARD ENVTL. L. REV. (2019)

Grand Staircase-Escalante national monuments, however, need not define the outer boundary of that power, or even affirm its existence. Carving the Grand StaircaseEscalante in half and shrinking Bears Ears by eighty-five percent were not, and cannot, be described as error correction.

\section{Inadvertent Inclusion of Non-Federal Land}

Updated surveys revealed new information not only about the objects to be protected and the landscape containing them, but also about non-federal lands and facilities that had inadvertently been included within monument boundaries. The Antiquities Act only authorizes Presidents to designate national monuments "on land owned or controlled by the Federal Government." ${ }^{284}$ Presidents therefore lack authority to designate non-federal lands, including non-federal inholdings, as part of a national monument. Nevertheless, in many instances, updated surveys revealed that non-federal lands and facilities had in fact been included in monuments. In order to remove a potential cloud on the title of private land, Presidents issued new proclamations excluding these lands from the monument. These proclamations should not be thought of as monument reductions, as they merely clarify what the Antiquities Act had already settled.

Boundary adjustments such as these were a system-wide goal of the National Park Service. In 1954 the Chief of Cooperative Activities wrote to the Director of the National Park Service recommending that the Service

re-examine the boundaries of all areas to see if recommendations for modified boundaries might be made to contract present areas and thereby reduce the problem of acquiring inholdings, or to reduce problem management. An active program for the acquisition of inholdings should be adopted with adequate budgetary support where the inholdings materially detract from the full development and enjoyment of the park or monument area. ${ }^{285}$

The Chief then quoted a December 4, 1953 memorandum on reorganization stating that: "Recommendations shall be made periodically as to boundary readjustments and inholding acquisitions. The first of such recommendations should be made as early as is reasonably possible and thereafter as information on the subject becomes

28454 U.S.C. \320301(a) (2012).

285 Memorandum from Chief of Cooperative Activities to NPS Director (March 12, 1954) (on file with author). 
** Pre-Publication Draft **

43 HARVARD ENVTL. L. REV. (2019)

available."286

Boundary adjustments became a tool to help the Park Service improve site management through "Mission 66," the decade-long and congressionally authorized program to improve visitor services beginning in $1956^{287}$ and leading up to the Park Service's fiftieth anniversary in $1966 .{ }^{288}$

\section{Black Canyon of the Gunnison, Colorado}

Black Canyon of the Gunnison National Monument is a case in point. President Hoover set aside the 13,148-acre monument on March 2, 1933, ${ }^{289}$ just two days before leaving office. As with other monuments, "one of the most persistent problems confronting Black Canyon of the Gunnison National Monument involved its boundaries-poorly defined, encompassing in some spots too little land for adequate monument development and protection, in other spots including too many in-holdings. $" 290$

Access to the Monument also posed a significant problem. The number of visitors increased by more than three times between 1946 and $1956,{ }^{291}$ and was expected to double again after the state of Colorado paved the "Black Canyon Highway" (Colorado Highway 347) in 1958 to improve access to the Monument. ${ }^{292}$ Within the monuments, however, tourists continued to encounter gravel roads, and the Park Service sought to make rapid improvements in response. ${ }^{293}$ The Park Service also sought to develop the Monument headquarters area as well as picnic and

$286 \mathrm{Id}$.

287 See NAT'L PARK SERV., U.S. DeP’T OF THE INTERIOR, Mission 66 FOR THE NATiOnAL PARK SYSTEM 10 (1956), available at https://perma.cc/F7FR-RHQY.

288 Id.

289 Proclamation No. 2033, 47 Stat. 2558 (Mar. 2, 1933) [hereinafter Black Canyon of the Gunnison Proc.].

290 Richard G. Beidleman, Administrative History of THE BlaCK CANyON OF THE GUNNISON NATIONAL MONUMENT 139 (1965) (on file with author) (citation omitted).

291 See NAT'L Park SERV., U.S. DeP’T OF THE INTERIOR, Mission 66 FOR BlaCk CANYON OF THE GUNNISON NATIONAL MONUMENT 2 (no date) (on file with author).

292 See Bill Sparks, New Black Canyon Highway Will Help Attract Visitors to Area, MONTROSE DAILY PRESS, Apr. 23, 1958, at 1 (reporting the monument superintendent's prediction that construction of the highway would increase visitors from 43,148 the previous year to over 100,000 during the coming summer months).

293 See National Park Service, DePt. of the Interior, Mission 66 For Black Canyon OF THE GUNNisOn NATIONAL MONumENT 2 (no date) (on file with author); Bill Sparks, Tourists from 13 States Join Local Residents at Dedication, MONTROSE DAILY PRESS, May 26, 1958, at 1. 
** Pre-Publication Draft **

43 HARVARD ENVTL. L. REV. (2019)

campground facilities. ${ }^{294}$ The Monument Superintendent and Park Service staff were under pressure to address Mission 66 objectives before the Park Service's anniversary in 1966. Having little money for the land acquisition needed to improve access and enhance visitor facilities within the Monument, they worked to address the needs of the Monument through a congressionally authorized land exchange, ${ }^{295}$ trading public lands within monument boundaries for private land needed to complete the South Rim road. Exchanges such as these "clear[ed] the way for necessary boundary adjustments and development of the area under the Mission 66 program."296 The Park Service further negotiated with private landowners in the aftermath of the exchange, ${ }^{297}$ and on April 8, 1960, President Eisenhower issued a proclamation removing, from the 13,148-acre Monument, 470 acres that were "no longer required for the proper care, protection, and management of the objects of scientific interest." 298

\section{Mount Olympus, Washington}

Mount Olympus National Monument provides an earlier example of efforts to exclude non-federal inholdings. Mount Olympus, now Olympic National Park, was first protected in 1909. ${ }^{299}$ According to Congressman Humphrey of Washington, President Theodore Roosevelt was in favor of protecting the area but congressional efforts to create a national park had stalled. Congressman Humphrey and Gifford Pinchot ${ }^{300}$ went to the President two days before he left office and reported this

294 See Russell L. Mahan, U.S. Dep't of the Interior, Superintendent's Annual Report Black Canyon of the Gunnison National Monument 1956 Fiscal Year 3 (May 18, 1956) (on file with author).

295 An Act to Authorize the Exchange of Certain Lands at Black Canyon of the Gunnison National Monument, Colorado, and for Other Purposes, Pub. L. No. 85-391, 72 Stat. 102 (1958).

296 Memorandum from Superintendent of Colorado-Black Canyon of the Gunnison National Monuments, Nat'l Park Serv., to Director, Nat'l Park Serv. (May 22, 1957) (on file with author) (emphasis in original omitted).

297 See Memorandum from Supervisory Park Ranger of Black Canyon National Monument, Nat'l Park Serv., to Superintendent of Colorado and Black Canyon National Monuments, Nat'l Park Serv. 2 (Aug. 2, 1958) (on file with author).

298 Proclamation No. 3344, 25 Fed. Reg. 3153, 3153 (Apr. 8, 1960) [hereinafter Black Canyon of the Gunnison Revision Proc.].

299 Mt. Olympus Proc., supra note 225.

300 Gifford Pinchot was the first Chief of the U.S. Forest Service and went on to serve as the Governor of Pennsylvania. 
** Pre-Publication Draft **

43 HARVARD ENVTL. L. REV. (2019)

account of their interaction:

Without waiting for any formal greeting, as soon as he entered he called to me across the room, 'Tell me what you want, Mr.

Humphrey, and I will give it to you. Do not take time to give me details, simply tell me what you wish me to do.' 'I said, 'Mr.

President, I want you to set aside as a National Monument, 750,000

acres in the heart of the Olympic mountains, the main purpose of this is to preserve the elk in the Olympics.' He replied, 'I will do it. Prepare your order and I will sign it.' 'That was the whole transaction. I shook hands with him, wished him success in Africa, and told him goodbye.'301

In their haste to create the Mount Olympus National Monument, the proclamation neglected to mention that the monument was limited to federal lands, but it did recognize "prior valid adverse claims" like homesteads. ${ }^{302}$

This recognition formed the basis for minor reductions to exclude nonfederal land from the monument in subsequent years. Understanding that some homestead claims in Mount Olympus had arisen before the monument was proclaimed only to ripen into legal claims of land title some years later, President Taft trimmed 160 acres from the 639,200-acre monument in 1912, ${ }^{303}$ removing a homestead and "permit[ting] certain claimants to land therein to secure title to the land." ${ }^{304}$ In 1929 President Coolidge also removed a 640-acre section from the

301 Clifford Edwin Roloff, The Mount Olympus National Monument, 25 WASH. HiST. Q. 214, 226 (1934); CARSTEN Lien, OlyMPiC BATTLEGROUND 38 (1991).

302 Mt. Olympus Proc., supra note 225, at 2247. See also Meredith B. Ingham, JR., OlympiC NATIONAL PARK: A STUdy OF CONSERVATION ObJECTIVES RElating to itS

ESTABLISHMENT AND BOUNDARY ADJUSTMENTS 10 (1955). Homestead laws allowed pioneering individuals and families to settle on the land, make improvements to the land, and to secure title to the land once they had demonstrated their occupation and use. Numerous homestead laws existed and are summarized in PAUL W. GATES, supra note 56, at chs. XV and XVIII.

303 Proclamation No. 1191, 37 Stat. 1737 (Apr. 17, 1912) [hereinafter 1912 Olympus Revision Proc.].

304 Reports of the DePt. Of THE INTERIOR FOR the FisCAL YEAR ENDING JunE 30, 1915 1103 (1916). 
** Pre-Publication Draft **

43 HARVARD ENVTL. L. REV. (2019)

monument ${ }^{305}$ to exclude another homestead. ${ }^{306}$ It would later come to light that this second homestead was filed to obtain ownership of a hydroelectric dam site, though no dam was built at this location, which is known as "Goblin's Gate."

\section{Glacier Bay, Alaska}

Revisions to the Glacier Bay National Monument also reflect efforts to expressly exclude homesteads and private land claims by recognizing "all prior valid claims." ${ }^{308}$ Glacier Bay was almost 1.4 million acres when originally designated by Calvin Coolidge in 1925. ${ }^{309}$ President Franklin Roosevelt further expanded the Monument by 904,960 acres in 1939. ${ }^{310}$ This enlargement was based in part on an erroneous understanding that "no private lands would be included within the proposed boundaries." "311 In reality, the monument contained a former saw mill site, ${ }^{312}$ four or five homesteads, ${ }^{313}$ a small salmon cannery, ${ }^{314}$ a fur farm, ${ }^{315}$ and a stand of Sitka spruce that had been withdrawn by the Navy for use in airplane construction. ${ }^{316}$ To address the multiple conflicts arising from this error, President Eisenhower reduced the monument by 24,925 acres in $1955 .{ }^{317}$ The conflicts

305 Proclamation No. 1862, 45 Stat. 2984 (Jan. 7, 1929) [hereinafter 1929 Olympus Revision Proc.].

306 The section removed from the monument contained a homestead. U.S. Surveyor General's Office Field Notes, Homestead Entry Survey No. 52 (received Oct. 2, 1911) (on file with author).

307 Carsten Lien described the reduction as having been done "to permit the construction of a dam on the Elwha River," Carsten Lien, The Olympic Boundary Struggle, 52 THE MOUNTAINEER 18, 22 (1959).

308 Glacier Bay Proc., supra note 225.

${ }^{309} \mathrm{Id}$.

310 Proclamation No. 2330, 53 Stat. 2534 (Apr. 18, 1939) [hereinafter Glacier Bay Expansion Proc.].

311 John M. KaufFman, Glacier Bay National Monument, Alaska: A History of its BOUNDARIES 31 (1954) (quoting Chief of Forestry, J.D. Coffman) (on file with author).

312 Id.

${ }^{313} \mathrm{Id}$. at 17 (quoting the Assistant Director of the Alaska District, U.S. Forest Service).

${ }^{314} I d$. at 18.

$315 \mathrm{Id}$.

316 Id.

317 Proclamation No. 3089, 20 Fed. Reg. 2103, $2104-05$ (Apr. 5, 1955) [hereinafter Glacier Bay Revision Proc.]. President Eisenhower purported to act under authority granted to him by the Antiquities Act as well as by the Timber Culture Act, ch. 561, \24, 26 Stat. 1095, 1103 (1891) and the Appropriations Act of 1898, 30 Stat. 11, 34, 36 (1897). The former authorized the 
** Pre-Publication Draft **

43 HARVARD ENVTL. L. REV. (2019)

included "several homesteads which were patented prior to the enlargement of the monument by the proclamation of April 18, 1939."318

As discussed in more detail later in this article, Glacier Bay also contained a secret military airfield that had been constructed to protect the west coast from possible invasion during World War II. Glacier Bay, like many other monuments discussed in this article, also became a National Park and Preserve, and today encompasses over 3.2 million acres. ${ }^{319}$

\section{Katmai, Alaska}

A similar series of events played out at Katmai National Monument. The Katmai proclamation failed to either limit the monument to federal land or recognize valid existing rights. ${ }^{320}$ Much like homesteaders, miners could stake a claim to mineral-rich federal lands, develop their claim, and secure title to the land. ${ }^{321}$ Also like claims filed under homestead laws, mining claims were often staked many years before the claim was perfected and the claimant secured legal title to the land. ${ }^{322}$ In a rare reduction consummated in an Executive Order rather than a Presidential Proclamation, President Coolidge in 1929 trimmed approximately ten acres from the 1,088,000-acre Katmai National Monument to exclude a mining claim. ${ }^{323}$ The Monument had been proclaimed in 1918, ${ }^{324}$ and as the Executive Order explains and congressional documents confirm, John J. Folstad had filed to mine coal near Takhli

President to create forest reserves while the latter authorized the President to designate or modify such reserves. While these statutes allowed the President to include lands removed from the monument in the Tongass National Forest (they had previously been removed from the forest reserve when the monument was expanded in 1939, see Glacier Bay Expansion Proc., 53 Stat. at 2534-35), neither statute authorized national monument reductions.

318 Glacier Bay Revision Proc., 20 Fed. Reg. at 2103, see also supra note 317. The excluded area included open water and the "small homesteader community of Gustavus." Memorandum in Support of Motion of the U.S. for Partial Summary Judgment on Count IV of the Amended Complaint at 21, Alaska v. United States, 546 U.S. 413 (2006) (No. 128, Original).

319 Alaska National Interests Land Conservation Act, Pub. L. 96-487, \ 202, 94 Stat. 2371, 2382 (1980).

320 See Katmai Proc., supra note 225.

321 Robert W. Swenson, Legal Aspects of Mineral Resources Exploitation, in PAUL W. GATES, supra note 56 , at 772 .

$322 I d$.

323 See Exec. Order No. 3897 (Sept. 5, 1923) (eliminating land from the Katmai National Monument "[i]n view of the prior occupation and development of the tract by John J. Folstad as a coal mine for supplying fuel for local use.").

324 Proclamation No. 1487, 40 Stat. 1855 (Sept. 24, 1918) [hereinafter Katmai Proc.]. 
** Pre-Publication Draft **

43 HARVARD ENVTL. L. REV. (2019)

Bay in 1907, in an area that would come to be protected as part of the monument eleven years later. ${ }^{325}$ Mr. Folstad operated the mine for years, and in 1923, he petitioned the General Land Office for a mine permit. ${ }^{326}$ Rather than issue a permit to accommodate this valid existing use, President Coolidge decided to remove the mine area from the Monument and eliminate the conflict. ${ }^{327}$ Katmai, like so many other monuments, was also elevated to National Park and Preserve status and today encompasses over 4 million acres. ${ }^{328}$

\section{Great Sand Dunes, Colorado}

The 1956 revisions to the Great Sand Dunes National Monument ${ }^{329}$ also appear to fall in this category. ${ }^{330}$ Like other monument proclamations of that era, the original Great Sand Dunes proclamation recognized valid existing rights but did not mention non-federal land. ${ }^{331}$ In 1956, President Eisenhower added land along the east border to the monument, while deleting certain unneeded lands and exchanging

325 Letter to L.R. Glavis from H.K. Love, Special Agent, General Land Office (Jan. 17, 1908) in COMPILATION OF LETTERS, TELEgRAMS, REPORTS AND OTHER DOCUMENTS OFFERED IN EVIDENCE BEFore THE JOINT COMM. OF CONG. TO InVESTIGATE THE DEPT. OF THE INTERIOR AND THE BUREAU OF ForESTRY IN THE COURSE OF THE HEARINGS HELD BY THE COMM. JAN. 26 - MAY 28, 1910 212-13 (1910). See generally, JON M. KAUfMAN, NAT'L PARK

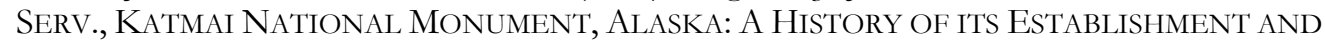
REVISION OF ITS BOUNDARIES 1 (1954) (on file with author) (discussing mining claims that predated monument creation).

326 Frank B. NOrRis, An ERA OF Neglect: Monument Administration Before 1950, in ISOlATED PARADISE: AN ADMINISTRATIVE History OF THE KATMAi AND ANIAKCHAK NATIONAL PARK Units, Alaska (1996) https://perma.cc/MZM6-8T5F.

327 Report of the Director of the National Park Service to the Sec. of the INTERIOR FOR THE FISCAL YEAR ENDING JUNE 30, 1923 AND THE TRAVEL SEASON, 192384 (1923).

328 See Alaska National Interests Land Conservation Act, Pub. L. 96-487, \202, 94 Stat. 2371, 2382 (1980); Park Acreage Report, supra note 23.

329 Proclamation No. 3138, 21 Fed. Reg. 4035 (June 13, 1956) [hereinafter 1956 Great Sand Dunes Modification Proc.]. As with the reduction to Glacier Bay National Monument, President Eisenhower claimed to be acting under authority granted to him in both the Antiquities Act and the Appropriations Act of 1898, 30 Stat. 11, 34, 36 (1897). But the latter act authorized only creation of forest reserves and therefore allowed for inclusion of the removed lands in the national forest without providing additional authority for the reductions.

330 Most early records regarding the Monument were destroyed in a fire, leaving little information about the modification. Telephone Interview with Khaleel Saba, Assistant Archivist, National Park Service Intermountain Region Museum Services Program (May 14, 2018).

331 See Great Sand Dunes Proc., supra note 225. 
** Pre-Publication Draft **

43 HARVARD ENVTL. L. REV. (2019)

them for state and private inholdings within the monument. ${ }^{332}$ "This adjustment accomplished the elimination of several tracts of privately-owned land and makes it possible to accomplish exchanges which will place 4,386 acres of state-owned lands outside of monument boundaries." 333 As the National Park Service Advisory Board explained, "Much of the land to be deleted is State and privately-owned, some has potential mining claims, or mineral leases, and none contains important dunes." The sand dunes, which were unaffected by the revision, were the only objects of historic or scientific importance specifically identified in the proclamation. ${ }^{335}$ The revised boundary, moreover, "retain[ed] about a 2-mile buffer zone for protection of the major dune area." ${ }^{\prime 36}$ Boundary modifications were apparently part of the broader Mission 66 program that resulted in the "most profound period of transformation since Herbert Hoover first authorized the monument in 1932,"337 and which followed earnest pleas for infrastructure upgrades. ${ }^{338}$

\section{Colorado, Colorado}

The 1959 reduction to the Colorado National Monument provides yet another example of the exclusion of private property. Designated on May 24, 1911, the proclamation for the 13,833-acre Monument recognized "prior, valid adverse claims" but did not expressly address non-federal land. ${ }^{339}$ When problems involving non-federal inholdings arose, President Eisenhower, in 1959, trimmed 211 acres from the Monument and added 120 acres to it. ${ }^{340}$ The boundary revision addressed what the National Park Service described as a "complicated land situation" involving

332 See National Park Service Advisory Board Meeting Minutes 15 (Sept. 7-9, 1955) (on file with author). See also, Mission 66 Prospectus, Great Sand Dunes National Monument 16 (1955) (on file with author). Acreages of the monument as well as the reductions at this time are unreliable and inconsistent, likely reflecting the poor quality of existing surveys.

333 Harton L. Bill, National Park Service, Area Management Study Great Sand Dunes National Monument 4 (1956) (on file with author).

334 Sept. 7-9, 1955 National Park Service Advisory Board Meeting Minutes, supra note 332, at 15.

335 See Great Sand Dunes Proc., supra note 225.

336 Sept. 7-9, 1955 National Park Service Advisory Board Meeting Minutes, supra note 332, at 15.

337 Michael M. Geary, SEA of SAND: A History of Great SAND Dunes National Park AND PRESERVE 129 (2016).

338 See Id. at 127 (2016). See also, Mission 66 Prospectus, Great Sand Dunes National Monument 16 (1955) (on file with author).

339 See Proclamation No. 1126, 37 Stat. 1681, 1681 (May 26, 1911) [hereinafter Colorado Proc.].

340 Proclamation No. 3307, 24 Fed. Reg. 6471 (Aug. 7, 1959) [hereinafter Colorado Revision Proc.]. 
** Pre-Publication Draft **

43 HARVARD ENVTL. L. REV. (2019)

undeveloped mining claims, donations to the Park Service that had not been recorded, and six tracts of private land that were all at least partially within the monument. ${ }^{341}$ Together, non-federal inholdings were believed to total 190.36 acres. ${ }^{342}$ Of the 211 acres that were removed, approximately 131 acres reflected lands that had been transferred out of federal ownership in 1911 and 1912, ${ }^{343}$ shortly after the Monument was created. ${ }^{344}$ Both land sales occurred years before the Monument was designated, but a land patent was not issued until after the Monument had been designated. ${ }^{345}$ The excluded parcels were therefore not federal land at the time the Monument was designated and could not have been part of the Monument. National Park Service correspondence also indicates that at least a portion of the excluded lands may have been difficult to manage because, while part of the monument, these lands were outside of the fenced monument area. ${ }^{346}$

\section{Scotts Bluff, Nebraska}

Scotts Bluff National Monument, which lies less than twenty miles east of the Wyoming-Nebraska border, provides yet another example of a monument that was reduced to accommodate existing infrastructure and private land, neither of which were expressly discussed in the original proclamation. Designated in 1919 because of its important role in the history of westward settlement, Scotts Bluff originally included approximately 2,053 acres. ${ }^{347}$ President Coolidge trimmed a quarter-section (160 acres) from the monument in $1924 .^{348}$ The lands eliminated from the monument were "classed as irrigable land under the North Platte Federal

341 Memorandum from P. P. Patraw, Acting Regional Director, to Superintendent, Mesa Verde (March 12, 1953) (on file with author).

${ }^{342} \mathrm{Id}$.

343 U.S. Patent No. 210775 (filed June 22, 1911); U.S. Patent No. 292,293 (filed Sept. 16, 1912)

(both on file with author). Patented lands did not follow monument boundaries. Patented acreage therefore exceeds acreage removed from the monument.

344 Colorado Proc., 37 Stat. 1681 (May 26, 1911).

345 E-mail from Chris Haviland, BLM, to author (Mar. 12, 2018, 14:46 MST) (on file with author).

346 Letter from Homer W. Robinson, Superintendent, Colorado National Monument, to Mr. Ples E. Watson (Apr. 6, 1956) (on file with author).

347 See Proclamation No. 1547, 41 Stat. 1779 (Dec. 12, 1919) [hereinafter Scotts Bluff Proc.].

348 Exec. Order No. 4008 (Calvin Coolidge, May 9, 1924), reproduced in Report of the Director of the National Park Service to the Secretary of the Interior for the Fiscal Year Ended June 30, 1924 and the Travel Season 1924 (1924) (on file with author). 
** Pre-Publication Draft **

43 HARVARD ENVTL. L. REV. (2019)

Irrigation Project and [were] eliminated for that reason."349

The excluded lands were also subject to a homestead that included a "residence, cultivation, and improvements." "350 While the General Land Office accepted proof of homestead development six years after the Monument had been reduced, it appears that homestead development predated the reduction by at least a decade. The Gering Irrigation District was created in 1895, and by 1900 had completed a series of canals that connected it with the existing Mitchell Canal and Irrigation District. Newly constructed canals included " 25 miles of new canal . . . through a very rough stretch of country, locally called 'Bad Lands," that are the Scotts Bluff National Monument. ${ }^{351}$ The Gering Lateral to the Gering Canal cuts the eliminated section roughly in half and connects into the Mitchell and Gering Canal. ${ }^{352}$ While the lands eliminated from the monument were under federal control at the time of the designation, their subsequent transfer out of federal ownership left the federal government without the ownership or control required by the Antiquities Act.

Modern national monument proclamations invariably state that the monument is limited to federal lands, and that the proclamation is subject to valid existing rights. Indeed, both the original Bears Ears and the Grand Staircase-

Escalante national monument proclamations contain such language. ${ }^{353}$ The Trump administration has not claimed that the reductions to these two monuments were undertaken to eliminate non-federal inholdings - which were already expressly excluded from both monuments, should any exist-and the scale of the reductions indicates clearly that they were not tailored to address challenges involving nonfederal inholdings.

White Sands, New Mexico

A similar problem arises with respect to infrastructure, and two revisions to

349 DEP'T OF THE INTERIOR, RePORT OF THE DireCtor OF THE NATIONAL PARK SERVICE TO THE SECRETARY OF THE INTERIOR FOR THE FISCAL YEAR ENDED JUNE 30, 1924 AND THE Travel SEASON 192416 (1924).

350 Letter from D. K. Parrott, Acting Assistant Commiss'r of the General Land Office, to Charles E. Gering (Apr. 2, 1930) (on file with author).

351 Tenth Biennial Report of the State BoArd of IrRigation and Drainage to the GOVERNOR OF NEBRASKA 68-69 (1914).

352 See U.S. Geological Survey, Dept. of the Interior, Scottsbluff South Quadrangle NebraskaScotts Bluff Co. 7.5 Minute Series (Topographic [Map]) (1963).

353 Bears Ears Proc., supra note 3, at 1143, and Grand Staircase-Escalante Proc., supra note 40, at 50,225 . 
** Pre-Publication Draft **

43 HARVARD ENVTL. L. REV. (2019)

national monuments clarified that highways bisecting the landscape before national monuments were designated were, much like homesteads and mines, not intended to be part of the monument. In 1933, President Hoover proclaimed the 134,487-acres White Sands National Monument in New Mexico. ${ }^{354}$ Barely a year later, President Franklin Roosevelt reduced the Monument by 158.91 acres $^{355}$ because "certain sections of the right-of-way for United States Highway Route 70 are included within the White Sands National Monument." ${ }^{356}$ The road that would become Highway 70 predated the Monument, and the proclamation that reduced the Monument merely allowed for improvements to existing infrastructure along the Monument's southeast border. ${ }^{357}$

\section{Craters of the Moon, Idaho}

Craters of the Moon National Monument was similarly revised to facilitate improvements to an existing highway that ran through the Monument. At the time of the initial proclamation in $1924,{ }^{358}$ access to the Monument was from the Idaho Central Highway, which, according to the map appended to the original proclamation, came very close to the northwest border of the Monument. The highway was rerouted through the Monument some time prior to 1928, and the 1928 Monument expansion roughly tripled the length of the highway through the Monument. ${ }^{359}$ Idaho sought to improve that highway, which was graded earth outside the monument and a semi-surfaced road through the monument. ${ }^{360}$ To accommodate highway improvements, President Franklin Roosevelt excluded the highway route from the Monument. ${ }^{361}$ His 1941 proclamation removing the highway

354 Proclamation No. 2025, 47 Stat. 2551 (Jan. 18, 1933) [hereinafter White Sands Proc.];

National Parks Conservation Ass'n, supra note 23.

355 Monuments List, supra note 23.

356 Proclamation No. 2295, 53 Stat. 2465 (Aug. 29, 1938) [hereinafter White Sands Revision Proc.].

357 See New Mexico State Highway Dept., Official Road Map of New Mexico (1932) https://perma.cc/MY25-Y2XB; New Mexico State Highway Dept., Official Road Map of New Mexico (1935) https://perma.cc/55HX-ZLMJ.

358 Craters of the Moon Proc., supra note 225.

${ }^{359}$ Id. See also, Proclamation No. 1843, 45 Stat. 2959 (July 23, 1928) [hereinafter 1928 Craters of the Moon Expansion Proc.].

360 Texaco Touring Service, Texaco Road Map: Idaho, Montana, Wyoming (1937) (on file with author).

361 Proclamation No. 2499, 55 Stat. 1660 (July 18, 1941) [hereinafter Craters of the Moon Modification Proc.]. Idaho Central Highway was once Hwy. 22 and is now Hwy 20 
** Pre-Publication Draft **

43 HARVARD ENVTL. L. REV. (2019)

states that the excluded lands are "not necessary for the proper care and management of the objects of scientific interest situated on the lands within the said monument," implying that the revision did not undermine resource protection. ${ }^{362}$

Revisions such as these highlight an important problem with claims of authority based on congressional acquiescence. Midwest Oil makes clear that the presidential action must be known to Congress. ${ }^{363}$ Minor revisions that corrected typographical errors in a proclamation, resolved technical errors in monument boundary descriptions, or excluded lands not under federal ownership or control from a national monument may not have risen to congressional attention. The burden of demonstrating congressional knowledge falls on the President, and a lack of demonstrable congressional knowledge may limit the number of prior reductions that can be relied upon to demonstrate the requisite pattern of informed congressional acquiescence. And those proclamations that do satisfy the congressional awareness requirement have little in common with the combined 2 million plus acre reductions to Bears Ears and the Grand Staircase-Escalante national monuments.

\section{B. New Information and Changed Conditions}

The need to revise monument boundaries in light of improved information is not surprising given the limitations of early maps and surveys. Over the years, Presidents revised monument boundaries to reflect new information and changed conditions at individual monuments and surrounding landscapes. These revisions generally improved monument access and management, and better protected the objects identified in the original monument proclamations.

\section{Grand Canyon II, Arizona}

One of the largest and most complicated presidential revisions to a national monument involved the Grand Canyon. On January 11, 1908, Theodore Roosevelt set aside the largest monument to that date, the 808,000-acre Grand Canyon National Monument. ${ }^{364}$ Despite its landscape scale, ${ }^{365}$ many believed that the

\footnotetext{
$362 I d$.

363 United States v. Midwest Oil, 236 U.S. 459, 474-75 (1915).

364 Proclamation No. 794, 35 Stat. 2175 (Jan. 11, 1908) [hereinafter Grand Canyon Proc.]. See also

National Parks Conservation Ass'n, supra note 23.

365 The Supreme Court upheld the monument designation, concluding that the Grand Canyon "is an object of unusual scientific interest" within the meaning of the Antiquities Act, effectively resolving whether landscape-scale features could be protected as monuments. Cameron v.
} 
** Pre-Publication Draft **

43 HARVARD ENVTL. L. REV. (2019)

monument was neither large enough to protect the area, nor that the monument designation provided sufficient substantive protections for the area's sensitive resources. ${ }^{366}$ Controversy continued for years regarding how much of the Grand Canyon landscape to protect, and about how to balance protection with logging and grazing.

In 1916, Congress created the National Park Service, ${ }^{367}$ and three years later, Congress converted most of the Grand Canyon National Monument into our country's seventeenth national park. ${ }^{368}$ The congressionally-directed change in status came with a reduction in size that contributed to concerns from the Park Service and others that the Park boundaries "had been drawn too close to the rim of the canyon; did not follow natural features; were difficult to administer as far as wildlife was concerned, [and] did not offer adequate [wildlife] range." 369 As the Park Service subsequently explained, a "park designed to protect a superlative canyon cannot protect it when only one wall of the canyon is within the park." 370 The Park Service had similar concerns regarding wildlife habitat: ${ }^{371}$

As with most of our National parks the Grand Canyon was set aside as a rare physiographic and geological feature of unusual interest and beauty, but with little appreciation of its value as a native wildlife refuge, and zoological laboratory of surpassing interest. ... Still here are to be found some of the most thrilling wild animal exhibits on the Continent and there is every reason to believe that several others of

United States, 252 U.S. 450, 455 (1920) (internal citations omitted).

366 Barbara J. Morehouse, A Place Called Grand Canyon 39-40 (1996).

${ }^{367}$ National Park Service Organic Act, Pub. L. No. 64-235, 39 Stat. 535 (1916) (codified as amended at 16 U.S.C. SS 1-18f).

368 MOREHOUSE, supra note 366, at 44.

369 John M. KaufFman, COnSERvation Objectives at the Grand Canyon: A History OF THE BOUNDARIES OF GRAND CANYON NATIONAL PARK AND GRAND CANYON NATIONAL MONUMENT 4 (1954) [hereinafter History OF THE BOUNDARIES OF GRAND CANYON]. See also, MoreHouse, supra note 366, at 53.

370 Memorandum from H.C. Bryant, Grand Canyon Nat'l Park Superintendent to Reg'l Dir., Region Three 3 (Oct. 1944) (date illegible in copy) (on file with author).

371 Wildlife and the habitat it occupies are objects of scientific interest under the Antiquities Act and therefore appropriate for protection as a national monument. See Cappaert v. U.S., 426 U.S. 128, 142 (1976) ("The pool in Devil's Hole [National Monument] and its rare inhabitants are 'objects of historic or scientific interest,"' and that monument designation to protect them was an appropriate exercise of the Antiquities Act). 
** Pre-Publication Draft **

43 HARVARD ENVTL. L. REV. (2019)

our most important large game mammals and birds of the region can be brought up to an abundance limited only by the carrying capacity of the range. ${ }^{372}$

Others expressed concern that important scenic areas and geologic wonders had been left out of the Park. ${ }^{373}$ Congress responded by approving a 32,000-acre park expansion in 1927, which only partially allayed these concerns. ${ }^{374}$

Debate continued, with multiple proposals to change the park boundary. ${ }^{375}$ According to the Park Service, time was of the essence in resolving the boundary controversy and the area protected needed to be expanded "as soon as possiblebefore railroad indemnity selection rights in the area could be taken up."376 Consequently, in December of 1932, during the waning days of his presidency, Herbert Hoover expanded the protected landscape by proclaiming the 273,145-acre Grand Canyon II National Monument. ${ }^{377}$

But the Grand Canyon II Monument boundary was again an incomplete and imperfect compromise. Incomplete and inaccurate land surveys of the area further complicated matters. ${ }^{378}$ For the next seven and a half years, Congress and the President worked to revise the Monument boundary, and no fewer than nine bills were introduced as part of that effort. ${ }^{379}$ The last of these bills, Senate Bill 6, proposed to cut 148,159 acres from the Monument ${ }^{380}$ and reached the President's desk on August 7, 1939. President Roosevelt vetoed Senate Bill 6, explaining that "he

372 Report of Chief Field Naturalist Dr. Vernon Bailey of the Biological Survey to Chief Paul G. Redington of the Biological Survey, as quoted in HISTORY OF THE BOUNDARIES OF GRAND CANYON supra note 369, at 14-15.

373 MOREHOUSE, supra note 366, at 56.

374 An Act: To revise the boundary of the Grand Canyon National Park in the State of Arizona, Pub. L. No 69-645, 44 Stat. 1238; MoreHOUSE, supra note 366, at 62.

375 MOREHOUSE, supra note 366, at 68.

376 History OF THE BOUNDARIES OF GRAND CANYON, supra note 369, at 19. Railroads received certain enumerated sections of land as compensation for construction of public railroads. Where these sections of lands were subject to homestead or mining claims, or the land had already been conveyed into private ownership, railroads had the right to select replacement lands, which were known as "indemnity" lands.

377 Proclamation No. 2022, 47 Stat. 2547 (Dec. 22, 1932) [hereinafter Grand Canyon II Proc.].

378 S. Rep. No. 76-744, at 3 (1939).

${ }^{379}$ H.R. 12081, 74th Cong. (1936), S. 4503, 74th Cong. (1936), H.R. 7264, 75th Cong. (1937), H.R. 9314, 75th Cong. (1938), S. 3362, 75th Cong. (1938), S. 4047, 75th Cong. (1938), S. 6, 76th Cong. (1939), H.R. 7570, 76th Cong. (1939), and S. 2981, 76th Cong. (1939).

380 S. Rep. No. 76-744, at 2 (1939). 
** Pre-Publication Draft **

43 HARVARD ENVTL. L. REV. (2019)

did not believe there had been sufficient consideration of the matter," and that "[b]efore approving any measure that would eliminate lands from any national monument, I would want to receive a report from representatives of the National Park Service based on a thorough investigation of the land proposed for elimination from the monument." ${ }^{381}$ President Roosevelt then called for a thorough investigation of the Monument boundary. ${ }^{382}$

A preliminary report by Park Naturalist Edwin McKee recommended no change to the southern portion of the Monument, straightening the western boundary to include more antelope habitat, and remarked that the boundary under Senate Bill 6 was "entirely inadequate and eliminated from the monument areas many features which logically belong to it and are of both scientific and scenic importance." "383 McKee went on to note that "a wildlife problem would soon arise" under the congressionally defined boundary and that "no Government representatives connected with drafting of the proposed boundaries of Grand Canyon National Monument has yet visited or studied on the ground [all of] the area in question." ${ }^{384}$ Park Service biologists reached a similar conclusion, opining that "boundary changes should be adjusted for the benefit of antelope and bighorns. If this is done, the remainder of the animal life will be adequately provided for." ${ }^{385}$

A subsequent "full scale study of the boundary question" largely concurred with McKee's recommendations. ${ }^{386}$ In December of 1939, Ben M. Thompson, Chief of the National Park Service Planning Division, transmitted the commission's final report to Secretary of the Interior Harold Ickes, recommending the boundaries that would eventually be codified in a 1940 proclamation. ${ }^{387}$ Secretary Ickes concurred in these boundaries and forwarded to President Roosevelt a proposed proclamation reducing the size of the Monument." "388 As Secretary Ickes explained, "this recommended boundary is drawn to retain the heads of side canyons; to retain the principal volcanic exhibits on the western boundary; to exclude the privately-owned lands for which there is little hope of acquisition and to exclude grazing land that is

\footnotetext{
${ }^{381}$ Franklin D. Roosevelt, Memorandum of Disapproval (Aug. 7, 1939) (on file with author).

382 HiSTORY OF THE BOUNDARIES OF GRAND CANYON, supra note 369, at i.

383 Id. at 23.

384 Id. at 23.

385 W.B. McDougal, Regional Wildlife Technician for the National Park Service Special Report, Proposed Boundary Changes at Grand Canyon National Park 3 (no date) (on file with author). 386 Id. at 24.

387 Id. at 25.

388 MOREHOUSE, supra note 366 at 78.
} 
** Pre-Publication Draft **

43 HARVARD ENVTL. L. REV. (2019)

not essential for Monument purposes." 389

Following these recommendations, President Roosevelt reduced Grand Canyon II on April 4, 1940, trimming 71,854 acres (26-pecent) from the Monument. ${ }^{390}$ Two pending congressional bills ${ }^{391}$ to reduce the Monument were allowed to die, ${ }^{392}$ apparently reflecting congressional assent to the new boundary. "The only surprises, perhaps, are the length of time to reduce the size of the monument and the relatively small amount of territory that opponents won back." ${ }^{393}$

In the lead up to the 1940 revision, Congress and the President worked together to forge a workable compromise, considered nine separate bills to remake the boundary, and the President convened a commission on boundary adjustments. A giant of a President, at the zenith of presidential power, President Franklin Roosevelt finalized what Congress failed to do-and he did so with the knowledge, sustained involvement, and informed consent of Congress.

Notably, on January 20, 1969, President Johnson designated the 32,547-acre Marble Canyon National Monument. ${ }^{394}$ Both the Grand Canyon II and Marble Canyon national monuments were incorporated into Grand Canyon National Park in 1975, protecting approximately 1.2 million additional acres. ${ }^{395}$ President Clinton further expanded protections for the Grand Canyon landscape in 2000, when he designated the 1,014,000-acre Grand Canyon Parashant National Monument. ${ }^{396}$ Today, the lands that were removed by the 1940 proclamation, and then some, are protected.

389 Barbara jo Morehouse, Power Relationships in the Spatial Partitioning and Natural Resource Management of the Grand CANyOn 190 (1993) (unpublished Ph.D. dissertation, University of Arizona) (on file with author). See also, HISTORY OF THE BOUNDARIES OF GRAND CANYON, supra note 369 at 25.

390 Presidential Proc. No. 2393, 54 Stat 2692 (1940) [hereinafter Grand Canyon II Reduction Proc.].

391 S. 2981 (1939) and H.R. 7570 (1939); both were companion bills reflecting the same boundary contained in the earlier 76 S. 6 (1939).

392 History OF THE BOUNDARIES OF GRAND CANYON, supra note 369 at 25.

393 Morehouse, supra note 366 at 68; see also, MOREHOUSE DisSERTATION supra note 389 at 178.

394 Proclamation No. 3889, 34 Fed. Reg. 909 (1969) [hereinafter Marble Canyon Proc.].

395 An Act to Further Protect the Outstanding Scenic, Natural, and Scientific Values of the Grand Canyon by Enlarging the Grand Canyon National Park in the State of Arizona, 88 Stat. 2089, 2090; P.L. 93-620\$3 (1975).

396 Proclamation No. 7265, 65 Fed. Reg. 2825 (2000) [hereinafter Grand Canyon Parashant Proc.]. 
** Pre-Publication Draft **

43 HARVARD ENVTL. L. REV. (2019)

\section{Bandelier, New Mexico}

Prior to President Trump's recent actions, the most recent national monument reduction by a President occurred fifty-five years ago on May 27, 1963, when President Kennedy redrew the boundaries of Bandelier National Monument. ${ }^{397}$ First proclaimed in $1916^{398}$ and later expanded in $1932^{399}$ and again in 1961, ${ }^{400}$ President Kennedy's 1963 revision added to the Monument 2,882 acres of land ${ }^{401}$ that Los Alamos Scientific Laboratory ${ }^{402}$ had agreed to transfer to the National Park Service. In return for its transfer, the Lab received 3,925 acres that previously had been part of the Monument and that "had been fully researched and are not needed to complete the interpretive story of the Bandelier National Monument." 403

The land exchange was the culmination of four years of negotiations, ${ }^{404}$ which added high-value wilderness lands to the Monument, creating an important protective buffer between the growing Los Alamos community and archaeological ruins. ${ }^{405}$ In return, Monument managers relinquished an area that had been severely impacted by unmanaged visitation and that had lost much of its scientific integrity and value. ${ }^{406}$ Notably, the National Park Service was concerned about the lack of resources to manage the sensitive and over-visited archaeologically rich lands that would eventually be excluded from the Monument. ${ }^{407}$ By transferring these lands to the Lab, which was closed to public entry, ${ }^{408}$ the federal government limited public

397 Proclamation No. 3539, 28 Fed. Reg. 5407 (June 1, 1963) [hereinafter 1963 Bandelier Revision Proc.].

398 Bandelier Proc., supra note 225.

399 Proclamation No. 1991, 47 Stat. 2503 (Feb. 25, 1932) [hereinafter 1932 Bandelier Revision Proc.].

400 Proclamation No. 3388, 26 Fed. Reg. 247 (Jan. 11, 1961) [hereinafter 1961 Bandelier Revision Proc.].

4011963 Bandelier Revision Proc., supra note 397, at 5407.

402 Los Alamos Scientific Laboratory is now the Los Alamos National Laboratory.

403 Id.; see also Michael Kelleher, Changing Approaches to Management at the Tsankawi Mesa of Bandelier

National Monument, 20 The GeOrge Wright Forum 58, 62 (2003) (discussing the land exchange).

405 See Hal Rothman, Bandelier National Monument: An Administrative History, S.W. CULTURAL

ResourCes Center Professional PAPERS No. 14, 48-52 (1988).

406 See id. at 48.

407 See id. at $51-52$.

408 See U.S. Dept. of Energy, Draft Environmental Impact Statement for the Conveyance and

Transfer of Certain Land Tracts Administered by the Department of Energy and Located at 
** Pre-Publication Draft **

43 HARVARD ENVTL. L. REV. (2019)

access to sensitive sites and increased protection for the objects of historic and scientific and historic interest identified in the original proclamation. ${ }^{409}$

\section{Wupatki, Arizona}

Revisions to the Wupatki National Monument do not fit neatly into any category but, like other revisions discussed in this section, appear intended to advance resource stewardship without harming the objects identified for protection in the original monument proclamation. President Franklin Roosevelt trimmed 52.27 acres from the 35,865-acre Wupatki National Monument on January 22, 1941 to enable construction and operation of a water diversion on the Little Colorado River, and to facilitate the irrigation of lands on the Navajo Indian Reservation. ${ }^{410}$

Two points are notable about the Wupatki reduction: First, unlike most other presidential monument reductions where Presidents claimed only to be acting in accordance with the Antiquities Act, President Roosevelt also claimed authority ${ }^{411}$ to shrink the Monument arising from the Pickett Act. ${ }^{412}$ This claim of authority, however, appears misplaced. The Pickett Act, passed in 1910, authorized a President to temporarily reserve public lands for "water-power sites, irrigation, classification of lands, or other public purposes to be specified in the orders of withdrawals, and such withdrawals or reservations shall remain in force until revoked by him or by an Act of Congress." 413 The Pickett Act provides little authority for the reduction since the Monument was not originally set aside under the Pickett Act. ${ }^{414}$ While the Pickett Act empowered the President to revise temporary reservations proclaimed thereunder, it did not authorize the President to eliminate reservations designated in accordance with other laws. It did, however, empower the President to reserve the water project

Los Alamos National Laboratory, Los Alamos and Santa Fe Counties, New Mexico 13-1

(1999) (explaining that Technical Area 74, which includes most of the land transferred to the Lab, is gated and "access to the tract is currently limited to Federal, State, and local government personnel on official business.”).

409 See id.

410 Proclamation No. 3454, 55 Stat. 1608 (Jan. 22, 1941) [hereinafter Wupatki Modification

Proc.]. The monument had been proclaimed sixteen years earlier. See Proclamation No. 1721, 43 Stat. 1977 (Dec.9, 1924) [hereinafter Wupatki Proc].

411 See Wupatki Modification Proc., supra note 410, at 1608.

412 Pub. L. No. 61-303, 36 Stat. 847 (1910) as amended by Pub. L. No. 62-316, 37 Stat. 497 (1912) (repealed 1976).

413 Id. at 847.

414 See Wupatki Proc., supra note 410, at 1977 (noting that the President is acting under authority granted by the Antiquities Act of 1906). 
** Pre-Publication Draft **

43 HARVARD ENVTL. L. REV. (2019)

site from disposal pursuant to other laws once the lands involved were removed from the Monument.

Second, the proposal to reduce the Monument was originally made by the Navajo Service and was approved by the Commissioner of Indian Affairs ${ }^{415}$ before being routed to the Park Service for its approval, and eventually sent on to the President. The National Park Service, which administered the monument, did not object to the project because:

The weir seems to be proposed for diversion purposes only; [and] would not be expected to impound and thus back up any appreciable quantity of water. The diversion canal is entirely on reservation lands. We would be affected only in that one abutment of the weir would be against that bank of the river which constitutes our boundary. ${ }^{416}$

The Wupatki National Monument custodian also carefully surveyed the area and concluded that no major archaeological sites would be impacted. ${ }^{417}$

President Trump's recent actions are distinguishable from these revisions as his reductions do not appear to reflect new information about either the objects to be protected or the landscape containing those resources. They also do nothing to enhance resource protection.

\section{National Monument Boundary Revisions Under the President's Article II Power}

Article II of the U.S. Constitution sets forth the powers of the President. These powers include that of Commander in Chief of the military "when called into the actual Service of the United States." 418 While no President has formally claimed to reduce a national monument based on his power as Commander in Chief, the facts show that the existential threats to the United States posed by World War I and

\footnotetext{
415 See Letter from E.R. Fryer, General Superintendent, Navajo Service, to Commissioner of Indian Affairs (July 12, 1940) (on file with author).

416 Letter from Hugh M. Miller, Superintendent of Southwest Monuments, Nat'l Park Serv., to

David J. Jones, Custodian of Wupatki National Monument, Nat'l Park Serv. (Aug. 21, 1940) (on file with author).

417 See Letter from David J. Jones, Custodian of Wupatki National Monument, Nat'l Park Serv., to Hugh M. Miller, Superintendent of Southwest Monuments, Nat'l Park Serv. (Sept. 13, 1940) (on file with author).

${ }^{418}$ U.S. CONST. art. II, $₫ 2$, cl. 1.
} 
** Pre-Publication Draft **

43 HARVARD ENVTL. L. REV. (2019)

World War II were front and center in three decisions to revise national monument boundaries. There also appears to be little doubt that the President's Article II powers were recognized as potentially authorizing monument reductions. Writing on the eve of World War II, the Secretary of the Interior opined that:

Should national defense exigencies arise requiring the use of any specific areas within the national park system [which, at that time, included all national monuments] which are nowhere else available, the President of the United States, as Commander in Chief of the armed forces of the United States, would have plenary power to take all steps necessary for national defense. ${ }^{419}$

\section{Santa Rosa Island, Florida}

Revisions to the Santa Rosa Island National Monument during 1945 were directly linked to national security. World War II broke out in 1941, and shortly thereafter the War Department was directed to take over management of about 384,000 acres of land on Santa Rosa island that had previously been managed by the Choctawhatchee National Forest, with the purpose of expanding Eglin Field. ${ }^{420}$ The Air Force recounts that "Eglin became the site for gunnery training for Army Air Force fighter pilots, as well as a major testing center for aircraft, equipment, and tactics. In March 1942, the base served as one of the sites for Lieutenant Colonel Jimmy Doolittle to prepare his B-25 crews for their raid against Tokyo." ${ }^{421}$

Three years later, on August 13, 1945, President Truman cut 4,700-acres from the Monument, permanently reserving the land for use by the War Department. ${ }^{422}$ As the proclamation explained, "certain Government-owned lands now comprising a part of the Santa Rosa Island National Monument . . . are needed by the War Department for military purposes; and . . . elimination of such lands from the national monument would not seriously interfere with its administration." 423 The

${ }^{419}$ Letter from Sec'y of the Interior to Hon. Alva B. Adams, Chairman of the Senate Comm. on Public Lands and Surveys, in Minutes of the Thirteenth Meeting of the Advisory Board of National Parks, Historic Sites, Buildings, and Monuments, Oct. 28-30, 1940 (on file with author).

420 See Eglin Air Force Base History, Eglin Air Force BASE, U.S. Air ForCE, https://perma.cc/CPQ8-A42U.

${ }^{421} \mathrm{Id}$.

422 Proclamation No. 2659, 59 Stat. 877, 877 (Aug. 13, 1945) [hereinafter Santa Rosa Reduction Proc.].

${ }^{423} \mathrm{Id}$. 
** Pre-Publication Draft **

43 HARVARD ENVTL. L. REV. (2019)

land was used to expand Eglin Field, which went on to become a cornerstone of our nation's armament development and defense training system. ${ }^{424}$ In 1946, Congress abolished what was left of the original Santa Rosa National Monument, turning the land over to the state of Florida. ${ }^{425}$

\section{Glacier Bay, Alaska}

The reduction of Glacier Bay National Monument can be traced to its use as a military base in World War II. On April 24, 1943, President Franklin Roosevelt issued an Executive Order delegating the President's authority to "withdraw or reserve" public lands ${ }^{426}$ to the Secretary of Interior. Pursuant to that authority, Abe Fortas, who was Acting Secretary of the Interior and who would later go on to become a Supreme Court Justice, issued a secret order ${ }^{427}$ allowing the War Department to temporarily use lands within the Glacier Bay National Monument for national defense purposes so long as those lands and facilities were needed to prosecute World War II. ${ }^{428}$ With war raging in the Pacific and growing fear of a possible Japanese attack, ${ }^{429}$ the War Department constructed an airfield and installed associated infrastructure within the Monument. Following the conclusion of World War II, President Eisenhower removed from the Monument lands that were "now being used as an airfield for national-defense purposes and are no longer suitable for national-monument purposes. ${ }^{, 430}$ While President Eisenhower's reduction was not responding to an immediate threat to the nation, the reduction was a recognition of changes made in response to wartime needs.

424 National Park Service, Dept, of the Interior, Eglin Field Historic District www.nps.gov/articles/eglin-field-historic-district.htm (Last updated: August 29, 2017).

${ }^{425}$ An Act to Abolish the Santa Rosa Island National Monument and to Provide for the Conveyance to Escambia County, State of Florida, of That Portion of Santa Rosa Island Which is Under the Jurisdiction of the Department of the Interior, Pub. L. No. 79-564, 60 Stat. 712 (1946).

${ }^{426}$ Exec. Order No. 9337, 8 Fed. Reg. 5516, 5516 (Apr. 24, 1943)

427 Public Land Order 177, 11 Fed. Reg. 8367 (Aug. 2, 1946).

428 See id. at 8367-68.

429 These fears were well founded. The Japanese bombed Unalaska and Amaknak Islands on June 3, 1942, and occupied Kiska and Attu islands until they were repelled by the U.S. Army in 1943. See Aleutian World War II, NAT'L PARK SERV., https://perma.cc/W764-ZHUH.

430 Proclamation No. 3089, 20 Fed. Reg. 2103, 2103 (March 31, 1955) [hereinafter Glacier Bay Modification Proc.]. As discussed above, reductions also removed private inholdings from the monument. 
** Pre-Publication Draft **

43 HARVARD ENVTL. L. REV. (2019)

\section{Mount Olympus, Washington}

Mount Olympus National Monument in Washington State was also modified to correct errors in the original proclamation and to accommodate national security interests. President Theodore Roosevelt's original proclamation establishing the monument ${ }^{431}$ stated that the area identified is "hereby reserved from all forms of appropriation under the public land laws, subject to all prior valid adverse claims, and set apart as a National Monument." ${ }^{432}$ However, this language conflicted with a later provision in the same proclamation stating that:

The reservation made by this proclamation is not intended to prevent the use of the lands for forest purposes under the proclamations establishing the Olympic National Forest, but the two reservations shall both be effective on the land withdrawn, but the National Monument hereby established shall be the dominant reservation and any use of the land which interferes with its preservation or protection as a National Monument is hereby forbidden. ${ }^{433}$

Loggers sought to harvest the old growth forests within the monument, arguing that the term "forest purposes," should be interpreted to include logging. Mineral prospectors also sought to stake claim to copper and other precious metals they believed were locked up inside the monument. ${ }^{434}$ However, they were thwarted by the Secretary of the Interior who interpreted the national monument reservation as controlling over the national forest reservation and determined that there could be no logging and "no 'prospecting for or working of mineral deposits' in the

431 Proclamation No. 869, 35 Stat. 2247 (Mar. 2, 1909) [hereinafter Olympus Proc.].

432 Id. at 2247.

433 Id. at 2248.

434 See e.g., Asahel Curtis et al., Concerning Legislation, With a View of Changing the Character of the Mt. Olympus National Monument and the creation of the Olympus National Park (1912) (on file with author) resolution, adopted by several local chambers of commerce, advocating that mining be permitted within the Mount Olympus National Monument and Olympus National Park). It appears that these claims were likely a ruse to secure title to valuable timber lands and that little if any valuable minerals were actually present. See

See Memorandum from H.S. Graves, Chief, U.S. Forest Serv., to Francis G. Caffey, Solicitor, Dep't of Agric. 3 (Nov. 12,1914) (on file with author) ("It is certain that many prospectors will be disappointed in the mining values [and] I am deeply concerned at the prospect[ of . . f fake mining claims on our heaviest and most valuable bodies of timber."). 
** Pre-Publication Draft **

43 HARVARD ENVTL. L. REV. (2019)

monument." ${ }^{435}$ Conflict erupted, and commodity producers sought to return as much of the monument as possible to the national forest system, where it could be logged and mined with relative impunity. Other lands would be included in a new National Park. ${ }^{436}$

World War I, which began in 1914, quickly brought the conflict over timber and minerals to a head. Fighting severely reduced timber harvests in Europe, and the need for Douglas fir for ships and Sitka spruce for airplanes became particularly acute. ${ }^{437}$ Sitka spruce was critical to airplane construction because it was light, strong, and did not splinter when struck by a bullet. ${ }^{438}$ Spruce, however, was available only in temperate rainforests like those found along the Pacific Northwest coast, and the Monument was home to "the largest stands of Sitka spruce in the Northwest."

On May 11, 1915, less than a year after the assassination of Archduke Ferdinand and the beginning of World War I and "on the basis of military needs for timber and minerals," ${ }^{40}$ President Wilson cut 299,370 acres from the Monument's original 608,640 acres. ${ }^{441}$ The lands eliminated thereby were returned to the Olympic

435 LIEN, supra note 301, at 39 (quoting Richard Ballinger, Secretary of Interior).

436 See Letter from H.S. Graves, Chief, U.S. Forest Serv., to David F. Houston, Sec'y of Agric. 2 (Dec. 10, 1914) (on file with author).

437 See Notes of Henry S. Graves, Chief, U.S. Forest Serv., 3 (no date) (on file with Yale University Library Archives) ("10. French and British were both short. Our first need had to be at a sacrifice to their convenience and comfort of troops."); id. at 11 ("37. One of the difficult problems was the production of materials for aircraft. 38. Best species Sitka Spruce. Allies had been taking our chief output."). Mr. Graves was the Chief of the U.S. Forest Service from 1910 to 1920 .

438 See Gerald W. Williams, The Spruce Production Division, FOREST HiSTORY TODAY 3 (Spring 1999) (quoting Brice P. Disque, Brigadier General of the U.S. Army); see also GAIL E.H. EvANS \& Gerald W. Williams, Over Here, Over Here: The Army’s Spruce Production Division During “The WAR TO END AlL WARS” 4 (1984).

439 Gail E.H. Evans, Historic Resource Study: Olympic NAtional Park Washington, ch. III (1983) https://perma.cc/LPS3-GBD9.

440 Meredith B. Ingham, Jr. Olympic National Park: A Study of Conservation

OBJECTIVES RELATING TO ITS ESTABLISHMENT AND BOUNDARY ADJUSTMENTS 4 (1955); see

also, GAIL E. EvAns, supra note 439, at ch. III; Elmo R. Richardson, Olympic National Park: 20

Years of Controversy, 12 FOREST HiSTORY NEWSLETTER 6, 7 (1968).

441 Proclamation No. 1293, 39 Stat. 1726, 1726 (May 11, 1915) [hereinafter 1915 Mt. Olympus Modification Proc.]; Monuments List, supra note 23. 
** Pre-Publication Draft **

43 HARVARD ENVTL. L. REV. (2019)

National Forest in order to "permit their development," 442 making much needed lumber available to support the war effort. ${ }^{443}$ In its bid to increase the supply of lumber, the United States went so far as to mobilize the "Spruce Production Division" of the U.S. Army to the Olympic Peninsula to put down labor unrest, and to construct railroads for transporting logs to mills. ${ }^{444}$ This construction is considered to be "among the greatest World War I engineering and labor efforts engaged in by the United States." 445

Critically, a 1935 Solicitor's Opinion discusses the 1915 reduction and states that President Wilson acted only after the Department of Agriculture investigated the boundary change and concluded that the reduction would not impact elk summer range or glaciers - the resources that the monument was set aside to protect. ${ }^{446}$ Glaciers and elk summer range were located at higher elevations that were less desirable for timber production, and these areas would remain protected by the reduced Monument. The Chief of the Forest Service was, however, concerned that reductions could open important elk breeding areas to mining and homesteading, and that even small homesteads "might seriously affect the perpetuation of the animals." ${ }^{447}$ In responding to this concern, the Solicitor assured the Chief that the Secretary of Agriculture would have the authority to refuse to make agricultural land within the proposed elimination area available for homesteading where, in his judgement, "they were chiefly valuable as a breeding ground for elk." ${ }^{448}$ Based on this assessment, the Chief concluded that elk breeding areas could be adequately

442 RePORTS OF THE DEPARTMENT OF THE INTERIOR FOR THE FISCAL YEAR ENDING JUNE 30, 1915, at 1103 (1916).

443 See Evans \& Williams, supra note 438, at 4; ("[T] he Pacific Northwest was the primary supplier of aircraft-quality wood to Great Britain, France and Italy."); see also LIEN, supra note 301, at 219; Williams, supra note 438, at 9.

444 See Williams supra note 438 at 6-7; Evans \& Williams, supra note 438, at 6.

445 Evans, supra note 439, at ch. III.

446 Opinion of the Solicitor, Dept. of the Interior, M. 27657, at 6 (Jan. 30, 1935). Although the original monument proclamation also referred to the elk's "breeding grounds," Mount Olympus Proc., supra note 225 at 2247, the Department did not address possible impacts to the breeding habitat.

${ }^{447}$ Letter from Henry S. Graves, Chief, U.S. Forest Serv., to Francis G. Caffey, Solicitor, Dep't of Agric. 2 (Nov. 12, 1914) (on file with author).

${ }^{448}$ Letter from Francis G. Caffey, Solicitor, Dep't of Agric., to Henry S. Graves, Chief, U.S. Forest Serv. 5-6 (Nov. 30, 1914) (on file with author). This issue arose because the Act of June 11, 1906 empowered the Secretary of Agriculture to open national forest lands to homesteading. Pub. L. No. 59-220, 34 Stat. 233 (1906). 
** Pre-Publication Draft **

43 HARVARD ENVTL. L. REV. (2019)

protected without the monument designation and that the reduced monument "will, in my judgement, provide the essential protection to the elk, substantially as well as under the present arrangement." "449 The state of Washington, moreover, had imposed a ban on all elk hunting in the region through 1925, and all involved appeared to believe that the state would continue to act in ways that would protect the elk. ${ }^{450}$

Twenty years after victory in World War I, Mount Olympus National Monument was re-designated as Olympic National Park, and management was transferred from the U.S. Forest Service to the National Park Service. ${ }^{451}$ With the onset of World War II, interest in commercial access to timber within the newly created park increased again, but the heightened protections afforded to national parks, ${ }^{452}$ and increasing use of aluminum for aircraft construction, were enough to foreclose further intrusions into the park. ${ }^{453}$ Today, Olympic National Park spans 922,560-acres, including most if not all of the areas previously removed from the park

Notably, the reductions to both Santa Rosa Island and Glacier Bay were made following a congressional declaration of war, ${ }^{454}$ when the President's claim to constitutionally granted power as Commander in Chief was at its strongest. ${ }^{455}$ While the 1915 reduction to Mt. Olympus National Monument preceded a declaration of war, it occurred on the heels of two attacks on American-flagged ships and just four days after the German navy sank the British passenger ship the Lusitania, killing more than 1,100 passengers and crew, including 124 Americans. ${ }^{456}$

${ }^{449}$ Letter from Henry S. Graves, Chief, U.S. Forest Serv., to David F. Houston, Sec'y of Agric. 3 (Dec. 10, 1914) (on file with author).

${ }^{450}$ Letter from R.L. Fromme, Forest Supervisor, to the District Forester 3 (Aug. 7, 1914) (on file with author). Protection of elk populations was an important issue because, "[i]n an operation as ruthless as the slaughter of the buffalo of the Great Plains, [elk] hide and teeth hunters moved into the area and killed most of the herd." LIEN, supra note 301, at 32-34.

451 See An Act to Establish the Olympic National Park, in the State of Washington, and for Other Purposes, Pub. L. No. 75-778, 52 Stat. 1241-42 (1938).

452 See National Park Service Organic Act, Pub. L. No. 64-235, 39 Stat. 535 (1916) (codified as amended at 16 U.S.C. $\left.\int 1\right)$.

453 See Janet A. McDonnell, World War II: Defending Park V alues and Resources, 29 THE PUBLIC HistORIAN 15,30-31 (2007).

454 See Joint Resolution Declaring that a State of War Exists Between the Government of Germany and the Government of the People of the United States and Making Provisions to Prosecute the Same, 55 Stat. 796 (1941).

455 See U.S. Const. art. II, \ 2.

456 Telegram from Woodrow Wilson, President of the United States to Ambassador James Gerard (May 13, 1915) https://perma.cc/QA2S-JFER. 
** Pre-Publication Draft **

43 HARVARD ENVTL. L. REV. (2019)

Actions intended to advance our national defense and taken following either a declaration of war or direct and repeated attacks on our nation may have relied on the President's Article II power as Commander in Chief rather than authority delegated by Congress in the Antiquities Act. Furthermore, even if actions were taken under Antiquities Act authority, the pattern of congressional deference to a President during times of war coupled with clear congressional knowledge of the President's broader efforts to protect national security indicate that the President's Article II power was at its zenith when he took these actions.

But revisions related to two World Wars have little relevance today, when no connection between national defense and the reductions to Bears Ears or the Grand Staircase-Escalante national monuments have been provided.

A case can be made that in the past, Congress may have acquiesced in a President's actions to update national monument boundaries that corrected errors and omissions resulting from incomplete or inaccurate boundary surveys, to improve protection of the resources identified in monument proclamations based on new information and changed conditions, to clarify that private lands or infrastructure that predated the monument's creation were not part of the monument, or in response to the existential threat posed by two World Wars. But that has limited precedential value for the contemporary actions. The total number of prior monument revisions made by prior Presidents, less than twenty in total, falls far short of the 252 actions identified in Midwest Oil — and whether Congress was aware of many of those revisions, and thereby able to give its ascent, is unclear. Whether any implied power that may have inured to the President has survived more than a half-century of non-use and the passage of FLPMA is also an open question.

Implied authority to shrink national monuments, if it exists at all, appears to create little cover for President Trump's massive monument reductions. Where other Presidents revised monuments to protect resources or address existential threats to national security, President Trump baldly substituted his "energy first" policy agenda for the preservation objectives underpinning the Antiquities Act and prior monument designations.

Only two prior reductions appear to have any similarity to President Trump's reductions to Bears Ears and the Grand Staircase-Escalante: the reductions to Mt. Olympus and the Grand Canyon II national monuments. While both of those monuments were controversial due in part to their size and the extractive uses they displaced, both are distinguishable. Both early monuments suffered from poor quality mapping that compromised both resource protection and management efficiency. Mt. Olympus was reduced in 1915 only after years of debate, an 
** Pre-Publication Draft **

43 HARVARD ENVTL. L. REV. (2019)

evaluation that the reductions would not impair the objects for which the monuments were protected, and in the face of an existential threat to world peace. Reductions at Grand Canyon II proceeded only after years of effort, sustained congressional involvement, numerous studies, and a careful drawing of a boundary that at least appears to have improved resource protection and monument management. And both monuments are now National Parks that include most, if not all, of the previously removed lands.

In contrast, Bears Ears was reduced by eighty-five percent before its first birthday. Lands released from the monument were opened to mining and drilling and denied the protections previously afforded them as part of the National Landscape Conservation System. Tens of thousands of objects of historic and scientific importance on over 1.1 million acres-more than twice the area of all prior presidential monument reductions combined-lost important protections, and they lost those protections without a searching analysis. No credible claim can be made that the reduction advanced the Antiquities Act's goal of protecting lands and objects that are valuable to culture, history, and science; and the proclamation reducing the monument does not even pretend that decisions were based on national security concerns.

While the Grand Staircase-Escalante survived longer, it too fell to reductions less than a year into the Trump Administration. That hardly seems like enough time to conduct the searching analysis for multiple national monuments and to ensure that the objects for which the monument was designated were protected. Clearly, they were not.

\section{Conclusion}

The Property Clause of the U.S. Constitution grants Congress the power to create, revise or even eliminate national monuments. The Constitution, however, grants no such power to the President, who must rely instead on the authority delegated to him by Congress. The Antiquities Act empowers Presidents to create national monuments, but it does not expressly grant the President the power to revise or eliminate them, and there is little to suggest that Congress intended to grant the President such powers. First, there was no functional need for swift action to reduce national monuments, so Congress had no reason to grant the President such powers. Second, Congress granted Presidents the power to revise other public land reservations when they believed a two-way power was necessary and appropriate, but they chose not to do so in the Antiquities Act. Congress' choice to use different language should be given effect. Third, where Congress allowed the President to 
** Pre-Publication Draft **

43 HARVARD ENVTL. L. REV. (2019)

revise monument boundaries, Congress did so narrowly, in response to monumentspecific needs that did not leave thousands of resources without the protections afforded to national monuments. Congress, moreover, repeatedly rejected legislation granting the President broad revisionary powers, indicating both that Congress understood the President to lack such powers and that Congress intended to retain the power to reduce for themselves.

Although Presidents have reduced national monuments before, the legality of these reductions has never been tested in court and therefore cannot be assumed. While an argument may be made that congressional acquiescence in prior monument reductions endows the President with such powers, the passing of more than a halfcentury since the last reduction also implies that such powers, if they existed, may have withered on the vine. Congress, moreover, forcefully reasserted its authority over the public domain when it enacted FLPMA, repealing an implied grant of the power to the executive branch to reserve land and limiting that branch's power to modify national monuments. But if any power to revise national monuments somehow survived, it must be limited by the scope of prior congressional acquiescence. That acquiescence was limited to correcting errors in the description of the objects being protected and their surrounding landscape, responding to new information or changed conditions in ways that enhance protection for the objects identified in the monument proclamation, excluding from a monument private land and infrastructure that predated the monument's designation, and responding the existential threats to national security such as those posed by two World Wars. There is simply no precedent for President Trump's reductions. Claims of congressional acquiescence cannot be used to justify that which is unprecedented.

Reasonable people can disagree about the wisdom of individual monument designations or whether the Antiquities Act, which is more than a century old, adequately reflects contemporary values. Those seeking redress for perceived injury are not without a remedy, but that remedy resides in the Halls of Congress which unquestionably has the power to create, modify, or even revoke national monument designations. There is no reason to expand the power of the President by creating implied powers that are supported neither by history nor law. 